\title{
Heritage and Participation: a case study of advocacy in post- earthquake Christchurch
}

\author{
Rebecca Margaret Halliday Ford \\ A dissertation submitted in partial fulfilment of the requirements for the degree \\ of Master of Museum and Heritage Studies
}

Victoria University of Wellington

June 2018 



\section{$\underline{\text { Abstract }}$}

This dissertation explores the advocacy for the Christchurch Town Hall that occurred in 2012-2015 after the Canterbury Earthquakes. It frames this advocacy as an instance of collective-action community participation in a heritage decision, and explores the types of heritage values it expressed, particularly social values. The analysis contextualises the advocacy in post-quake Christchurch, and considers its relationship with other developments in local politics, heritage advocacy, and urban activism. In doing so, this dissertation considers how collective action operates as a form of public participation, and the practical implications for understanding and recognising social value.

This research draws on studies of practices that underpin social value recognition in formal heritage management. Social value is held by communities outside institutions. Engaging with communities enables institutions to explore the values of specific places, and to realise the potential of activating local connections with heritage places. Such projects can be seen as participatory practices. However, these processes require skills and resources, and may not be appropriate for all places, communities and institutions. However, literature has understudied collective action as a form of community participation in heritage management. All participation processes have nuances of communities, processes, and context, and this dissertation analyses these in one case.

The research specifically asked what heritage values (especially social values) were expressed through collective action, what the relationship was with the participation processes, communities, and wider situation that produced them, and the impact on institutional rhetoric and decisions. The research analysed values expressed in representations made to council in support of the Town Hall. It also used documentary sources and interviews with key informants to analyse the advocacy and decision-making processes and their relationships with the wider context and other grassroots activities. The analysis concluded that the values expressed intertwined social and professional values. They were related to the communities and circumstance that produced them, as an advocacy campaign for a civic heritage building from a Western architectural tradition. The advocacy value arguments were one of several factors that impacted the decision. They have had a lasting impact on rhetoric around the Town Hall, as was a heritage-making practice in its own right.

This dissertation makes a number of contributions to the discussion of social value and community in heritage. It suggests connections between advocacy and participation 
perspectives in heritage. It recommends consideration of nuances of communities, context, and place meanings when using heritage advocacy campaigns as evidence of social value. It adds to the literature on heritage advocacy, and offers a focused analysis of one of many heritage debates that occurred in post-quake Christchurch. Ultimately, it encourages practice to actively integrate social and community values and to develop self-reflexive engagement and valuation processes. Despite inherent challenges, participatory processes offer opportunities to diversify understandings of value, co-produce heritage meanings with communities, and empower citizens in democratic processes around the places they live with and love. 


\section{Acknowledgements}

My thanks go first and foremost to Dr. Jessica Halliday, Barnaby Bennett, and Prof. Ian Lochhead. This dissertation sits entirely on their work, and their generous participation in interviews. Above all, it is thanks to their efforts that I have a Town Hall to come home to.

A massive thank you goes to my supervisor, Dr. Lee Davidson. Lee has been an immeasurable influence, not just in supporting me through this dissertation, but in forming my thinking over the two-and-a-bit years of this degree.

My advisor Anne Cunningham was instrumental in making the Christchurch Town Hall a possible case study, and in shaping this dissertation towards a participatory perspective. My sincere thanks for the encouragement and the extensive phone calls.

A variety of other heritage professionals helped inform this project, by allowing me the time and networks to discuss possible case studies and social value in practice, and by reminding me that 'a good dissertation is a done dissertation.' For expedient data gathering, a particular thanks to Christchurch City Council's official information team, and Parlour's Justine Clark.

My core network through-out this process has been my incredible course-mates. A big shoutout goes to the Museum and Heritage Studies cohorts of 2016, 2017, and 2018. Guys, you'll be thrilled to know you get a corner of the post-grad room back.

This degree would never have been finished without the immeasurable support of my family and flatmates, who deserve to be named and applauded: Andrew C, Andrew F, Becca, Callum, Dad, David, Declan, Hannah, Josh, Kathryn, Mitchell, Morgan (honorary), Scott, and Zoe. A special thank you to Alec for a painstaking proof-read.

My mother, Mary Ann Halliday, deserves something more than 'thank you.' She has cagouled, encouraged, offered constructive feedback, edited, and ultimately set me down this road in the first place. None of it would have been possible without her.

Finally, my utmost love and appreciation to my incredible sister Claire. Claire's contribution has gone beyond editing, design services, printing, house-work, and steadfast insistence that I could, in fact, 'do the thing.' She has been the person consistently available to discuss the issues herein with intelligence and perspective. Words are not enough. 


\section{$\underline{\text { Table of Contents }}$}

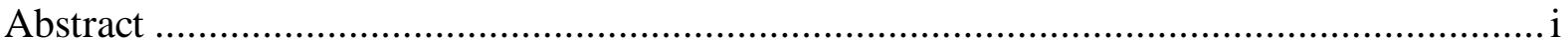

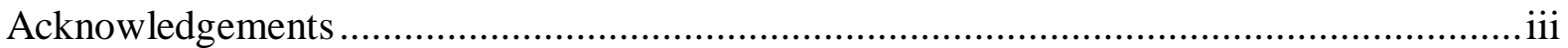

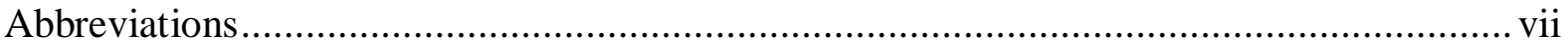

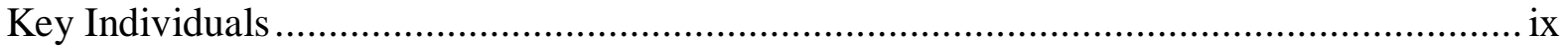

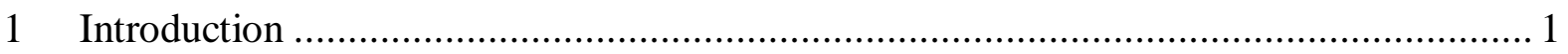

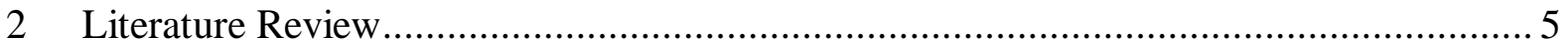

$2.1 \quad$ Critical heritage

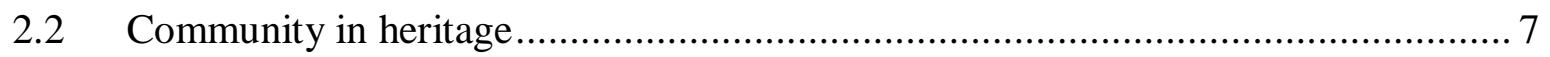

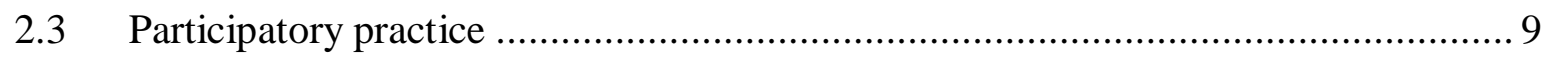

$2.4 \quad$ Formal heritage structures: values and assessments ........................................ 10

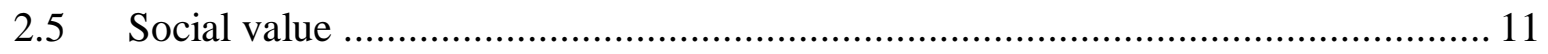

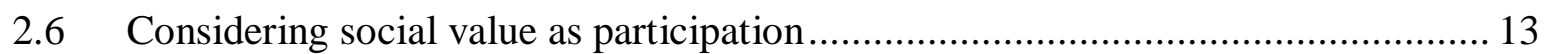

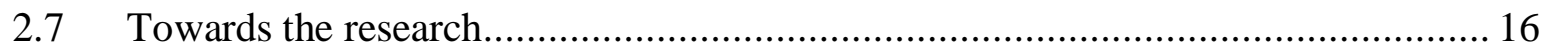

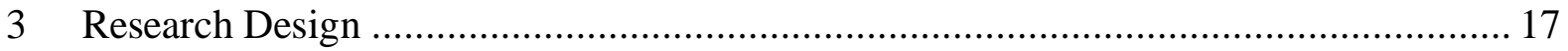

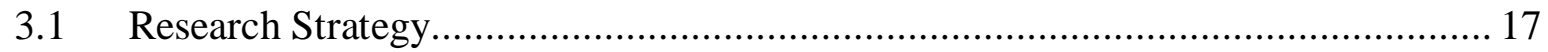

3.2 Heritage campaigns as case studies: strengths and limitations ........................... 20

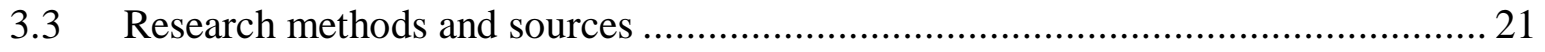

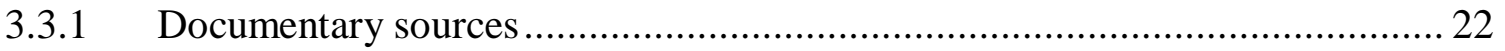

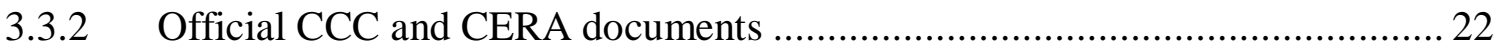

3.3.3 Submissions to CCC Plans ....................................................................... 22

3.3.4 Keep Our Town Hall support letters........................................................ 23

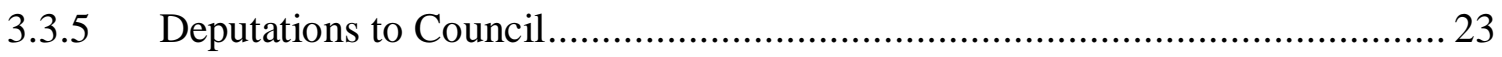

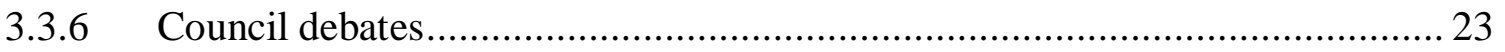

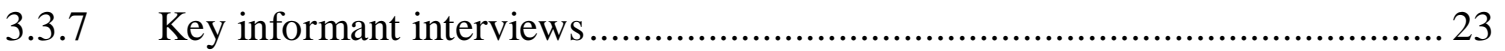

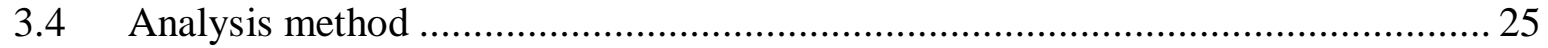

4 Post-quake Christchurch: politics, activism and the built environment...................... 28 


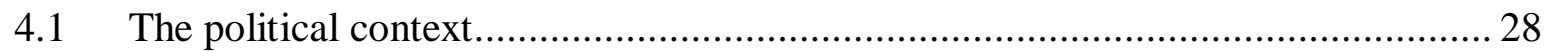

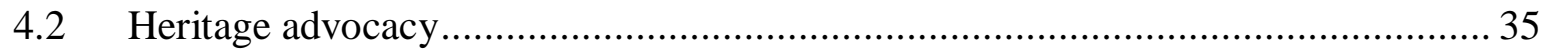

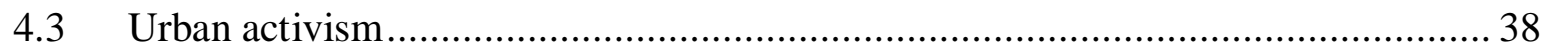

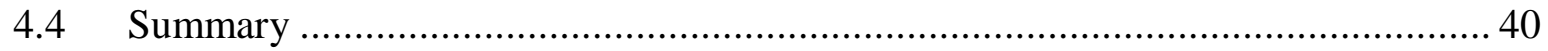

5 The Christchurch Town Hall: Process, opinions, outcomes .................................... 42

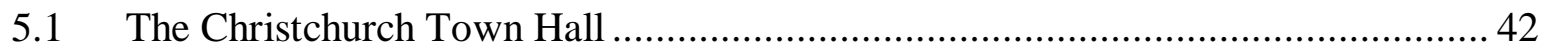

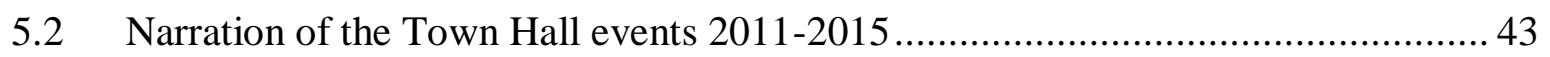

5.2.1 Origins of the Town Hall debate, February 2011 - July 2012 ........................ 44

5.2.2 Up to the first Council Vote, August - November 2012 ............................. 46

5.2.3 Up to the second Council Vote, November 2012 - August 2013 .................... 47

5.2.4 Up to the third Council vote, October 2013 - 11 June 2015 ......................... 49

5.3 Keep Our Town Hall campaign and other Town Hall advocacy.......................... 50

5.4 Advocacy for the Christchurch Town Hall, 2012 - 2015................................ 52

5.4.1 Description of advocacy value expressions..............................................5 52

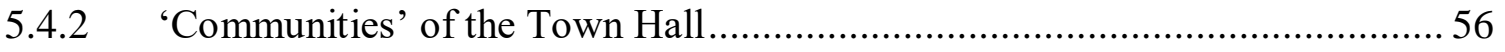

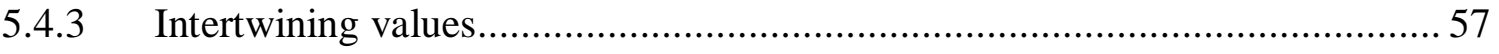

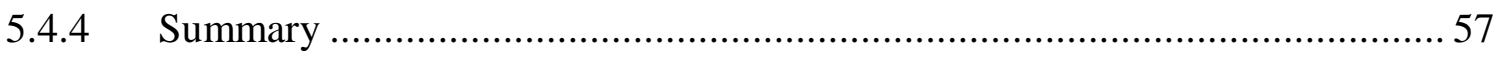

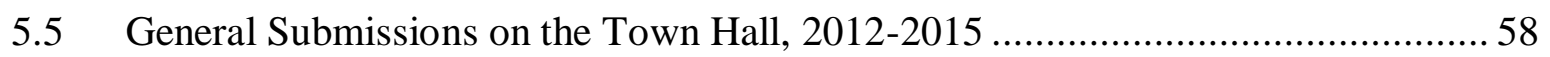

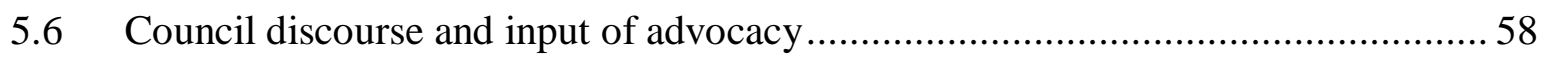

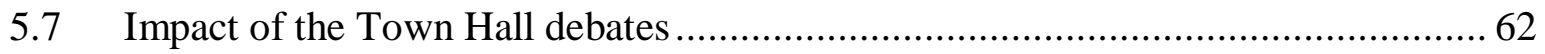

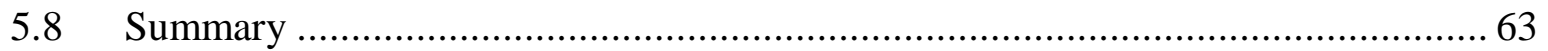

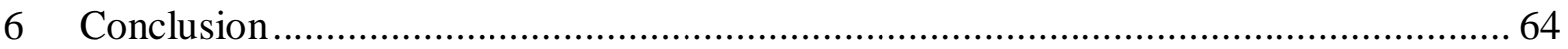

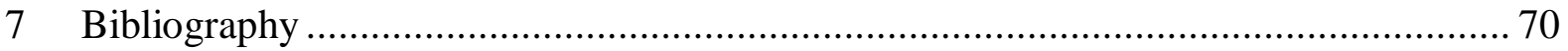

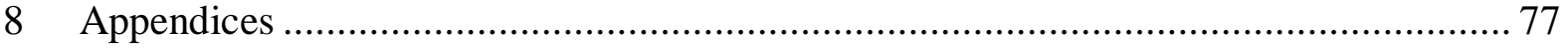

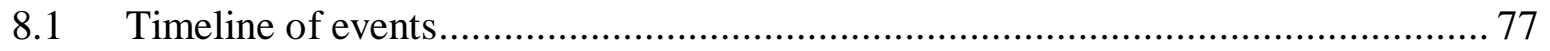

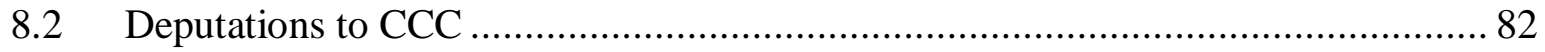

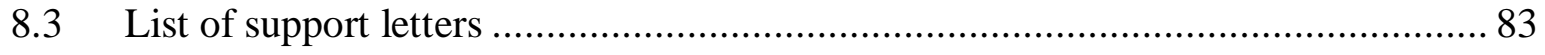


8.4 Submissions to CCC Plans on the Christchurch Town Hall ................................... 87 


\section{$\underline{\text { Abbreviations }}$}

CCC Christchurch City Council.

'Council' is used in reference to sittings Council meetings.

CCDU Central City Development Unit, a sub-unit within CERA.

$\mathrm{CCP} \quad$ Central City Plan

Plan for the rebuild of the central city, produced by CCC in 9 months, used Share and Idea campaign. Technically the 'Central City Recovery Plan', although this is usually used in reference to the CERA 'revision' that superseded it in July 2012.

CCRP Central City Recovery Plan, also known as the 'Blueprint.'

Created by CCDU. Technically a revision of the CCP but generally regarded as a rewriting.

CER Act Christchurch Earthquake Recovery Act.

Written by the Department of the Prime Minister and Cabinet (DPMC).

CERA Christchurch Earthquake Recovery Authority

The central government body with control over Christchurch rebuild.

Reported to the Earthquake Recovery minister, administered the CER

Act.

DOCOMOMO Committee for Documentation and Conservation of Buildings, Sites and Neighbourhoods of the Modern Movement

HNZPT Heritage New Zealand Pouhere Toanga.

This crown entity was the New Zealand Historic Places Trust until 2014.

Referred to as HNZPT throughout, unless directly quoting.

IConIC Interests in Conserving the Identity of Christchurch

A group of advocates for retention of heritage in post-earthquake

Christchurch.

KOTH Keep Our Town Hall

The group of core campaigners who organised in support of the Town

Hall. Note that they never used this acronym themselves.

LGOIA Local Government Official Information Act

OIA Official Information Act

PAP Performing Arts Precinct

Proposed in the CCRP. Never eventuated. 
RDP

URM
Replacement District Plan

A fast-tacked district plan process undertaken by CCC circa 2014.

Unreinforced Masonry 


\section{$\underline{\text { Key Individuals }}$}

\section{CERA/Central Government}

Gerry Brownlee Minister for Earthquake Recovery, Minister of Parliament for Ilam (National Party)

\section{Keep Our Town Hall}

Sir Miles Warren

Pre-eminent New Zealand architect, original designer of the

Christchurch Town Hall, founding partner of Warren and Mahoney architecture firm, ONZ, KBE, Dip.Arch, FNZIA, RIBA

Maurice Mahoney Pre-eminent New Zealand architect, original designer of the Christchurch Town Hall, founding partner of Warren and Mahoney architecture firm, ONZM, FNZIA

Assoc. Prof Dr Ian Professor of Art History at University of Canterbury, specialist in

Lochhead architectural history and history of Christchurch architecture, MA, $\mathrm{PhD}$

Dr Jess Halliday Architectural historian, director of FESTA and Te Pūtahi, PhD

Barnaby Bennett Designer and unregistered architect, B.Arch, BA.

Duncan Craig Christchurch architect, M.Arch.

Sir Harold Marshall Acoustic designer, original designer of the Christchurch Town Hall

\section{Christchurch City Council, 2010-2013}

Bob Parker

Ngaire Button

Claudia Reid

Chrissie Williams

Peter Beck

Glenn Livingstone

Jamie Gough

Sally Buck

Yani Johanson

Tim Carter

Jimmy Chen
Mayor

Deputy Mayor, Shirley/Papanui Ward

Banks Peninsula Ward

Burwood/Pegasus Ward, 2010 - February 2012

Burwood/Pegasus Ward, February 2012 - 2013

Burwood/Pegasus Ward

Fendalton/Waimairi Ward

Fendalton/Waimairi Ward

Hagley/Ferrymead Ward

Hagley/Ferrymead Ward

Riccarton/Wigram Ward 
Helen Broughton Riccarton/Wigram Ward

Aaron Keown $\quad$ Shirley/Papanui Ward

Sue Wells Spreydon/Heathcote Ward

Barry Corbett Spreydon/Heathcote Ward

\section{Christchurch City Council 2013-2016}

$\begin{array}{ll}\text { Lianne Dalziel } & \text { Mayor } \\ \text { Andrew Turner } & \text { Banks Peninsula Ward } \\ \text { Pauline Cotter } & \text { Shirley-Papanui Ward } \\ \text { Ali Jones } & \text { Shirley-Papanui Ward } \\ \text { Jamie Gough } & \text { Fendalton-Waimairi Ward } \\ \text { Raf Manji } & \text { Fendalton-Waimairi Ward } \\ \text { David East } & \text { Burwood-Pegasus Ward } \\ \text { Glenn Livingstone } & \text { Burwood-Pegasus Ward } \\ \text { Vicki Buck } & \text { Riccarton-Wigram Ward } \\ \text { Jimmy Chen } & \text { Riccarton-Wigram Ward } \\ \text { Yani Johanson } & \text { Hagley-Ferrymead Ward } \\ \text { Paul Lonsdale } & \text { Hagley-Ferrymead Ward } \\ \text { Phil Clearwater } & \text { Spreydon-Heathcote Ward } \\ \text { Tim Scandrett } & \text { Spreydon-Heathcote Ward }\end{array}$




\section{Introduction}

This dissertation explores collective action as a form of participation in articulating values of built heritage - particularly social values - and impacting institutional heritage management. It does this through the case and context of advocacy for saving the Christchurch Town Hall after the Canterbury Earthquakes.

The route to this research was particularly serpentine. I was interested in social value as a way to represent contemporary personal and collective connections to a place, and in social research (including ethnographic techniques) as a means of articulating this. Social values are the meanings and associations that a community holds for a place; specifically, they create a collective identity for a community. Academic literature gave me insight into the position of social value in institutions and methods being developed to assess social value from the community. I set out to investigate how these techniques might be applied in a New Zealand context, and particularly how they might influence decision-making and future practice.

An analysis of social value policy did not appeal, as the literature suggested that assessment processes, rather than policy frameworks, are integral to the position of social value and communities in heritage management. There was little discussion of the impact social value could impact on intuitional decisions pertaining to the physical care of a place or building, rather than a listing decision. To that end, a case-study was an appropriate research method.

However, I found it difficult to develop a clear idea of how social value features in New Zealand heritage management. This is partially because formal heritage management is fragmented across a number of organisations, including Heritage New Zealand (HNZPT), the Department of Conservation (DOC), and local authorities such as city and district councils. Cursory investigation showed that there are no consistent values frameworks across New Zealand heritage management, and 'social value' is inconsistently categorised. It also seemed that heritage projects that addressed what I would call social value, or which facilitated community participation in listing and conservation processes, were infrequent or low profile. I also noticed that heritage listings identified 'social value' in a historic sense, such as by referencing heritage advocacy campaigns. I encountered difficulties in discussing 'social value' with heritage professionals, showing that their practice-based understanding of the topic was at odds with my theory-based conceptions. I became increasingly aware that many decisions are not made within frameworks of heritage value, but within wider contexts of political, economic, and emotional influence. 
The difficulties in finding a desirable research method led me to broaden my approach. Further engagement with the literature expanded my thinking about complexities of 'community' as a notion, and 'participation' as a term for interaction between communities and institutions. Participation literature from outside heritage studies allowed me to frame collective action as a form of participation. This meant that I was able to consider heritage advocacy as a form of participation, a perspective that appears to be missing from the literature. The process of finding a good research approach and developing my understanding of the literature led me to consider heritage advocacy as a form of participation in a heritage decision. I was interested in the values expressed, especially social value, and how it impacted institutional perspectives. I came to frame community participation as a heritagemaking process, which (re)formed meanings, associations, and connections with the place. Post-quake Christchurch seemed a prime place to study the relationship between heritage, place and community participation. The Canterbury Earthquakes of 2010-2011 were seminal events with ongoing impacts for Christchurch and the country. Seismic risk became an issue for heritage across the country, leading to challenges of balancing subsequent building law changes and public perception with conservation and heritage issues. Christchurch saw conflicting reactions to heritage loss. It also became a site for innovative grassroots projects in using temporary and participatory practices, which I have labelled 'urban activism'.

The Christchurch Town Hall became the key case-study because it represents an intersection of those practices. From 2011-2015 it was the object of a persistent, articulate advocacy campaign for complete restoration. Key advocates were also closely involved in urban activism projects. An aspect of the case-study was investigating connections between the heritage-focused and contemporary-focused practices of a few key individuals.

This dissertation investigates the advocacy campaign in the context of post-quake Christchurch, particularly focusing on the types of values articulated during the advocacy, and by who. It also briefly considers whether other heritage advocacy could be considered participatory, and whether some of the urban activism practices could be considered heritage practices.

This research builds on previous work on social value and community participation. There has been much written on heritage advocacy and on community participation in social value articulation. This dissertation aims to create a new perspective by considering an instance of heritage advocacy as a form of participation though a social-value framework. In doing so, it 
presents a number of comparisons with examples from the literature that help illuminate the potential benefits and costs of community-focused social value. It also offers a reconsideration of social value relating to a specific urban, Western, architectural heritage building. This case-study also presents a consideration of the wider context of participation action in post-quake Christchurch, which may be useful for future approaches to heritage advocacy, and heritage in a post-disaster environment.

The challenges of this research resulted in a number of lessons which future researchers in a similar position may be able to learn from. These are discussed over the course of the research design and in the conclusion.

I brought a number of preconceptions to this project. I understood that heritage conversation institutions grew out of, and responded to, grassroots heritage movements. On this basis, I conceptualised the ideal role of heritage agencies as advocating for heritage so that communities don't have to wage a battle if their heritage is threatened. This supported the idea that heritage agencies need to have, first: solid, up-to-date understandings of what heritage is important to communities, so they can focus their efforts and respond when necessary; and second: strong evidence of why the heritage place is so important - hence why heritage places should be assessed and listed before they are threatened. I also thought of heritage decisions as being made primarily on the basis of heritage matters, particularly influenced by values-based conservation, as championed by English Heritage (2013). I also thought of legal heritage protections as being somewhat automatic, if weaker and less effective than a heritage professional may wish. Finally, during heritage theory courses and the literature review for this dissertation, I approached formal and non-formal heritage as a strict dichotomy. The literature did not present it as such; rather, my thinking slid in that direction. Whilst my research did not focus on these preconceptions, they were confronted over the analysis of the case study, as discussed in the conclusion.

This dissertation presents a literature review in chapter 2 , which outlines ideas about heritage, community, and participation. It presents the paradigm of heritage values as a notion and a management framework, and assessments as the process that code meaning into values frameworks. It then discusses social value as a concept, and considers a number of casestudies in literature that see social value as intertwined with forms of community participation. This leads into the research questions, presented in research design in chapter 3. This chapter discusses the search for a case-study in greater length, and gives the particulars 
of the Town Hall case-study. This chapter also discusses the research method, data sources, and analysis approach.

Chapter 4 discusses the context of post-quake Christchurch. The three main aspects of this were the political context, heritage advocacy, and urban activism projects. The political context was characterised by central government control of local affairs, with minimal public participation in many normally democratic processes. Grassroots heritage advocacy responded to significant built fabric loss, particularly in the central city, and was largely a frustrated effort. In a different vein, urban activism including temporary and participatory projects became one of the 'good news' post-quake stories, as a number of projects aimed to create a fun and exciting environment in the post-quake landscape, both responding to existing meanings and creating new ones. These illustrate responses to both the loss and opportunity of post-quake Christchurch. On their own, these topics contribute minor points of discussions on heritage meanings and participation. Their main value is the connections between them and the Town Hall advocacy. This dissertation focuses on a few key informants who were each involved in several of these aspects. Considering this wider context allows for consideration of connections between their perspectives and practices, which allow for deeper consideration of heritage advocacy as collective action, and the values articulated by it.

Chapter 5 presents the analysis of the Town Hall advocacy. It presents a narrative of the relevant events in order to better contextualise the significance of the advocacy and decisions. It then discusses the development and strategy of the Keep Our Town Hall (KOTH) group. A focus for this chapter is the analysis of the values expressed in the advocacy by this group and other advocates. The chapter also considers submissions made through the general city council planning processes, which offer a different perspective on the Town Hall. The rhetoric used by councillors in their final debate is also analysed in order to consider the impact of the advocacy.

Chapter 6 presents the conclusions for this research. It primarily addresses the key research questions. It also presents some findings tangential to the main question, offers some suggestions for future research, discusses a few of the limitations of the research, and considers implications for practice. 


\section{Literature Review}

This literature review sets up the research questions within the context of heritage theory and practice. First, a number of concepts are laid out. These are: heritage as a critical field of enquiry; community as a constructed notion; participation as a paradigm for institutional interaction with communities; and heritage values, frameworks and assessments as tools for understanding and managing heritage. These ideas are then brought together in discussing social value. Social value is a category of value that is inherently held by communities attached to a place. As such, it can be used as an avenue for community participation in intuitional processes of articulating and making heritage values. This discussion uses a number of international institution- and academia-driven cases to consider how they may be framed as participatory approaches. The literature review concludes by framing collective action as participation, which then leads into the research questions.

The scope and level of this research means that it is not possible to fully consider the wide and nuanced literature on 'community' and 'participation' even within heritage literature. This literature review instead presents a limited concept of 'community,' which is taken forward into the discussion of social value and participation, and is used in the research analysis.

\subsection{Critical heritage}

'Heritage' refers to social processes through which people and societies relate to their past, thereby forming themselves, their past, and their future. ${ }^{1}$ In other words, heritage is 'a mental construct that attributes 'significance' to certain places, artefacts, and forms of behaviour from the past through processes that are essentially political. ${ }^{2}$ Heritage activities are not merely technical, but a form of cultural politics, a social construct, and a social constructor. Two key dimensions of contemporary (Western) heritage are critical heritage studies, the interdisciplinary field in which this dissertation sets itself, and formal institutional heritage.

Critical heritage studies is the academic field that investigates the production, practice, and impacts of heritage. In examining the processes and impacts underlying the concept of

\footnotetext{
${ }^{1}$ Duncan Light, 'Heritage and Tourism', in The Palgrave Handbook of Contemporary Heritage Research, ed. Emma Waterton and Steve Watson (London: Palgrave Macmillan UK, 2015), 144-58, https://doi.org/10.1057/9781137293565.

${ }^{2}$ William Logan, Ullrich Kockel, and Máiréad Nic Craith, 'The New Heritage Studies: Origins and Evolution, Problems and Prospects', in A Companion to Heritage Studies, ed. William Logan, Máiréad Nic Craith, and Ullrich Kockel (Chichester, West Sussex, UK; Malden, MA: John Wiley \& Sons, Inc., 2016), 1-25, http://catalogimages.wiley.com/images/db/jimages/9781118486665.jpg.
} 
heritage as material things, the historic dichotomy of tangible and intangible heritage is broken down. Critical theory sees everyday actions on heritage objects, buildings, and places as heritage practices, and physical heritage conservation as a heritage meaning-making process. Heritage theory allows heritage professionals to consider the impacts of their practices and structures, and to develop them with new understandings of heritage practices.

The 'discursive turn' in heritage studies has focused on the politics of representation and discursive processes of meaning-making. ${ }^{3}$ Theorists are turning attention back to the role of material things and 'quotidian bodily practices' - our being in the world. ${ }^{4}$ This includes examining ways in which heritage is used in making memory and identity, by individual and various social collectives. Performance, experience, and affect and emotion in heritage have also become key areas of enquiry.

Heritage theorists have closely interrogated the role(s) of 'experts' in constructing and perpetuating current heritage discourses and practices. Formal heritage management occurs on various scales, including national and international, and can have overlapping (sometimes conflicting) jurisdictions and intentions. Systems and frameworks within formal heritage constitute heritage practices, by which people negotiate their relationships with the past (and therefore with their future).$^{5}$ However, these create, preserve, and privilege particular types of heritage, usually based on professional expertise. The different disciplines that have historically dominated heritage management (architecture, history, archaeology) have created biases in conceptions and articulation of heritage. Laurajane Smith critiqued these structures as 'Authorized Heritage Discourse' (AHD). She considered how AHD operates to self-justify and self-normalize, while being expert-driven and material focused. It primarily celebrates monumental physical heritage that upholds existing power structures of class, race, and gender. 6

Recognizing 'authorized' discourses and practices in heritage also recognises that there are alternative discourses and uses of heritage. There is increased acknowledgement of the agency of non-experts or 'lay' people as heritage actors who consume and produce heritage

\footnotetext{
${ }^{3}$ Rodney Harrison, Heritage: Critical Approaches (New York: Routledge, 2013); Zongjie Wu and Song Hou, 'Heritage and Discourse', in The Palgrave Handbook of Contemporary Heritage Research, ed. Emma Waterton and Steve Watson (London: Palgrave Macmillan UK, 2015), https://doi.org/10.1057/9781137293565.

${ }^{4}$ Harrison, Heritage: Critical Approaches.

${ }^{5}$ Harrison.

${ }^{6}$ Laurajane Smith, Uses of Heritage (New York: Routledge, 2006).
} 
for themselves. Dissonant and grassroots heritage practices can both oppose and follow topdown heritage practices. Various studies argue that formal heritage constructions are disconnected from the ways those outside the heritage profession construct, use, and understand their heritage. ${ }^{7}$ This is the theoretical basis for the rise of 'community' as a concern in heritage.

\subsection{Community in heritage}

'Community' is a notion that has become widely, often uncritically, used in the heritage sector, but is increasing examined in literature. ${ }^{8}$ In heritage the term 'community' often homogenises those who are perceived as 'non-expert' or grassroots because they sit outside the heritage profession or fields of expertise. However, communities are never homogeneous - they are multiple and intersecting; created, bound and dispersed by many different factors. Communities are social collectives, possibly self-constructed or constructed by outsiders (including policy makers). As discussed by Elizabeth Crooke, 'When the term 'community' is associated with a group of people ... it is a label that has been created for expediency and purpose. ${ }^{9}$ Communities are defined by cultural markers, which are created by socially engaged groups. Identification and activity in a community seeks personal gain, or responses to threats, hence 'very often, a community emerges as a community of action.'10

Much of the literature discusses communities attached to places, which is why I use the term 'communities of place' to discuss those who identify with a place. In considering the relationship of place and community, a key consideration is which frames the other: does the place precede the communities' identification, or is the community identified and then their place/places considered? In reality, there is a co-forming relationship between collective people and places. It is a widely critiqued issue of the heritage paradigm that places are

\footnotetext{
${ }^{7}$ Smith; Arthur Parkinson, Mark Scott, and Declan Redmond, 'Competing Discourses of Built Heritage: Lay Values in Irish Conservation Planning', International Journal of Heritage Studies, 2015, 1-13; Melinda J Milligan, 'Buildings as History: The Place of Collective Memory in the Study of Historic Preservation', Symbolic Interaction 30, no. 1 (2007): 105-23.

${ }^{8}$ Gill Chitty, ed., Heritage, Conservation and Communities: Engagement, Participation and Capacity Building (Abingdon, Oxon: Routledge, 2017); Elizabeth Crooke, 'The Politics of Community Heritage: Motivations, Authority and Control', in Heritage and Community Engagement: Collaboration or Contestation?, ed. Emma Waterton and Steve Watson (Abingdon: Routledge, 2013); Bryony Onciul, Michelle L. Stefano, and Stephanie Hawke, eds., Engaging Heritage, Engaging Communities (Woodbridge, Suffolk: Boydell Press, 2017).

${ }^{9}$ Crooke, 'The Politics of Community Heritage', 27.

${ }^{10}$ Crooke, 27.
} 
usually identified before their communities or values are considered. ${ }^{11}$ There are some isolated examples of alternative practices, which used communities and thematic histories as a starting point to then identify and research places. ${ }^{12}$

Different ways to consider communities of place can be developed through notions of practice, interest and use. Andrea Witcomb acknowledged Tony Bennett's argument that community is a construct of research and engagement techniques, but also argued this failed to recognise the agency of those groups. This led her to conceptualise heritage professionals as their own communities of practice. ${ }^{13}$ Lisanne Gibson built on this to propose a dialogical relationship between communities of practice and non-practice. ${ }^{14}$ If Witcomb's notion of 'communities of practice' opens the possibility of dialogical communication between communities of place and practice, this can be expanded to multi-dialogical model between multiple communities of place and practice. Many different professions that have a bearing on built heritage; 'communities of practice' allows these to be separated into 'communities of profession.' The term 'communities of interest' can be used to encompass practice and nonpractice groups that might all have a subtle interest - a vested interest or curiosity - in a place. $^{15}$

Notions of 'use' are another way to understand the communities associated with a place. People use and interact with places in a variety of ways, from active to latent, physical to meta-physical. Uses imbue places with meaning, and thus places may have a number of 'communities of use.' If 'profession' can be used to understand communities of practice, then 'use might be used to understand communities of non-practice. However, professions also use heritage in some senses, such as to recognise the evolution of their professions, celebrate

\footnotetext{
${ }^{11}$ Lisanne Gibson, 'Cultural Landscapes and Identity', in Valuing Historic Environments, ed. Lisanne Gibson and John Pendlebury (New York: Routledge, 2009); Nigel Walter, 'From Values to Narrative: A New Foundation for the Conservation of Historic Buildings', International Journal of Heritage Studies 20, no. 6 (2014): 634-50, https://doi.org/10.1080/13527258.2013.828649.

${ }^{12}$ Celmara Pocock, David Collett, and Linda Baulch, 'Assessing Stories before Sites: Identifying the Tangible from the Intangible', International Journal of Heritage Studies 21, no. 10 (2015): 962-82, https://doi.org/10.1080/13527258.2015.1040440; Siân Jones, 'Wrestling with the Social Value of Heritage: Problems, Dilemmas and Opportunities', Journal of Community Archaeology \& Heritage 4, no. 1 (2017): 1-17, https://doi.org/10.1080/20518196.2016.1193996. Heritage New Zealand's (then Historic Places Trust) Rangitikei-Ruapehu community-engagement pilot project (2003-2005) was another, but this has not been published

${ }^{13}$ Re-Imagining the Museum: Beyond the Mausoleum, Museum Meanings (London; New York: Routledge, 2003), http://ebookcentral.proquest.com/lib/vuw/detail.action?docID=170673.

14 'Cultural Landscapes and Identity', 88.

15 'Communities of interest' has many similarities with terms like 'affected parties' and 'stakeholder communities' used in planning. However, this research does not engage with planning literature - 'communities of interest' is used to divorce it from this context. It allows for the subtleties of heritage 'interests' in places.
} 
prominent practitioners, and continue their practice. Therefore, in this case 'use' might be understood as a type of interest in the place. Either way, use and interest are two concepts with which to connect communities of place with pre-existing communities.

\subsection{Participatory practice}

Participation processes involve communities from outside institutions in decisions and practices which affect them. 'Participation' has been widely lauded and used over the last half-century, particularly in areas of governance and development. In these contexts, 'The overall purpose of citizen participation is to enhance the quality and legitimacy of policy decisions, thus overcoming the problems faced by representative democracy, especially when dealing with wicked problems, multi-faceted issues, and fragmented policy environments.' 16 Fundamentally, there are many gradations of citizen participation, as articulated by Sherry Arnstein. ${ }^{17}$ This graduation has been formalised in the widely-used IAP2 Public Participation Spectrum. IAP provides that 'differing levels of participation are legitimate depending on the ... decision to be made ... [and] ... sets out the promise being made to the public at each participation level.' 18

Low levels of public engagement allow a community no control in the decision. This includes informing, which disperses information, and consulting, which allows input without reaching out to those affected. At higher levels of participation, such as involvement and collaboration, the public has increasing input in the process and a greater level of power in the eventual decision. At the highest level of public participation, the public is empowered in decisionmaking. The distribution of power is a critical consideration.

However, there are more nuances to participation than the spectrum of input and control. ${ }^{19}$ The motivations for participation (both the institution's and the community's) impact the process. All forms of participation place a burden on participants. Dynamics within communities interact with participation processes, so the wellbeing of the community needs to be a consideration. Finally, the capacity of the communities also need to be considered - as

\footnotetext{
${ }^{16}$ Mario Ianniello et al., 'Obstacles and Solutions on the Ladder of Citizen Participation: A Systematic Review', Public Management Review, 2018, 1, https://doi.org/10.1080/14719037.2018.1438499.

17 'A Ladder of Citizen Participation', Journal of the American Planning Association 35, no. 4 (1969): 216-24, https://doi.org/10.1080/01944366908977225.

${ }^{18}$ International Association for Public Participation Australasia, 'Spectrum', accessed 18 May 2018, https://www.iap2.org.au/About-Us/About-IAP2-Australasia-/Spectrum.

19 Andrea Cornwall, 'Preface', in The Participation Reader, ed. Andrea Cornwall (London: Zed Books, 2011), xii-xx; Ianniello et al., 'Obstacles and Solutions on the Ladder of Citizen Participation: A Systematic Review'.
} 
Gibson ${ }^{20}$ argued, 'enabling the agency of people and communities is only possible within frameworks of action and by utilizing particular techniques and capacities which are not innate.'

Participation can have a number of different roles in decision-making processes. Processes can be used to gather information, including subjective information such as opinions. They can also be used to develop a mandate for the decision. This also exists along a spectrum: very superficial engagement can be used to tout decisions that were not formed by the community and against their best interests. ${ }^{21}$ At a higher end of the spectrum, participation can be used to actively develop community consent. Collective action can also be a form of participation, which moves the notion of participation beyond notion of 'invited' or intentionally participatory processes. ${ }^{22}$ In heritage, participation can have particular impacts because the participation is itself a type of heritage practice. Heritage-making participation processes include creation and articulation of knowledge and negotiation of meaning.

\subsection{Formal heritage structures: values and assessments}

In institutions, such heritage-making processes of knowledge (re)production and meaning negotiation often happen through notions and frameworks of value, which are facilitated by value assessment processes.

Notions of value and significance underpin heritage theory and practice. Heritage theory and the practice sector are founded on the idea that there is something important or special about heritage - that it has value and significance. ${ }^{23}$ The question is why or what about certain heritage is valuable and significant. As Kate Clark points out, values are not absolute: values are cultural perspective, and can be contested and conflicting. ${ }^{24}$ The question then becomes 'what values?' - or rather 'whose values?'

Values frameworks formalise modes of valuing into constructed categories. The meanings, associations - the importance - of a place are then formally understood and managed through these frameworks. Organisations develop their own frameworks according to their mandate,

20 'Cultural Landscapes and Identity', 88.

${ }^{21}$ Arnstein, 'A Ladder of Citizen Participation'.

${ }^{22}$ Cornwall, 'Preface', xix.

${ }^{23}$ Kate Clark, 'Values in Cultural Resource Management', in Heritage Values in Contemporary Society, ed. George S Smith, Phyllis Mauch Messenger, and Hilary A Soderland (Walnut Creek, Calif.: Left Coast Press, 2010), 91.

${ }^{24}$ Clark, 92 
priorities, and perspective (although influenced by wider trends). There are always different ways to regard the same set of values, and there is generally overlap in categories.

Heritage assessment codes information and meaning into heritage values frameworks. Assessment processes gather information, assign meaning to this information, and determine how heritage places are regarded within heritage formal systems. They formulate the nature and degree of the value or significance of a place. ${ }^{25}$

This dissertation takes the position that values are not objectively assessed but subjectively assigned. Two fundamental impacts of assessments are that they freeze a place's value, belaying that value is fluid; and that, because of the power structures of knowledge, assessments become gospel - the values articulated are regarded as the values, rather than $a$ (subjective, possibly biased) articulation of certain associated values. Assessment methodologies have an inherent role in shaping the value of data, including whose voices are included and how the methodology frames the nature of the value category.

\subsection{Social value}

This discussion of alternative heritage practices, non-institutional views of heritage held by communities, and formal values frameworks brings us to social value.

Social value is a notion encompassing the uses, associations, connections, and meanings of a place to contemporary people. Historically, social value was a category used to capture the 'non-expert' values of a place, just as community has been defined as 'non-expert. ${ }^{26}$ Social value is not just about personal associations, but collective associations and meanings; it recognises the qualities by which heritage forms a group. ${ }^{27}$ This sees places as physical resources in creating social connections through time. By nature, social value is fluid, dynamic and contested. ${ }^{28}$ 'Sense of place' is often used in similar ways but is a more personal and informal concept, commonly used to 'describe the emotional attachment people have to the places they hold dear.' 29 'Social value' as a category recognises the attachments that

\footnotetext{
${ }^{25}$ Chris Johnston, 'What Is Social Value?' (Canberra: Australian Heritage Commission, 1992), 3.

${ }^{26}$ Jones, 'Wrestling with the Social Value of Heritage: Problems, Dilemmas and Opportunities'; Johnston, 'What Is Social Value?'; Elizabeth Pishief, 'Engaging with Māori and Archaeologists: Heritage Theory and Practice in Āotearoa New Zealand', in Engaging Heritage, Engaging Communities, ed. Bryony Onciul, Michelle L. Stefano, and Stephanie Hawke (Woodbridge, Suffolk: Boydell Press, 2017), 55.

${ }^{27}$ Johnston, 'What Is Social Value?'; Chris Johnston, 'Inhabiting Place: Social Significance in Practice in Australia', APT Bulletin 45, no. 2/3 (2014): 39-47.

${ }^{28}$ Jones, 'Wrestling with the Social Value of Heritage: Problems, Dilemmas and Opportunities'.

${ }^{29}$ John Schofield and Rosy Szymanski, 'Sense of Place in a Changing World', in Local Heritage, Global Context : Cultural Perspectives on Sense of Place, ed. John Schofield and Rosy Szymanski (Farnham, Surrey: Ashgate, 2011).
} 
communities form with places and the meanings that places embody. This makes it one way of integrating community views into heritage management.

The literature suggests that social value currently holds a tenuous position in formal heritage management. Social value as a category appears in various heritage frameworks in various ways. Definitions and terminology are not universal. Community value, cultural value, and communal value are all other terms in formal frameworks, often with slightly differing definitions. Some high-level and influential policy documents place social value (or similar concepts) on-par with other heritage values. These include the Burra Charter, English Heritage's Conservation Principles, and the Faro Convention. ${ }^{30}$

However, scholars argue that social value is currently marginalised in formal heritage management by practice and policy. Waterton, Smith and Campbell (in ${ }^{31}$ and Smith 2006) argue that although the likes of English Heritage, the Burra Charter and the Faro Convention theoretically declare social value to be equal to other value categories, the processes that underpin these still privilege expert value categories and physical fabric. Social value is often conflated with more traditional value categories, especially historical and architectural values, and social value recognition more likely to happen on a limited or one-off basis rather than being routine. ${ }^{32}$ Furthermore, the processes that assess and articulate social value in formal heritage management undermine policy statements.

Scholars such as Siân Jones and Chris Johnston argue that the single biggest challenge for social value is the lack of regular, rigorous, feasible methods for seeking social value directly from the community -of-place. Historically, value has been assessed by experts making 'objective' assessments on the basis of their knowledge. However, social value is explicitly held by the community of a place, and scholars argue that assessment needs to engage with them. These methods and approaches to social value are a form of community participation in heritage, and thus can be considered through a participatory framework.

\footnotetext{
${ }^{30}$ ICOMOS Australia, 'The Australia ICOMOS Charter for Places of Cultural Significance' (2013), http://australia.icomos.org/wp-content/uploads/The-Burra-Charter-2013-Adopted-31.10.2013.pdf; English Heritage, 'Conservation Principles, Policies and Guidance', 2008; Council of Europe, 'Council of Europe Framework Convention on the Value of Cultural Heritage for Society' (2005), https://rm.coe.int/1680083746. ${ }^{31}$ Gibson, 'Cultural Landscapes and Identity'.

${ }^{32}$ Jones, 'Wrestling with the Social Value of Heritage: Problems, Dilemmas and Opportunities', 33.
} 


\subsection{Considering social value as participation}

A broad array of work is being done around formal ways to engage with social value. This is occurring in a range of contexts, including formal heritage organisations, academia, commercial enterprises, and various partnerships therein. I argue that this work sits along a spectrum of participation, with different approaches to 'community' and different priorities and intentions. This literature review is only able to discuss a few select case studies to illustrate this point.

Some scholars prioritise developing and implementing assessment procedures that integrate social value into institutional frameworks. These need to meet formal management requirements for consistent and rigorous methodology assessment while flexibly, broadly and qualitatively assessing social value. ${ }^{33}$ Jones argues that large-scale surveys and consultation processes are inadequate for understanding a specific place's social value. ${ }^{34}$ Rapid ethnographic assessment procedure (REAP) and similar techniques can be used to develop nuanced understandings of the community's sense of place within formal heritage frameworks. These involve deploying multiple social research techniques (such as focus groups, in-depth and walking interviews, and observations) in an iterative manner and in a short time to develop and validate findings. These approaches are more feasible than more intensive social research approaches such as oral histories, as they can be conducted in a relatively short time frame with a relatively small team. Nevertheless, they are skill- and resource-intensive.

Johnston specialises in these methodologies and often uses REAP, such as in assessing the social and aesthetic qualities of Broken Hill City (NSW, Australia), and the social heritage values of the Wedge and Grey shack settlements in Western Australia. These projects revealed the nuances of connection and meaning, and contributed to the official heritage listing of the settlements. ${ }^{35}$ Many other examples, particularly out of academia, also focus on qualitative understandings of social value without involving the public in heritage decisions. ${ }^{36}$

\footnotetext{
33 Johnston, 'Inhabiting Place'.

${ }^{34}$ Jones, 'Wrestling with the Social Value of Heritage: Problems, Dilemmas and Opportunities', 26.

35 Johnston, 'Inhabiting Place'.

${ }^{36}$ Stephen Townend and Ken Whittaker, 'Being Accounted For: Qualitative Data Analysis in Assessing 'Place' and 'Value', in Local Heritage, Global Context: Cultural Perspectives on Sense of Place, ed. John Schofield and Rosy Szymanski (Farnham, Surrey: Ashgate, 2011), 65-78; Hilary Orange, 'Exploring Sense of Place: An Ethnography of the Cornish Mining World Heritage Site', in Local Heritage, Global Context: Cultural Perspectives on Sense of Place, ed. John Schofield and Rosy Szymanski (Farnham, Surrey: Ashgate, 2011), 99118; Rodney Harrison, 'CCounter-Mapping' Heritage, Communities and Places in Australia and the UK', in
} 
These methods give the community a voice and collect nuanced points of view/value, but are still mediated by a professional within a formal system of research and decision-making.

Some researchers go beyond assessing social value to collaborative and co-produced heritage making. Social value can be explicit or implicit in these projects. They often include ethnographic techniques, but also use engagement methodologies empower communities and negotiate value. Jones adopted a co-production approach for the ACCORD project, working with several communities across Scotland and in partnership with a number of heritage organisations. ${ }^{37}$ The community was actively engaged in the heritage-making process (including place identification and digital recording, facilitated with experts). The project explicitly considered how these technical heritage practices were active processes of value negotiation through a social value perspective. ${ }^{38}$

Svava Riesto and Anne Tietjen studied two participatory heritage planning projects in Denmark. Ethnographic methods were used alongside participatory design methods. The projects were facilitated by a number of professionals including planners and museum professionals (acting as local heritage advisors) and negotiated transformation of physical fabric and marketing brands for places. These projects created more nuanced considerations of social value than formal heritage institutions would have recognised. Social value was an implicit part of these projects, as the goal was to undertake collaborative heritage planning in a way that reflected wider democracy in society. ${ }^{39}$

As another example, the British NGO Common Ground facilitates communities to articulate their own 'sense of place' to enhance individual and community wellbeing, rather than for the formal record or management. ${ }^{40}$

These examples show that participatory engagement/research can reinforce social value and community. It can build capacity within the community both for engaging with heritage and with wider participatory and democratic processes. As Kim Dovey put it: ${ }^{41}$

Local Heritage, Global Context: Cultural Perspectives on Sense of Place, ed. John Schofield and Rosy Szymanski (Farnham, Surrey: Ashgate, 2011), 65-78.

37 Jones, 'Wrestling with the Social Value of Heritage: Problems, Dilemmas and Opportunities'.

${ }^{38}$ Jones, 28.

39 'Doing Heritage Together - New Heritage Frontiers in Collaborative Planning', in Heritage, Democracy and the Public: Nordic Approaches, ed. Torgrim Sneve Guttormsen and Grete Swensen (Oxon: Routledge, 2016), $159-74$.

${ }^{40}$ Sue Clifford, 'Local Distinctiveness: Everyday Places and How to Find Them', in Local Heritage, Global Context: Cultural Perspectives on Sense of Place, ed. John Schofield and Rosy Szymanski (Farnham, Surrey: Ashgate, 2011), 1-12.

${ }^{41}$ Gibson, 'Cultural Landscapes and Identity', 88-89. 
Educating communities to research and defend their places of value is easier to justify than the determination that such places are to be protected by law against development. Such an approach avoids some of the dilemmas ... in that it does not measure, define, judge, or paralyse places of social value. Rather it empowers and enables people to define themselves and places as part of the general development of democratic social life.

One consideration for participation in heritage governance is how meaning is mediated though the researcher's frameworks. All dialogical processes are embedded with knowledge/power relations. Lisanne Gibson (2009) uses Pierre Bourdieu to argue that public opinion is always framed and modulated by research techniques, and Tony Bennett to discuss that social research actually produces public opinion. Another issue is that communities can be constructed through institutional attempts to engage with them. ${ }^{42}$ These communities may not be self-identifying, let alone self-organised.

Despite considering these examples along a spectrum, it is worth considering how they all frame 'place' and 'community'. These examples all use qualitative approaches to flexibly explore the meanings and associations of a place. They frame the place in question typically as a wider area such as a suburb, town, or region, rather than a single building. This indicates that it might not be appropriate to isolate the 'social value' of a single building. They also frame the community as geographically attached to the place, geographically distinct, without considering community transience. This is problematic for social value in urban environments, where communities might be harder to define spatially, mingle between areas more, and be highly transient.

Social value is also assessed in non-participatory ways. This is particularly enabled if the concept is not exclusively applied to the contemporary community (as I use it), and therefore applies to 'social history' as much as the present day. Evidence used can include historic events like anti-demolition campaigns, open-for-letters consultations, books, and artworks. I identify two issues here: one, these forms of evidence privilege a certain class of people for whom engaged, civic leisure activity is a norm. Two, these sources can be part of the authorised discourses of heritage, in that they evidence and produce meaning and social value. Social value is also sometimes assessed from city planning or use theory. For example, prominent or often used public building may be assessed as having a high social value. I would argue that these approaches can estimate whether a place has social value, but cannot establish the specific underlying meanings and associations. They also do not realise the

\footnotetext{
${ }^{42}$ Crooke, 'The Politics of Community Heritage'.
} 
potential of social value as a democratising influence in heritage management. Furthermore, this approach may seriously fail if the social value falls outside the cultural understanding of the heritage system, such as for indigenous places.

\subsection{Towards the research}

This literature review has introduced this dissertation's definition of heritage and outlined some key ideas of heritage dissonance, community, participation, values and assessments. It has then brought these ideas together under the notion of community-held social value, and introduced some examples of participatory approaches to social value.

The literature on social value in intuitional processes leaves scope for further investigation, particularly in terms of participatory practice. A number of issues seem to be unstudied, including the use of such processes in New Zealand, impact of social value and participation processes on decision-making, and their role in local urban heritage management. Particularly, the social value literature does not consider collective action as a form of participation that can be used to consider social value. There a number of reasons for this, given that much of the literature seems to focus on processes that fit the needs of 'neutral' heritage management. However, there is scope to consider the relationship between participation practices that a community is undertaking of its own accord, using existing platforms for representation, and considering their relationship with social values and general heritage values.

Therefore, key research questions going forwards are:

1) What heritage values can be expressed through collective action?

i. Particularly, what social values can be expressed?

2) What is the relationship of those values to the participation processes, communities, and wider situation that produced them?

3) What is the impact of the expressed values on institutional rhetoric and decisions? 


\section{Research Design}

This chapter sets out the research design used to investigate the research questions (stated above). I adopted a case-study approach. The selection of a case is discussed, mentioning some of the options which were not selected, and introducing the Christchurch Town Hall advocacy case-study. The use of heritage advocacy campaigns as case-studies is briefly discussed. The method of data collection is then laid out, as are the sources used. The method for analysing the data follows, and the chapter concludes with a discussion the limitations of this research.

\subsection{Research Strategy}

This research took a case study approach. Case studies are almost ubiquitous in heritage research of this scale. They allow for a deep and contextual analysis of a relatively discrete, self-contained, and ideally completed case. Case studies have the advantage of allowing an in-depth study of a single or few key instances of something, with a focus on relationships and processes involved. They also allow for a holistic, contextualised view and the use of multiple methods. It also allows a 'naturally occurring' situation to be studied. ${ }^{43}$ All of these characteristics were considered critical to examine the role of participation social value in a context of New Zealand heritage.

Disadvantages of case studies are that they sacrifice breadth and transferability. Studying one case in New Zealand heritage management gives no indication of how other cases might pan out, even if quite similar. Findings are highly contextual and unlikely to be transferable to other situations. This issue was intensified by the selection of a case-study in post-quake Christchurch. This was a highly unusual situation in many ways. It is highly unlikely to be relevant to any other New Zealand context, or even post-disaster context.

The search for an appropriate case-study was a difficult part of this research process. There appear to be few published examples of New Zealand participatory heritage research (at least using that terminology). Networks were essential in gaining an idea of current practice and potential case studies. The eventual choice of case study of the Christchurch Town Hall after the earthquakes was highly motivated by personal connections.

\footnotetext{
${ }^{43}$ Martyn Denscombe, The Good Research Guide: For Small-Scale Social Research Projects, Fifth edition. (Maidenhead, UK: Open University Press, 2014), 54-56.
} 
Other case studies considered included Heritage New Zealand's (HNZPT) RangitikeiRuapehu community-engagement pilot project (2003-2005). ${ }^{44}$ This used participatory techniques to inform the listing of new places on the HNZPT List, using a range of ethnographic techniques. Social value did not appear to have been a focus of the project, nor does it appear to have become HNZPT practice. Due to the age of the project, people involved in the project may not have been available to interview, it was unlikely to have a direct relationship with current practice.

Another potential case-study was Omaio ki Tua, an ongoing marae-based community archaeology project in Hawkes Bay. ${ }^{45}$ This also did not appear to have made social value an explicit focus. This dissertation was also intended to focus on built heritage rather than archaeology. It also would have required engaging with Māori and other academics in an ongoing process. I did not have the appropriate skills to undertake research with Māori nor the developed relationships that might have enabled this to be a case-study.

Christchurch City Council's (CCC's) 2017 'Future of Heritage' survey was another possibility. This survey explicitly used social research and participation techniques to investigate residents' attitudes to heritage. It is also an ongoing project, as the subsequent Christchurch City Council Heritage Strategy is still being written. ${ }^{46}$ As an official process, it may have been hard to access necessary sources and may have been sensitive research.

The case study of the Christchurch Town Hall after the Canterbury earthquakes developed through two factors. I had personal connections to Christchurch and had briefly explored potential participatory/heritage intersections in post-quake Christchurch. The Town Hall was suggested by Anne Cunningham, a participatory development professional, working in cultural activism, architecture and urbanism. Post-quake Christchurch offered a case-study rich with emotions, meaning, and associations, as the widespread destruction of the built environment had thrown the social significance of the built environment into sharp relief The Canterbury Earthquakes 2010-2011 started with a 7.1 magnitude quake on 4 September 2010 which resulted in substantial building and infrastructure damage but no loss of life; a subsequent 6.2 magnitude quake on 22 February 2011 resulted in significant building and infrastructure damage and 185 deaths. There were numerous influential heritage campaigns

\footnotetext{
${ }^{44}$ Then Historic Places Trust New Zealand.

${ }^{45}$ Naomi Arnold, 'On the Edge', Heritage New Zealand Magazine, no. 148 (Autumn 2018): 36-41.

${ }^{46}$ Christchurch City Council, 'The Future of Heritage', Chrsitchurch City Council Website, accessed 4 June 2018, https://ccc.govt.nz/the-council/consultations-and-submissions/haveyoursay/show/15.
} 
and debates. The destruction of the quakes sparked nation-wide anxiety about the seismic safety of buildings, particularly of unreinforced masonry (URM) buildings. Legislation was introduced that requires earthquake strengthening in some situations; this has become an urgent focus for heritage nation-wide since the Canterbury earthquakes. ${ }^{47}$

The Town Hall sustained earthquake damage and demolition was suggested as a possibility in 2012. An advocacy campaign occurred over three years (2012-2015), including three separate votes by the owner, CCC to restore it in full. This campaign had advantages as a case study. It was well-defined, as it clearly commenced because of the quakes and ended with the final decision to rebuild. It was less contentious than arguments over the Christchurch Cathedral, which were long-running and vicious, including multiple negotiating organisations. The Town Hall is a secular building, which removed a layer of complexity. As a building owned by the Christchurch City Council, key documents relating to it were publicly available either already online or through Local Government Official Information Act (LGOIA) requests.

A particular appeal of the Town Hall was that key individuals in it were also involved with other grassroots projects in post-quake Christchurch - specifically in the Festival of Transitional Architecture (FESTA), the Christchurch Centre for Architecture and CityMaking (Te Pūtahi), and the heritage advocacy collective Interests in Conserving the Identity of Christchurch (IConIC). These individuals were Dr. Jessica Halliday, Barnaby Bennett, and Prof. Ian Lochhead. These connections raised the possibility that the Town Hall advocacy could represent an intersection between multiple modes of practices, including grassroots participatory practice. This research was largely geared towards investigating these connections. I focused on the advocacy and practice of the Keep Our Town Hall (KOTH) group in order to focus on these pre-identified relations, and also to focus on their practice as self-identified heritage actors.

Anne Cunningham acted as an advisor to this research and was the point of contact to the key informants through her professional connections. She was co-director and project director of Te Pūtahi and worked closely with Halliday.

\footnotetext{
${ }^{47}$ Eric Crampton and Linda Meade, 'Deadly Heritage' (Wellington, NZ: The New Zealand Initiative; Deloitte New Zealand, May 2016), https://nzinitiative.org.nz/reports-and-media/reports/deadly-heritage/; Imogen Stockwell, 'Making a House a Home: Motivations for Earthquake Strengthening Domestic Homes in Dunedin, an Argument Towards Domestic Heritage' (Victoria University of Wellington, 2016).
} 


\subsection{Heritage campaigns as case studies: strengths and limitations}

Heritage campaigns, in my definition, are instances where a community (or communities) respond to a threat to a specific heritage. ${ }^{48}$ Studies on heritage advocacy campaigns are commonplace in heritage theory. ${ }^{49}$ They are histories in their own right, allowing for examination of the historic development of conservation/preservation as a social movement and other historic trends. They can also provide case studies of heritage practices. They can be convenient case-studies with easily-definable location and duration. They often produce clear communities, as they are required to organize in order to create the campaign. ${ }^{50}$

Heritage campaigns can be particularly good arenas for analysing heritage values and discourses. They often elicit (indeed, may be based on) strong emotions, articulate multiple meanings, and become a forum for the collection of viewpoints. The advocacy arguments are likely to represent the points that the advocates believe will be most effective, even if those are not the points that motivate the advocates. Heritage campaigns can also illuminate differences between grassroots communities of heritage actors, and institutional heritage practices.

While heritage campaigns can serve as useful case-studies, they also have limitations. Heritage campaigns are usually studied retroactively, and it could be said that they teach us little about how we can change future practice. They are non-normative instances of heritage action and performance. They are usually distinct occasions (even if they fit into broader movements) and they often operate outside normal heritage institutions.

They can also be a distorted perspective on the value of heritage to communities of interest, as the community assembled and the value was articulated in the context of a threat. Rodney Harrison discusses how all heritage is defined, at least in part, against the threat of loss. ${ }^{51}$ Heritage campaigns articulate heritage value (including social value) in a context of hyperthreat. Therefore, heritage campaigns can have significant impacts on the values, meanings,

\footnotetext{
${ }^{48}$ I avoid the term 'heritage battle' because of its highly emotive connotations.

${ }^{49}$ in the USA: Max Page and Randall Mason, eds., Giving Preservation a History: Histories of Historic Preservation in the United States (New York: Routledge, 2004); in New Zealand: Elizabeth Cox, A Friend Indeed: The Saving of Old St Paul's (Wellington, NZ: The Friends of Old St Pauls, 2018); Alex Gordon, 'Another Old Lady to Be Knocked Down: Heritage Discourse and the Protest to Save the Missions to Seamen Building, 1986' (Victoria University of Wellington, 2018); in Australia: Louise Blake, 'Rescuing the Regent Theatre', Provenance: The Journal of Public Record Office Victoria, no. 11 (2012), https://www.prov.vic.gov.au/index.php/explore-collection/provenance-journal/provenance-2005/rescuingregent-theatre.

${ }^{50}$ Crooke, 'The Politics of Community Heritage', 27; Gill Chitty, 'Introduction: Engaging Conservation Practising Heritage Conservation in Communities', in Heritage, Conservation and Communities: Engagement, Participation and Capacity Building, ed. Gill Chitty (Abingdon, Oxon: Routledge, 2017), 4.

${ }^{51}$ Heritage: Critical Approaches.
} 
and (memory) uses of heritage places. However, it is difficult to qualify exactly what that affect is (especially as it is unlikely that a control study would have been done prior to a heritage campaign).

Heritage campaigns also tend to be motivated and organised by a few key players. This can distort the perception of public opinion and make it difficult to assess the value to the wider (potential) community. Heritage campaigns can become part of the legacy of the heritage place, further distorting its significant at or before the time of the threat.

The outcomes of heritage campaigns can illustrate that heritage decisions are never made within tidy frameworks of heritage values, and there are usually far greater political, economic, and societal forces in play. Heritage issues are physical and metaphysical sites for the negotiation and competition of wider issues, and 'heritage' campaigns are arenas for this.

\subsection{Research methods and sources}

In order to respond to the research questions, sub-question for the case-study were:

- To what extent was the Town Hall advocacy a participatory practice?

- To what extent were post-quake participatory practices heritage practices?

- How did heritage advocacy and democracy interact in post-quake Christchurch?

Investigating the main research questions relating to expressions of value, the context the processes, and the impact of them, required large and varied array of data from a variety. Like much documentary research, this method used a snowball approach where each source led to other events and sources. The goals of the data collection were to:

- understand the progression of the Christchurch Town Hall advocacy,

- analyse the value judgements made about the Town Hall,

- analyse the council decision(s) in context of broader political considerations,

- understand the advocates' goals, motivations, and strategies, and,

- consider related urban activism practices, particularly whether they could be considered heritage practices.

The sources I utilised are discussed below. 


\subsubsection{Documentary sources}

An overview of politics and planning of post-quake Christchurch was developed through analysing documentary sources, including articles, blogs and books. Many of these were written by the key informants (see below). These represented subjective viewpoints and allowed the Town Hall advocacy to be contextualised within the informants' perspectives. Sources included presentation and public discussion made by these individuals at previously, such as the TEDx Christchurch event in 2014, a mini-conference on 'The Transitional City' hosted by the New Zealand Centre for Sustainable Cities in 2014, and the 'Heritage, Activism, Architecture' event hosted by Parlour for Melbourne Design Week in 2018.

Documentary sources on post-quake urban activism were short news articles or articles written by the key activists. Again, this allowed the analysis to focus on activists' viewpoints. Online news articles were also used to identify and verify key events, and to consider how these were presented to the general public.

\subsubsection{Official CCC and CERA documents}

Official CCC and CERA documents such as meeting minutes, agenda, reports, internal communication, and annual and long-term plans were used to understand the progression of events and their implications, and to consider the official value judgements made regarding the Christchurch Town Hall.

\subsubsection{Submissions to CCC Plans}

A LGOIA request was made to CCC for all submissions it received regarding the Christchurch Town Hall from 2011-2015. This included the submissions made regarding the Annual Plan 2012/13, the Three-Year Plan 2013-16, the Annual Plan 2014-15, and the LongTerm Plan 2015-25. This relied on CCC identifying all the Town Hall related submissions.

These submissions were made to CCC under its usual consultation processes, when the Town Hall was just one among many issues at hand. As such, these submissions serve to illustrate two issues. One is the type of value/meaning statements that might be made under normative, non-focused consultation. The other is the value judgements made concerning the Town Hall by a sample that was not necessarily actively advocating for it. 


\subsubsection{Keep Our Town Hall support letters}

One of the key KOTH strategies was to solicit letters of support. KOTH presented these letters to Council and included them in their submissions. These letters were a source to analyse the value judgements made by supporters about the Town Hall. They also illustrated KOTH's strategy and allowed the strategy to be linked to the type of value judgements made. The KOTH support letters were provided by CCC under the LGOIA.

\subsubsection{Deputations to Council}

KOTH and other groups made deputations a total of five times - twice to the Culture, Recreation and Arts Committee (CRAC) and three times to Council. These deputations were the chief source in which the KOTH advocates expressed their value judgements of the Town Hall. The deputations of other groups, including Voice of Music and the Friends of the Christchurch Town Hall Organ, were also analysed for their value judgements. These were also the main source from which the history of the Town Hall was established.

Pre-written deputations for 2012 and 2013 were provided by CCC under the LGOIA. The 2015 deputations were analysed through CCC's online archive of live-streamed Council meetings (CCC started live-streaming council meetings in late 2013). This allowed for a more detailed analysis of the 2015 deputations, including vocal cues and councillors' responses through questions.

\subsubsection{Council debates}

The 2015 debate leading to the final council decision was analysed through the archived meeting video. This allowed for a detailed analysis for the values judgements and rhetoric made by the councillors during the debate, and to consider the factors in the final decision. It also allowed for the consideration of the final Town Hall business case as presented to Council.

The 2012 and 2013 decisions were briefly considered, based on the limited council minutes, brief quotes in news reports and comments from interviews. However, this did not provide enough information for a detailed analysis.

\subsubsection{Key informant interviews}

Interviews were undertaken with three of the key KOTH advocates - Jessica Halliday, Barnaby Bennett and Ian Lochhead. These individuals were selected because of connections 
though the research advisor, and because they were involved in other projects including heritage advocacy and urban activism.

Halliday is an architectural historian who grew up in Christchurch. She has an art history $\mathrm{PhD}$ in architectural history. Her heritage activities include consulting on conservation plans (including the Christchurch Town Hall), serving on the board of DOCOMOMO and advocating for Christchurch as an early member of IConIC. She is the director of FESTA and of Te Pūtahi. She writes and speaks widely on architecture, urbanism, and activism in postquake Christchurch.

Bennett is an unregistered architect and a designer. A week before the February 2011 earthquake he started a $\mathrm{PhD}$ in architecture at the University of Technology, Sydney (UTS) on the emergence of temporary and transitional architecture in post-quake Christchurch. $\mathrm{He}$ subsequently moved to Christchurch at the beginning of 2012 and became involved with a number of the urban activism, participatory, and temporary projects. He was a board member for governing organisation of FESTA and Te Pūtahi. He left Christchurch at the end of 2015. $\mathrm{He}$ is a co-founder of Freerange Press, a small cooperative publishing company focusing on issues relating to post-quake Christchurch, design, politics and art. He was a co-editor of Christchurch: The Transitional City Part IV (2012) and of Once in a Lifetime: City-building after Disaster in Christchurch (2014). He writes widely, particularly on the blogs Project Freerange and Making Christchurch.

Lochhead is an associate professor of art history at the University of Canterbury. He has written extensively on art history and architectural history. His speciality is the history of New Zealand and Christchurch architecture. He is a prominent member of IConIC and Historic Places Canterbury.

Interviews were conducted in late April and early May 2018. Halliday and Lochhead were interviewed in cafes in Christchurch and Bennett was interviewed by Skype from Australia. A timeline of events, established from documentary sources, was used as a memory aid in interviews.

Interviews were focused on uncovering the interviewees' motivations, strategies and perspectives on the advocacy. Interviews were not used to produce value judgements on the Town Hall as these had been well-stated in the deputations and other articles. 
The interviews had an unstructured format. Interviews were approached with a few key topics to cover, but were largely conversational and developed iteratively - ideas or points from one were taken to subsequent interviews. Evolving analysis and framing of the case-study greatly influenced interview questions and format. Each of the three interviewees had different positions regarding the Town Hall advocacy and other grassroots projects, so an identical interview template was inappropriate.

Ethics approval was granted by the Victoria University of Wellington Human Ethics Committee (application 25792). Interviewees were informed about the parameters of the project and retained rights of editing over their interviews. It was not possible to anonymise the interviewees as the topic was specific and participants would have been highly identifiable.

\section{4 $\quad$ Analysis method}

As with all qualitative research, the data analysis for this research was 'a messy, ambiguous, time-consuming, creative and fascinating process. ${ }^{, 52}$ Different methods were used with different sources to address the research questions. Each of these had limitations, and the analysis should be considered in light of these.

A ground theory approach was used for the analysis of the advocacy representations to CCC (general submissions, support letters, and deputations). This analysis relied on a strong grounding in the context which produced the representations. ${ }^{53}$ This is one reason why a detailed analysis of the context of post-quake Christchurch was integral to this research. The representations were re-read (or listened to) several times.

The representations were analysed for 'units of meaning' which were read as 'value statements' which expressed the values of the Town Hall. A value framework was applied, following the literature and the research questions. This 'value framework' was not predefined in a formal framework. Rather, the meanings of the values statements were flexibly analysed, while broadly using a structure of architecture, history and other values. The analysis paid close attention to the content of representations, particularly support letters. This close-reading of content could risk missing implied meanings. ${ }^{54}$ However, part of the analysis intention was to consider the impact of analysis. Additionally, intended and

\footnotetext{
${ }^{52}$ Denscombe, The Good Research Guide: For Small-Scale Social Research Projects, 294.

${ }^{53}$ Denscombe, 285-88.

${ }^{54}$ Denscombe, 284.
} 
expressed meanings were likely to align, as these letters were crafted to clearly communicate their point to the intended audience (the Council).

This analysis was done manually. This was the most expedient method give the volume of data, the depth of analysis required, and the time constraints. The use of software such as NVivo may have aided deeper analysis, particularly regarding the connections between meanings. Views of general submissions were relatively easily quantified, as they responded to a limited number of options.

Research scope also meant it was unfeasible to transcribe all the videos and audio material available. Key sources were transcribed, detailed notes of other were made. Other researchers returning to this topic might choose to go deeper into the data. However, this research had a limited scope and chose breadth and context over depth.

Analysing the sources relating to context were focused on understanding the progression of events, and also on subjectively interpreting how these contextualised the Town Hall advocacy, and how they inter-related. One aspect of qualitative analysis is that the analysis is filtered through the researcher's own frameworks and understandings. This analysis was undertaken with particular understandings of community, participation and participatory practice, and heritage values. These are by no means the only frameworks that can be used on the example, nor are they the most obvious. This research intended to consider an application of these frameworks in an unusual context, and potential impactions for their use in practice. More strictly defined frameworks might have increased the credibility of this analysis but may have reduced the flexibility to broadly analysis the data. ${ }^{55}$

The nature of the interviews also impacted the analysis. As mentioned, the interviews were inconsistent and iteratively developed. This made comparison challenging, and reduced the dependability and confirmability of the overall analysis. ${ }^{56}$ One advantage of this iterative approach to was that it allowed for some respondent validation, as I was able to put my theories to the informants and discuss them from their perspective. ${ }^{57}$ This did allow for some ideas to be discounted or corroborated. However, it only applied at the time of the interviews, and some ideas that were developed later have not gone through that process.

\footnotetext{
${ }^{55}$ Denscombe, 297.

56 Denscombe, 298, 300-302.

${ }^{57}$ Denscombe, 297.
} 
Finally, personal emotional issues impacted this research. As a Christchurch girl born and raised, any Christchurch-focused research I conducted would be touched by some personal connection. At the outset of this research I felt that my personal perspective of Christchurch networks and the earthquake experience would benefit this research. I was entirely mistaken, and found that it warped my perspective. I was constantly analysing and writing about issues within a frame of reference that did not have formal backing. Revisiting the earthquakes years in research meant revisiting them emotionally. This added stress, loss and helplessness to what was already a degrading and tortuous process. I closely identified with many of the opinions of the key informants, and personally respected the efforts of the advocates and urban activists. My own appreciation of the Town Hall has exponentially increased and I have re-evaluated my own relationship with it. My personal experience of Christchurch Christchurch's heritage, politics, planning and rebuild is an integral part of my personal life, and my social circle includes several people connected with the research subject(s), particularly Te Pūtahi. This personal context both has a bearing on my approach to this research, and also in my perspective on wider issues of heritage, urbanism, participation, and social value. 


\section{Post-quake Christchurch: politics, activism and the built environment}

This chapter discusses politics, activism and the built environment in post-quake Christchurch. Post-quake Christchurch was a site of central government control of local politics, devastation to the built environment, grassroots heritage advocacy and notable urban activism. These forces interacted in forming the context of post-quake Christchurch. This chapter primarily focuses on the central city, and on the period 2011-2013. It sets the scene for the Town Hall advocacy that occurred in 2012-2015, discussed in the next chapter. This chapter also examines the interaction of heritage and democracy in the post-quake Christchurch central city. It considers the questions: to what extent were grassroots heritage practices participatory practices, and to what extent were grassroots urban activism projects heritage practices? This chapter is structured in three sections. The political context is discussed first. This primarily relates to the relationship between central and local government, and the implications for Christchurch citizens. The second section discusses grassroots heritage advocacy straight after the February 2011 quake, focusing on the group IConIC. This outlines the heritage advocacy context that preceded the Town Hall advocacy, although it also flags that the Town Hall was not necessarily a representative case of postquake heritage. The final section briefly discusses Christchurch's post-quake urban activism. This demonstrates how some Town Hall advocates were involved in other projects, considers how these projects were developed by a loose community, and considers some of the underlying connections between urban activism and heritage advocacy.

This chapter largely draws on writing by, and interviews with, key advocates of the Town Hall - Jessica Halliday, Barnaby Bennett, and Ian Lochhead. It presents the key advocate's perspective on the Christchurch's post-earthquake situation, rather than a balanced critical analysis of the situation. Perspectives of these three informants refer to interviews unless otherwise stated. A timeline of key events can be found in Appendix 8.1.

\subsection{The political context}

This section explores the politics of post-quake Christchurch, particularly the impact of political forces on re-shaping the central city, and on local democracy. The initial disaster prompted tight executive control by disaster managers. This transitioned into a response controlled by central government through the Canterbury Earthquake Recovery Authority (CERA) and the Canterbury Earthquake Recovery Act (CER Act). Extensive demolition of urban fabric in the central city was driven by safety concerns, insurance, and executive 
authorities' 'blank slate' philosophy. Re-writing of the local central city plan was a key instance of central control of local planning. This plan further threatened the built environment and peoples' sense of representation in the (re)creation of Christchurch. This reduction in local representation, notwithstanding CCC's internal crises, was key to the political and social context on Christchurch, where it seemed that national (New Zealandwide) and National Party policies often had more influence than Christchurch citizens.

Two immediate responses to the February earthquake contextualise later actions and politics regarding the central city. These were the declaration of a national state of emergency, and the establishment of the central city 'red zone' cordon. The national state of emergency gave emergency powers to executive decision makers, primarily Civil Defence under the leadership of John Hamilton. The state of emergency was in place from 23 February - 10 May 2011. The central city red zone cordoned off the city within the four avenues, which was patrolled by the army and had limited access. ${ }^{58}$ The cordon was slowly reduced as buildings were assessed, made safe, or demolished, and was fully removed on 30 June 2013. The state of emergency and the cordon were created in a highly uncertain and safety-conscious disaster situation. Both had long-term impacts on the earthquake recovery. From the point of view of business owners, building owners, and activists, the red zone became a black hole from which it was impossible to gain access, property, or information. ${ }^{59}$ The state of emergency transitioned into an ongoing 'state of exception' where extraordinary powers were vested in executive office. ${ }^{60}$

The CERA and the CER Act were the means by which central government executive authority was applied in Christchurch. CERA was a central government organisation created to oversee the reconstruction process. It was created on 29 March 2011 with a five-year life and was answerable to the Minister for Canterbury Earthquake Recovery, Gerry Brownlee (National MP for Ilam). The CER Act came into effect on 19 April 2011 and was written by the Department of Prime Minister and Cabinet. The CER Act conferred extensive powers on the executive branch of government to enable timely, focused and expeditious decisions for

\footnotetext{
${ }^{58}$ Deans Ave, Harper and Bealey Aves, Fitzgerald Ave, and Moorhouse Ave - the historic core of colonized Christchurch. Not to be confused with the residential red zone came later in a different area for different reasons.

${ }^{59}$ Olivia Carville and Keith Lynch, 'Protesters Breach Cordon', The Press, 22 March 2011, http://www.stuff.co.nz/the-press/news/christchurch-earthquake-2011/4793408/Protesters-breach-cordon. ${ }^{60}$ Jane Smith, 'Christchurch - a State of Emergency', in Once in a Lifetime: City-Building after Disaster in Christchurch, ed. Barnaby Bennett et al. (Christchurch, NZ: Freerange Press, 2014), 145-49.
} 
recovery. It offered no rights of appeal, and protected operatives from liability, thereby overriding many regular New Zealand laws, including the Resource Management Act (RMA). ${ }^{61}$ The RMA is the usual mechanism of planning and environment control in New Zealand (including historic heritage). Thus, the CER Act removed usual processes of planning consent, notification, consultation and appeal to the Environment Court. Many of the functions under the CER Act were ultimately at the discretion of CERA's chief executive and the Minister.

These executive powers facilitated wide-spread destruction of urban fabric in the central city and other parts of Christchurch. Section 38 of the CER Act was a particularly notable part of CERA's power. This allowed CERA to carry out a range of works at will, including demolition of any building or structure. Building owners issued with a section 38 notice had ten days to provide a 'make safe' plan to the CERA chief executive's satisfaction or the building would be demolished at the owner's expense without compensation. CERA was also allowed to demolish a non-dangerous building in order to demolish a dangerous building (although CERA was required to compensate the owner for this). ${ }^{62}$ A significant portion of the central city building stock was demolished under this mechanism.

Insurance was another factor in the widespread demolition in the central city. Rebecca Macfie, a Christchurch reporter, noted: ${ }^{63}$

In California or Japan, where a building might have only $15 \%$ earthquake insurance cover, owners will stand in front of the bulldozers to protect their property ... In contrast, New Zealand property owners have had access to cheap and abundant insurance that - combined with slack regulation of earthquake-prone buildings - has encouraged them to do nothing to strengthen their buildings.

For Christchurch owners faced with the option of repairing damaged buildings or getting an insurance pay-out, there's a powerful incentive to go for the cash.

\footnotetext{
${ }^{61}$ Gerard Cleary, 'Adopting and Implementing a Legislative Framework for Recovery', in Once in a Lifetime: City-Building after Disaster in Christchurch, ed. Barnaby Bennett et al. (Christchurch, NZ: Freerange Press, 2014), 136-37.

${ }^{62}$ Rebecca Macfie, Report from Christchurch, ed. Philip Rainer et al. (Wellington, NZ: Bridget Williams Books, 2013); Cleary, 'Adopting and Implementing a Legislative Framework for Recovery'; 'Canterbury Earthquake Recovery Act' (2011), http://www.legislation.govt.nz/act/public/2011/0012/latest/DLM3653522.html. The CER Act definition of a 'dangerous building' was drawn from the Building Act 2011 as modified by the Canterbury Earthquake (Building Act) Order 2011 (this was in effect for two years from 17 September 2011).

${ }^{63}$ Macfie, Report from Christchurch, chap. 10.
} 
Alberto Amore noted the powerful role that insurance played in the part of heritage, and all buildings in the CBD. ${ }^{64}$ Section 38 exasperated this vulnerability.

By the end of the red zone cordon, about $80 \%$ of the building stock was demolished, including approximately $50 \%$ of the listed heritage buildings ${ }^{65}$ Halliday characterized this as 'urbicide,' a term originally coined regarding destruction in conflicts. ${ }^{66}$ This widespread demolition, not just of heritage places, created a disorientating and painful environment for residents. ${ }^{67}$ In visiting the city, earthquake disaster engineer Kit Miyamoto commented 'In a modern society like this, the taking-down ratio should not exceed $10 \%$ or $20 \%$ maximum. ${ }^{, 68}$ It is unclear whether this was a formal or informal quantification. Either way, it is a wellestablished tenet of urban and heritage theory that rapid changes in the environment are socially unsustainable and that pre-existing environments can be foundations for social recovery from disasters. The urbicide of central city Christchurch offered few such opportunities. A similar situation of emotional devastation in the loss of the built environment occurred in the Residential Red zone. ${ }^{69}$

A key point of power in post-earthquake Christchurch was the control of the recovery plan for the central city. The CER Act required CCC to create a plan for the central city within nine months. This was a tight timeframe by almost any measure. Nevertheless, CCC invited extensive public participation. The 'Share an Idea' campaign was a six-week long engagement process in May and June 2011 that invited citizens to contribute ideas and visions of what they wanted of future Christchurch. This process won international awards and was generally heralded as a high-point in the Christchurch's post-quake planning saga. This engagement fed into CCC's Central City Recovery Plan (usually referred to as the Central City Plan or CCP). The draft was released in August 2011, adjusted following public feedback, and adopted by CCC on 15 December 2011, when it was sent to Minister Brownlee for approval.

\footnotetext{
64 'The Governance of Built Heritage in the Post-Earthquake Christchurch CBD', in Business and Post-Disaster Management: Business, Organisational and Consumer Resilience and the Christchurch Earthquakes, ed. Colin Michael Hall et al. (London: Routledge, 2016), 208.

${ }^{65}$ Jessica Halliday and Paul Walker, 'Heritage, Activism, Architecture' (Melbourne Design Week; Parlour, Melbourne, Aus., 21 March 2018).

66 'Losing Our Collective Memory: The Importance of Preserving Heritage Architecture', in Once in a Lifetime: City-Building after Disaster in Christchurch, ed. Barnaby Bennett et al. (Christchurch, NZ: Freerange Press, 2014), 215.

${ }^{67}$ Macfie, Report from Christchurch.

${ }^{68}$ Macfie, chap. 10.

${ }^{69}$ Macfie, chap. 14.
} 
Under the CER Act, the Minister had final say on the central city plan. On 18 April 2018, it was announced that CERA would revise the plan within one hundred days. The Christchurch Central Development Unit (CCDU) was set up within CERA to achieve this, headed by Warwick Isaacs (formerly in charge of CERA's demolition programme). The CCDU was comprised largely of consultants, with representatives from CCC and Ngai Tahu. The final Central City Recovery Plan (CCRP), also known as the Blueprint was released at a mediaonly event on 30 June 2012. It became law the next day. There was no peer review, public submissions, or revision.

The final CCRP was officially described as a 'revision' of the CCP, but Christchurch citizens and observers generally agree it was a re-write. ${ }^{70}$ CERA's action was largely taken as a rejection of CCC's work. In doing so, it overrode CCC's authority in planning the recovery Christchurch. The CCRP was clearly geared towards international investors rather than local residents. It was written without any public input or review - although CERA insisted that they drew on the 'Share an Idea' data, there was little evidence of this in the final plan. It was also felt that CCRP had largely been motivated by the wishes (and political leanings) of cabinet ministers. A key element of the Blueprint was the seventeen anchor projects, which were to be major works or precincts that would drive the economic recovery of the city. This approach has been widely critiqued from planning and economic perspectives.

A number of commentators have argued that the CCRP disregarded pre-existing structures, systems, and meanings in central Christchurch. It placed new structures over remaining buildings, and in some places overwrote the historic street plan. CERA had the power to compulsorily acquire land and implement further demolition. This threatened heritage building owners who had strengthened their building and wished to retain it. CERA adopted a 'blank slate' approach, assuming that no remaining buildings would lead to a swifter and better recovery. ${ }^{71}$ Another issue was that the Blueprint's rhetoric was intrinsically bound up with politics and the urgency of getting Christchurch 'back to business as usual'. In Bennett's opinion, this left no room for a nuanced debate.

There were other ways in which central government exercised direct control of CCC and local politics. Pre-earthquake, central government undermined the regional council,

\footnotetext{
${ }^{70}$ Barnaby Bennett et al., 'Introduction', in Once in a Lifetime: City-Building after Disaster in Christchurch, ed. Barnaby Bennett et al. (Christchurch, NZ: Freerange Press, 2014), 18-27.

${ }^{71}$ Roger Sutton, 'A Blank Canvass for New Beginnings', in Once in a Lifetime: City-Building after Disaster in Christchurch, ed. Barnaby Bennett et al. (Christchurch, NZ: Freerange Press, 2014), 52-58.
} 
Environment Canterbury, by replacing elected councillors with government-appointed commissioners in May 2010. In July 2013, a government Crown Manager was appointed to manage CCC's building consents, as it had been unable to adequately cope with the number of building consent applications. Another imposition was central government's requirement of a Replacement District Plan (RDP) in July 2014. This was a fast-tracked process that was reviewed by a government-appointed Independent Hearings Panel and government ministers. In February 2015 these bodies publicly criticised the RDP process, particularly expressing concern that development rules could discourage investors. This process also prevented CCC from engaging with the community and key stakeholders. ${ }^{72}$

These critiques of central government control of CCC and other city planning are not to ignore that $\mathrm{CCC}$ was seen as dysfunctional under the Bob Parker mayoralty. Controversies included outrage over the Chief Executive's salary and the building consent crisis. The appointment of the Crown Manager in July 2013 precipitated the Chief Executive's resignation, which in turn prompted Bob Parker's decision not to stand for re-election. CCC was also vastly underinsured for its earthquake damage, and faced a significant funding shortfall by mid-2014. ${ }^{73}$ CCC's image was rehabilitated with the election of Mayor Lianne Dalziel along with nine new councillors in October 2013, the appointment of a new Chief Executive in June 2014, and restructuring in the later part of $2015 .{ }^{74}$

A further political development was the announcement of the Cost Sharing Agreement between CCC and the Crown on 27 June 2013. This clarified which party would pay for (and lead) which Quake recovery projects. The Crown would contribute $\$ 2.9$ billon, and continue to lead many of the anchor projects. CCC would contribute $\$ 1.9$ billion, and was to lead the performing arts precinct (PAP), the new Central Library and the city's car parks, and would share responsibility with the Crown for enhancement of Cathedral Square and a new Central City Transport Plan. ${ }^{75}$

\footnotetext{
${ }^{72}$ Lois Cairns, 'Christchurch City Council Bungled District Plan Review - Report', The Press, 18 November 2015, https://www.stuff.co.nz/the-press/news/74073447/christchurch-city-council-bungled-district-plan-review-report.

${ }^{73}$ Radio New Zealand, 'Christchurch Town Hall Rebuild on Hold', Radio New Zealand, 9 July 2014, http://www.radionz.co.nz/news/regional/249338/christchurch-town-hall-rebuild-on-hold.

${ }^{74}$ Bennett et al., 'Introduction'; Press staff, 'New City Boss Fit and Ready to Go', The Press, 31 May 2014, https://www.stuff.co.nz/the-press/news/10106248/New-city-boss-fit-and-ready-to-go; Ashleigh Stewart and Joelle Dally, '60 Jobs to Go in Major Christchurch City Council Restructure', The Press, 27 August 2015, https://www.stuff.co.nz/the-press/news/71504377/60-jobs-to-go-in-major-christchurch-city-council-restructure. ${ }^{75}$ Christchurch City Council, 'Council and Crown Earthquake Cost Sharing ':, www.ccc.govt.nz, accessed 9 May 2018, https://www.ccc.govt.nz/the-council/plans-strategies-policies-and-bylaws/strategies/christchurchcity-council-and-crown-earthquake-cost-sharing.
} 
Thus, there was a reduction in local representation in two regards. First, CERA overrode CCC removing the democratically elected body's control of the city's future. Second, there was little opportunity for direct participation in planning processes - through submission, consultation and appeal, by which citizens can usually have a say in the transformation of their environments. Citizens responded in demonstrations, in public writings, and indirectly through urban activism, thus influencing the (re)creation of the city on a macro level. However, large sections of the population did not respond to the political situation. In many ways this was symptomatic of the disaster situation, where the loss of representation was seen a necessary for timely and effective response (especially in the initial response). Most Christchurch residents had their own very immediate issue of safety, security, and insurance to deal with. Post-quake Christchurch was an exhausting place to exist, which left little space to respond to the political situation. ${ }^{76}$

The national perception of the Christchurch rebuild was a key factor in post-quake politics. The National Party-led central government's chief accountability was to voters across New Zealand rather than the people of Christchurch. To a certain extent, this meant that the actual situation in Christchurch was less important than national perceptions of progress. Some argued that the national perception never moved on from the initial reaction of supportive sympathy. This became unhelpful when voters failed to understand the state of affairs in Christchurch, including the undermining of local democracy, post-disaster exhaustion, and the character of the rebuild as a reimagining. ${ }^{77}$ The accountability of decision-makers to a non-Christchurch public may be seen as another factor in the removal of representation and the structure of decision-making in post-earthquake Christchurch.

Central government control of Christchurch through CERA meant party politics had significant influence. This is both in terms of party-political factors and party character factors. CERA became intrinsically associated with the National Party. ${ }^{78}$ This was also

\footnotetext{
${ }^{76}$ Macfie, Report from Christchurch.

${ }^{77}$ Barnaby Bennett, 'A Guide to Christchurch Rebuild for the Rest of NZ', Project Freerange (blog), 15 September 2014, http://www.projectfreerange.com/a-guide-to-christchurch-rebuild-for-the-rest-of-nz/; Project Freerange admin, 'Dear New Zealand: This Is on You Too', Project Freerange (blog), 3 September 2012, http://www.projectfreerange.com/dear-new-zealand-this-is-on-you-too/.

${ }^{78}$ Macfie, Report from Christchurch; Barnaby Bennett, 'The Politicisation of CERA and the Planning of New Christchurch', Project Freerange (blog), 6 May 2014, http://www.projectfreerange.com/the-politicisation-ofcera-and-the-planning-new-christchurch/.
} 
expressed in the nature of the decision-making, which appears to have been driven by economists and a focus on international investment. ${ }^{79}$

This is not a comprehensive discussion of the politics of post-quake Christchurch, but it gives some context for environment in which other activities took place, including heritage advocacy, urban activism, and the Town Hall debates.

\subsection{Heritage advocacy}

Amid the loss of urban fabric in post-quake Christchurch, grassroots opposition to heritage loss became a significant undercurrent. This is an important context in which to understand the later, specific heritage debates such as the Town Hall. The demolition of urban fabric corresponded with a loss of heritage buildings. Heritage advocates protested this loss and an advocacy group, Interests in Conserving the Identity of Christchurch (IConIC), formed to try to advocate for the retention of heritage buildings. Despite little definable impact, this citizen advocacy is critical to the context of post-quake Christchurch. It is particularly important context in which to understand the advocacy for the Town Hall, both in terms of the wider context and because key individuals involved in the heritage advocacy were key in the Town Hall advocacy (namely Jessica Halliday and Ian Lochhead). The period of heritage loss and advocacy also contextualises the (evolving) positions of some decision-makers including councillors.

Heritage in post-quake Christchurch was impacted by factors in addition to the wider economic and political factors that fuelled general demolition. For one thing, there appeared to be wide-spread anti-heritage sentiment. ${ }^{80}$ This attitude was driven by central government representatives, particularly Minister Brownlee. Shortly after the February quake, he stated: ${ }^{81}$

My absolutely strong position is that the old dungas, no matter what their connection, are going under the hammer.

There was a genuine public fear of historic structures, and a perception that they presented a higher risk to public safety than other buildings. This was particularly directed at URM buildings that constituted a large part of Christchurch's colonial heritage, especially the revived gothic era. These viewpoints have not been qualified or quantified (to my knowledge). It may have been that most of the population sat somewhere between very pro-

\footnotetext{
${ }^{79}$ Bennett, 'The Politicisation of CERA and the Planning of New Christchurch', Lochhead interview.

${ }^{80}$ Halliday and Walker, 'Heritage, Activism, Architecture'.

${ }^{81}$ Halliday, 'Losing Our Collective Memory: The Importance of Preserving Heritage Architecture', 211.
} 
heritage and very anti-heritage, and were mostly in a state of exhausted apathy, or were concerned with issues that seemed more immediate. Macfie said 'people seem too tired to fight,' and that Christchurch citizens were 'torn between grief for what is lost and an urgent need for progress and hope.' 82

Nevertheless, there were grassroots efforts to encourage retention of heritage and make it part of the recovery strategy. In March 2011 a heritage interest group formed that later adopted the label IConIC. This group was formed largely though personal networks (Halliday). According to Halliday and Lochhead, IConIC included politicians, building owners, architects, engineers, council staff, insurance professionals, building owners, and general citizens. However, professionals attended in a private capacity, which limited their impact. IConIC's strategies mostly aimed to influence decision makers and those in charge of the emergency situation (notably John Hamilton and Gerry Brownlee) through high-level networks, such as by using the politicians as a go-between. One strategy was writing a list of heritage buildings that were a minimum requirement to retain. Ian Lochhead wrote this list largely based on his architectural history expertise, with consideration both for individual buildings and groups of buildings. There was a certain amount of attempting to influence public opinion - Lochhead wrote a substantial number of letters to The Press and IConIC formed a Facebook page mostly for the purpose of spreading information. Thus, IConIC was not a participatory organisation, but it was the formation of a community that attempted to participate in heritage decisions.

Heritage advocacy such as by IConIC was characterised by frustrations and a lack of impact. ${ }^{83}$ According to Lochhead, Minister Brownlee's response to the 'minimum retain' list was that it didn't seem unreasonable, but no action eventuated from it. The demolition of the Cranmer Courts in October 2012 seemed to be a low point in the emotional futility of advocacy, as the demolition went ahead despite a last-minute injunction attempt and a physical protest. ${ }^{84}$

In interview, Halliday stated that it was particularly difficult to advocate in an information vacuum. A variety of building and business owners expressed this frustration. ${ }^{85}$ The political

\footnotetext{
${ }^{82}$ Macfie, Report from Christchurch, chaps 5, 9.

${ }^{83}$ Halliday and Walker, 'Heritage, Activism, Architecture'.

${ }^{84}$ Michael Wright, Joelle Dally, and Anna Turner, 'Protester Arrested at Cranmer Courts Demolition', Stuff.Co.Nz, 4 October 2012, sec. Christchurch Earthquake 2011, http://www.stuff.co.nz/thepress/news/christchurch-earthquake-2011/7766034/Protester-arrested-at-Cranmer-Courts-demolition. 85 Carville and Lynch, 'Protesters Breach Cordon'; Macfie, Report from Christchurch.
} 
environment created by the national emergency and the CER Act removed all the normal mechanisms that allow for community push-back against heritage decisions (Lochhead interview, Macfie 2013). To Halliday's mind, it was particularly frustrating that no middle ground was offered between the normal processes - which were indeed lengthy, costly, and often frustrating - and the executive power model employed. This was applicable to wider urbanism interests rather than just heritage. Halliday articulated that this was not just frustration about the inability of citizen to impact decisions, or regard for the wider sociocultural impacts. It was also the completely closeted nature of decision-making which made it impossible for interested parties to assess how and why decisions were being made, or by whom.

There were certainly different views on potential futures for Christchurch's heritage. Katie Pickles, a historian from University of Canterbury, argued that Christchurch should use the earthquakes to break away from its prevalent narrative of colonial and conservative history. ${ }^{86}$ The most prominent 'heritage battle' in post-quake Christchurch was the Christchurch Cathedral, which was driven by an organisation largely separate to the IConIC. This had a very different character to many other Christchurch heritage issues. Heritage advocacy was fragmented and controversial.

There were some positive heritage stories, most notably the Arts Centre and the Isaac Theatre Royal. These cases provide counter-points that help understand influences on the loss of heritage. Primarily, both of these examples demonstrate that determined leadership and financial backing were essential. Both of these sites have subsequently become anchors in the recovery. Amore identified a number of factors that assisted the Arts Centre, including better access, independent engineering advice, early and subsequent insurance pay-outs, wide fundraising and a firm managing vision to re-build with high heritage values. ${ }^{87}$

In conclusion, post-earthquake Christchurch was a site of both heritage (and urban fabric) loss and heritage advocacy. It is possible to say that heritage was both a motivation and an arena for push back against the political context of reduced local control in post-quake Christchurch. Despite the apparent lack of success at the time, Halliday reflected that it may not have been a complete waste of time. This heritage advocacy is important context in which to consider the later advocacy for the Town Hall.

\footnotetext{
${ }^{86}$ Katie Pickles, Christchurch Ruptures, BWB Texts (Wellington, NZ: Bridget Williams Books, 2016).

${ }^{87}$ Amore, 'The Governance of Built Heritage in the Post-Earthquake Christchurch CBD'.
} 


\section{$4.3 \quad$ Urban activism}

Various grassroots urban activism or 'civic innovation' projects were another notable feature of post-quake Christchurch. There are two reasons to consider these projects. Many of these projects can be characterised as participatory and/or transitional and were primarily peoplefocused. I was initially interested in potential connections between the participatory practices and heritage advocacy practices. Ultimately, there were no explicit connections but there were some common philosophies. These include the formation of communities through personal networks, and an interest, involvement, and experience in issues of urbanism, architecture, planning.

Gap Filler and Greening the Rubble were two urban activism projects that developed following the September 2010 earthquake. These projects were both focused on making fun, exciting and welcoming spaces out of vacant sites and quake damage. In Jessica Halliday's memory these early initiatives helped create an environment of creative urban experimentation: ${ }^{88}$

These things were all happening together and the same time - Gap Filler, Greening the Rubble, a whole lot of momentum around temporary activity and artists and others getting interested in that - everyone from performance artists to Rotary were wanting to do temporary projects in public spaces or on vacant sites...

This experimental momentum continued after the February 2011 quake. Personal networks developed in the post-quake environment, as Halliday recalled: ${ }^{89}$

... all of a sudden ... most of the places where most people come together bars, restaurants, theatres, cinema, concert halls, music venues, central library - these are all gone. You had to start to invent your own cultural and social life using whatever infrastructure you've got and whatever means you've got. There was a group of us who were regularly meeting ... in our home[s], we ... started calling it 'family dinner,' ... we were a bunch of people who felt like something ... bigger needed to be done....

These 'family dinners' led to the development of a Festival of Transitional Architecture (FESTA) in 2012. Again, this came together from individuals from different backgrounds, including theatre, futurism, and architecture, with Halliday acting as director. This became a week-long event conducted on the edge of the city cordon. It was the first time people had

\footnotetext{
${ }^{88}$ Halliday and Walker, 'Heritage, Activism, Architecture'.

${ }^{89}$ Halliday and Walker.
} 
been invited back into/near the central city since the earthquakes. ${ }^{90}$ FESTA was repeated in 2013, 2014, and 2016, each year with a different theme and headline event.

Some of these projects transitioned towards more long-term enterprises. Gap Filler expanded into Life in Vacant Spaces, which used the skills gained through Gap Filler to assist small and temporary enterprises to occupy temporary sites. FESTA, while ongoing, developed into Te Pūtahi (the Christchurch Centre for Architecture and City-Making), which focuses 'on the current rebuild and on-going renewal of our city for the long term.' They continue to use the experience of creative community members to "creatively engage a wide range of stakeholders and users with the making of a better city. ${ }^{91}$ Te Pūtahi's practice evolved as different people came on-board as Halliday noted that Anne Cunningham enabled more explicitly participatory practice.

There is a question of the extent to which these projects responded to the political environment as much as the physical environment. This research is insufficient to generalise for all of the urban activism projects. However, Halliday did see FESTA and related projects as responses to the political situation: ${ }^{92}$

It's about defiance against the situation and context. ... And right now [these projects are] one of the few ways that quite ordinary citizens can feel part of the remaking of the city. Because a lot of the time we feel we haven't been invited in and consulted and we haven't been part of the process. So this is our way of saying, actually, we are part of the remaking of the city whether you officially ask us or not.

When read through a heritage lens, many post-quake projects might seem to have an element of memory or meaning re-creation from pre-existing sense(s) of place. ${ }^{93}$ However, Halliday and Bennett stated that they did not regard their temporary practices as heritage practices. Indeed, when asked about how urban activism considered pre-existing meaning, Bennett responded it was one level of the practice but that 'there was a desire from lots of quarters to change it [Christchurch] towards a better version of what it could have been.' He continued he thought a strong alliance between a wide variety of philosophies that did not align on all

\footnotetext{
${ }^{90}$ Halliday and Walker.

91 Te Pūtahi, 'About Us', accessed 9 May 2018, http://teputahi.org.nz/about-us/.

${ }^{92}$ Halliday quoted in Rebecca Macfie, 'Shock of the View', in Once in a Lifetime: City-Building after Disaster in Christchurch, ed. Barnaby Bennett et al. (Christchurch, NZ: Freerange Press, 2014), 375.

${ }^{93}$ Barnaby Bennett, Eugenio Boidi, and Irene Boles, eds., Christchurch: The Transitional City, Pt. IV.

(Wellington, NZ: Freerange Press, 2012).
} 
issues developed because they were against 'generic urbanism' in post- (and pre-) quake Christchurch.

Therefore, while acknowledging that not all heritage and urban activism agendas directly aligned, I would suggest that was some connection in their underlying philosophies. Individuals in the urban activism community came from a wide range of backgrounds, including performance, visual art, landscaping, architecture, art history, and design. Though apparently diverse, these perspectives are all concerned with notions of urbanism and place. One project leader stated that the language of performance studies: ${ }^{94}$

$\ldots$ is the same language as urban design and architecture - it's how people interact with and move through space, and how space performs and how it causes you to perform.

These are all notions unpinning ideas of heritage, and the roles of heritage in broader places. Bennett supported the idea of an underlying connection between temporary urban activism and heritage, saying:

... it almost sounds contradictory, that a group of people who are interested in these completely ephemeral, light-weight, come-and-go, meanwhile sort of things, are also the same group that was interested in the really long-term, serious sort of heritage in the city, but it doesn't take much picking to realise that actually makes complete sense. [Those groups are both] interested in non-financial priorities like cultural values and things beyond immediate measures of efficiency and bringing people together and working on projects and the arts and creativity and all that stuff.

\subsection{Summary}

This section set out a few critical aspects of the context of post-Christchurch. The political context was largely that the local council was superseded by central government organisation CERA, reducing local input and local considerations in planning the rebuilding of Christchurch. This, as well as other factors, influenced extensive demolition of both heritage and non-heritage buildings, particularly in the central city. Heritage advocacy efforts responded to. The strategies and frustrations of these efforts provides context to ongoing efforts, particularly regarding the Town Hall. Urban activism projects were also part of the context of post-quake Christchurch. These projects created exciting, playful, and resilient responses to the physical environment of post-quake Christchurch, and responded to the political environment to some extent. Though they were not heritage practices, they could be

${ }^{94}$ Coralie Winn in Macfie, Report from Christchurch, chap. 13. 
seen has having similar relations with ideas of urbanism, place, and potential to contribute to socially resilient cities. These three contexts all have a bearing on the advocacy Town Hall, as the next chapter discusses. 


\section{The Christchurch Town Hall: Process, opinions, outcomes}

This chapter is about debates of the Christchurch Town Hall 2011-2015. Demolition of the Christchurch Town Hall became a possibility in city planning documents in mid-2012 following damage in the February 2011 earthquake. A group responded with an advocacy campaign, using CCC ownership of the Town Hall as a platform. This advocacy created expressions of heritage value which as the core data for this analysis. The Council voted in favour of restoration three times, in 2012, 2013 and 2015. These debates were accompanied by public debate in media, and by multiple council plan processes.

This chapter narrates key events related to the Town Hall debates. It then discusses the advocacy strategy of the Keep Our Town Hall (KOTH) group. The advocacy consisted of different forms of representation to Council, which are analysed for the values they expressed. The analytical framework considered the typology of values expressed, particularly informal personal and social values. The analysis frames these through the different 'communities of interest' and the specific processes that produced them. Finally, this chapter considers the impact of the advocacy and the factors in the final decision to restore the Town Hall. It concludes that the Town Hall issue was tied up with wider issues, and that the advocacy was not itself participatory, but was a form of participation in the heritage-making process.

\subsection{The Christchurch Town Hall}

The Christchurch Town Hall is Christchurch's primary concert hall and performance venue. The 1972 brutalist complex sits in central Christchurch just north of the Avon River and Victoria Square, along Kilmore St from Colombo St. Its main spaces are the auditorium (later called the Douglas Lilburn auditorium), the James Hay Theatre, the foyer space, the Boaters Restaurant, the Limes room, and the Cambridge room. The Ferrier Fountain is outside. These spaces had a variety of civic, performing arts, community and corporate uses.

The Town Hall originated out of a long-running struggle to build an adequate concert hall in Christchurch. ${ }^{95}$ This included extensive public fundraising. An international design competition was used to create the design, one of the most significant to occur in New

\footnotetext{
95 W. J. A. (William James Arnold) Brittenden, A Dream Come True: The Christchurch Town Hall (Christchurch, N.Z.: Christchurch Town Hall Committee, 1972).
} 
Zealand. ${ }^{96}$ Christchurch firm Warren and Mahoney created the winning design. The architectural partnership of Sir Miles Warren and Maurice Mahoney was and remains one of the most highly revered in the New Zealand.

Their design created a horse-shoe (oval) auditorium. This created an intimate experience with good sightlines which made the audience feel involved with the performance. However, normal horseshoes create terrible acoustics. The acoustics were designed by Harold Marshall, an architect, scientist and musician (originally from Auckland) who used his research of acoustics and lateral reflected sound to create the precisely adjusted panels, and raised the room, which created a 'room within a room'. This created excellent acoustics for almost every seat. It took some tweaking, and arguably the addition of the Rieger organ in the 1990s, to perfect the acoustics. This is normal in acoustics, and the Town Hall is regarded as a landmark in the development of concert hall design. Hence the Town Hall is said (by advocates) to have solved the problem of the horse-shoe auditorium. The Town Hall was also a landmark building for the contractor Charles Lundy, a prominent Christchurch builder. By 2010, the Town Hall had been linked to the Convention Centre by a sky bridge across Kilmore St. Before the earthquakes, plans were underway for a physical renovation, particularly focused on improving the backstage facilities. It was (and remains) a Group 1 registration on the CCC Heritage List. Unusually, its listing includes its interior. It was not listed by HNZPT.

\subsection{Narration of the Town Hall events 2011-2015}

The Council voted to fully restore the Town Hall three times, in November 2012, August 2013 and June 2015. These decisions happened in the context of CCC's strategic and financial planning processes. These were the platform for general submissions and advocacy submissions. The committee and Council meetings (after July 2012) discussed here all heard deputations on the Town Hall. Notable political events were the CCRP release in 2012, and the CCC/Crown Cost Sharing Agreement and the change in council in 2013.

\footnotetext{
${ }^{96}$ Miles Warren, Miles Warren: An Autobiography. (Christchurch, N.Z.: Canterbury University Press, 2008); Ian Lochhead, 'Let Our Public Living Room Live Again', The Press, 20 March 2012.
} 


\subsubsection{Origins of the Town Hall debate, February 2011 - July 2012}

The threat of full or partial demolition of the Town Hall developed in early 2012. After the February 2011 earthquake, the Town Hall was within the Red Zone cordon. In March 2012 Ian Lochhead published an opinion piece in The Press, in which he coined the phrase 'Christchurch's public living room,' and argued for speedy restoration. ${ }^{97}$ However, he did not include it on IConIC's list of 'minimum retain' heritage because at that stage it was not felt that the Town Hall was at risk.

The Town Hall had featured positively in the draft Central City Plan (CCP) created with public input by CCC in 2011. The CCP indicated that CCC was committed to retaining heritage places where possible, and in retaining the Town Hall as Christchurch's premier performance venue, although further assessment and decision-making would be required. Holmes Consulting Group reported to CCC on structural damage to the Town Hall in August 2011.

Two key documents from early and mid-2012 indicated that the Town Hall was at risk. These were the draft CCC Annual Plan 2012/13, released for consultation in April 2012, and CERA's CCRP, released in July 2012.

The draft Annual Plan 2012/13 proposed options for rebuilding major community facilities, including the Town Hall. It acknowledged the significance of the Town Hall to Christchurch, as a performance venue and a place of fond memories, and as a historically and acoustically significant building, and briefly described the physical damage. The options presented were:

1) Repair existing facility to $100 \%$ NBS (including demolishing and rebuilding the Cambridge Room).

2) Rebuild like for like

3) Rebuild a new Town Hall as a new iconic design

4) Repair existing facility to $100 \%$ NBS but demolish and not replace Limes and Cambridge rooms

The final Annual Plan 2012/13, adopted on 26 June 2012, showed that the Council was seriously considering partially demolishing the Town Hall, as the Plan stated:

Staff were asked to evaluate the merits of retaining the main auditorium and developing a new entrance and gathering space provided overall acoustic

\footnotetext{
${ }^{97}$ Lochhead, 'Let Our Public Living Room Live Again'.
} 
quality and sense of place can be retained. Budget of $\$ 127.5$ million over four years was set aside for the rebuild of the Town Hall and the Council acknowledged the involvement of the CCDU and arts community going forward. Insurance contribution is estimated at \$68.9 million.

Furthermore, Council meeting minutes (25 June 2012) show that a councillor moved 'That the Town Hall be demolished in its entirety and rebuilt on a new site.' This amendment was lost 13 votes to 1 . However, it indicates the jeopardy for the Town Hall's full retention on its original site. ${ }^{98}$

The draft Annual Plan 2012/13 became a basis for the public discourse on the Town Hall. The public submissions on the plan and subsequent public discourse shows that the options were taken as definitive. The costings presented for each of the options (CCC Draft Annual Plan 2012/13, 16) were often quoted until mid-2015. The cost of repairing the existing Town Hall was largely accurate (\$120.2 million against a 2015 estimate of \$127.6 million). Other figures would largely turn out to be false. Particularly, the cost of building a new facility was significantly under-estimated and the Annual Plan 2012/13 projected that CCC would receive a full insurance pay out for any of these options. As will be discussed later, this would critically turn out to not be the case.

The next, more significant, document threatening the Town Hall was the Central City Recovery Plan (CCRP), released on 30 July 2012. Its only reference to the Town Hall was in the context of the Performing Arts Precinct (PAP) to be located around the Isaac Theatre Royal. The plan stated: 99

The precinct designation will be sufficient to provide for a range of facilities in the event that the Town Hall cannot be repaired.

This wording would be seen as critical in the future debate about the Town Hall and its relationship with the PAP. The Town Hall was visually absent from the Blueprint. The whole block on which it stands (Columbo St/Kilmore St/Durham St/Armagh St) was transformed into an 'urban gateway' with little built coverage (see Figure 1). ${ }^{100}$

\footnotetext{
98 This was the only Council or committee meeting mentioned here that did not hear advocacy deputations.

${ }^{99}$ Christchurch Central Development Unit, 'Christchurch Central Recovery Plan' (Christchurch Central Development Unit, 30 July 2012), 77.

${ }^{100}$ Christchurch Central Development Unit, 35-36. It should be acknowledged that Ngāi Tahu representatives had some input into the Blueprint. Victoria Square and the Christchurch Town Hall are sites of importance and historical colonialism to Ngāi Tahu. Ngāi Tahu may have preferred the clean slating of this block.
} 

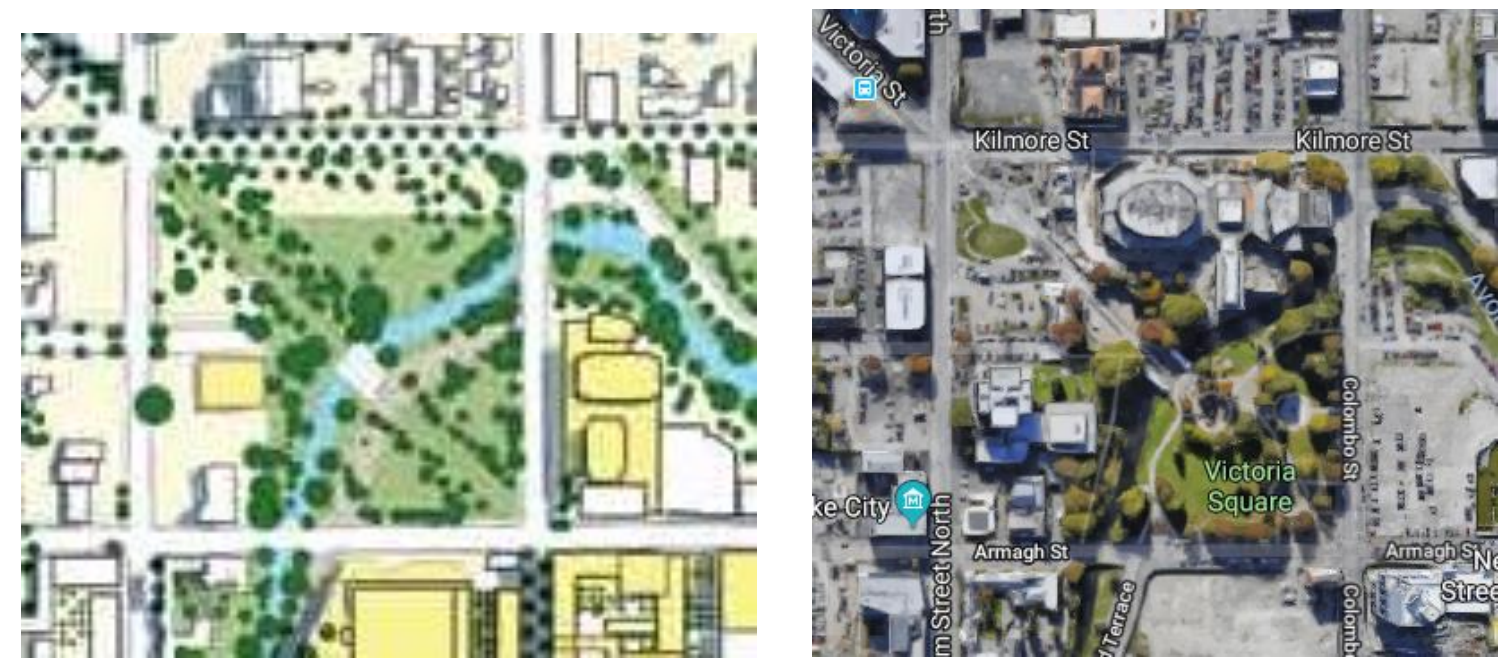

Figure 1: The Victoria Square block in the CCRP Blueprint (left) ${ }^{101}$ where is has been turned into an Urban Gateway, and $\underline{\text { the same block (right) }{ }^{102} \text { showing the location of the Town Hall. }}$

This threat to the Town Hall became the impetus for the development of the grassroots campaign to retain the Town Hall, particularly the formation of KOTH. The Town Hall's perceived risk was increased by Minister Brownlee's negative statements about it, as Lochhead said:

It was only after CERA developed its 100-day plan that it became apparent that the Town Hall was at risk, and the minister was quite vocal in stating that it needed to come down.

\subsubsection{Up to the first Council Vote, August - November 2012}

As a preliminary to the full Council considering the Town Hall, the Community, Recreation, and Arts Committee (CRAC) considered deputations and the staff report on 30 October 2012. The staff recommendation was that the auditorium be retained but the rest be demolished. However, the CRAC voted that a full restoration be recommended to Council.

An example of central pressure on CCC occurred in the lead-up to the Council's first vote on the Town Hall on 22 November 2012. On 14 November 2012 Gerry Brownlee gave an interview on NewsTalkZB during which he argued that the Town Hall should go. Barnaby Bennett responded to this on Project Freerange on 15 November, republished on the local news website Scoop. ${ }^{103}$

\footnotetext{
${ }^{101}$ Christchurch Central Development Unit, 34.

102 Google Earth, April 2018

${ }^{103}$ Barnaby Bennett, 'This Isn't about the Christchurch Town Hall', Project Freerange (blog), 21 June 2013, http://www.projectfreerange.com/this-isnt-about-the-christchurch-town-hall/.
} 
Nevertheless, the Council unanimously voted to restore the 'existing facility' to $100 \%$ NBS on 22 November. However, they chose to explore 'opportunities to rework the southern entry to the Town Hall from the Avon River Park which may mean some changes to Boaters, the Limes and Cambridge rooms.' The minutes noted the 'overwhelming majority of submitters to the draft annual plan were in favour of this option,' and agreed 'with the heritage advice that the sense of place would be compromised if only the auditorium is retained.' ${ }^{104}$

This became the first 'save' for Town Hall advocates. The minutes indicate the impact of both the submitters and the staff report on heritage values. However, it was not the final decision, and the debate would continue to develop.

\subsubsection{Up to the second Council Vote, November 2012 - August 2013}

Developments following the Council's first vote to retain the Town Hall indicate the conflicts between CCC's commitment to the Town Hall and CERA's intentions for the PAP. Internal CERA communications (released to Bennett under the OIA) show that CERA staff were concerned that the PAP would have reduced ability to function as a hub, and also that CCC would be able to contribute less financially to the PAP if they were paying for a full restoration of the Town Hall. This appears to have been based on an understanding that insurance money from the Town Hall could be transferred to the PAP. It is unclear where this understanding came from, as by 2015 it proved to be incorrect. The CCC draft Annual Plan 2012/13 may have been one origin, as this stated that there would be a full insurance pay-out in any situation. As Bennett discussed, it is not publicly known whether CERA received legal or engineering advice about the Town Hall.

The Cost Sharing Agreement between CCC and the Crown (signed 27 June 2013) appears to confirm that the Town Hall retention interfered with the PAP. The Cost Sharing Agreement stated the Council would lead the development of a new performing arts precinct near the Theatre Royal 'as a result of the Council's proposal to save the Town Hall.' ${ }^{105}$ This is an indication of how the Town Hall issue became a 'proxy-battle' between CCC and CERA.

\footnotetext{
${ }^{104}$ Christchurch City Council, 'Minutes of a Meeting of the Christchurch City Council Held at 9:30am on Thursday 22 November 2012' (Christchurch: Christchurch City Council, 22 November 2012), 2, http://resources.ccc.govt.nz/files/TheCouncil/meetingsminutes/agendas/2012/November/Council_22Nov2012Co nfirmedMinutes.pdf.

105 'Council and Crown Earthquake Cost Sharing', Christchurch City Council Website, accessed 20 April 2018, https://www.ccc.govt.nz/the-council/plans-strategies-policies-and-bylaws/strategies/christchurch-city-counciland-crown-earthquake-cost-sharing/.
} 
Bennett articulated this view in a blog article discussing the Town Hall as a conflict over the CERA-led, anchor-project driven recovery of Christchurch. ${ }^{106}$

CCC was also developing a Three-Year Plan 2013-2016 during the first half of 2013 (this was a post-earthquake anomaly in the council's planning process). ${ }^{107}$ This was closely tied-up with the negotiation of the Cost Sharing Agreement, and the Three-Year Plan was adopted the day after the Cost Sharing Agreement. The Three-Year Plan presented the Town Hall repair as one of CCC's priorities among the major facilities rebuild projects and did not present options.

The Cost Sharing Agreement required CCC to reach a final decision about the Town Hall and PAP within a matter of months. This created a heated public debate over the two issues. KOTH sent a letter to supporters on 27 August 2013 stating that they thought that The Press had been running an 'extraordinary campaign' in favour of full or partial demolition of the Town Hall. They felt they had not been able to gain the same platform and as such were asking for further messages of support in the face of 'the very real possibility of losing the vote'. 108

Staff reports on options for the Town Hall were presented to Councillors in a workshop in mid-late July or early August 2013. The CRAC considered the Town Hall again on 23 August 2013. Media and councillors toured through the Town Hall on 28 August. ${ }^{109}$ The next day, the Council again considered the Town Hall, hearing deputations from KOTH and performing arts professionals. The Council again unanimously voted to fully restore the Town Hall. According to the minutes the resolution was to commence design development to achieve further cost certainty through a tender process and greater understanding of functional requirements from user groups. Minutes also state the option was 'recommended based on the balance of strong heritage support and limited functionality and commercial benefits of the other options.' This vote included confirming the elements of the PAP, including the Town Hall, and committed to a feasibility study with stakeholder engagement. The Cost Sharing Agreement placed requirements on the brief and project definition. The

\footnotetext{
${ }^{106}$ Bennett, 'This Isn't about the Christchurch Town Hall'.

${ }^{107}$ Christchurch City Council, 'Three Year Plan 2013-16', Christchurch City Council Website, accessed 24 May 2018, https://www.ccc.govt.nz/the-council/plans-strategies-policies-and-bylaws/plans/long-term-plan-andannual-plans/older-plans/three-year-plan-2013-16/.

${ }^{108}$ Barnaby Bennett, 'Keep Our Town Hall Again', Project Freerange (blog), 27 August 2013, http://www.projectfreerange.com/keep-our-town-hall-again/.

${ }^{109}$ Christchurch City Council, Media Tour of the Christchurch Town Hall - 28 August 2013, 2013, https://www.youtube.com/watch?v=_NPE-oPs-Y8.
} 
Council also voted (9 votes to 4 ) to create budget assurance by separating the Town Hall (\$127.5 million) and the other Performing Arts Precinct facilities (\$30 million plus partner contributions).

The financial issue, particularly the insurance pay-out became a significant point of contention in the Town Hall debates. The Press and proponents of the PAP continually argued that a full Town Hall insurance pay-out would be transferable. This emerged as a fallacy by 2015 and was a key point in supporting the full retention of the Town Hall.

\subsubsection{Up to the third Council vote, October 2013 - 11 June 2015}

Two major developments were the change in council in October 2013, when Lianne Dalziel became mayor, and the Council's significant funding shortfall, publicised in mid-2014. Lianne Dalziel was a former Labour MP for Christchurch East, which had been hard-hit by the quakes, and was elected along with new councillors and only four incumbents. ${ }^{110}$

Plans for the Town Hall were released in November 2013 and public workshops were held, primarily with user groups. However, in July 2014 it was announced that the restoration of the Town Hall was on hold due to financial issues and that the "council was waiting to clarify its insurance position before proceeding., ${ }^{111}$

The Council continued to seek cost certainty for the Town Hall restoration by calling for expressions of interest in September 2014, meaning it undertook a tender process to find a contractor.

The Town Hall was next considered by Council in the context of the Long-Term Plan 20152025. This was the first Long-Term Plan review since the earthquakes. The big issue was a $\$ 1.2$ billion funding shortfall, which necessitated controversies such as asset sales and rates increases. Public consultation on the Plan occurred in March and April 2015. There were no explicit options on the Town Hall as presented in the 2012 Annual Plan, although costings for the restoration were presented. ${ }^{112}$

A key factor for the final Town Hall vote was the creation of a strategic and economic business case by Deloitte consultants. Five options around the Town Hall were considered,

\footnotetext{
${ }^{110}$ Bennett et al., 'Introduction', 21.

${ }^{111}$ Radio New Zealand, 'Christchurch Town Hall Rebuild on Hold'.

${ }^{112}$ Christchurch City Council, 'Smart Choices 2015-2025 Christchurch City Consultation Document' (Christchurch, NZ: Christchurch City Council, 10 March 2015), 47, http://www.ccc.govt.nz/assets/Documents/The-Council/Plans-Strategies-Policies-Bylaws/Plans/Long-TermPlan/draft2015/CCCLTPConsultationSummary201525.pdf.
} 
including costs, insurance pay-outs and costs to council (see Table 2 in appendix). The business plan connected these options with CCC's vision for a vibrant and liveable Christchurch, which meant the city needed a variety of fit-for-purpose civic, cultural and performing arts facilities. The business case concluded that 'do nothing' was not an option and that a new facility was not affordable. It recommended the full restoration of the Town Hall as the most cost-effective option to achieve the strategic cultural goals, given that the auditorium was world class. It allowed for the James Hay to be reconfigured to better suit user needs.

The final Council vote on 11 June 2015, following deputations the previous day, was 12 to 1 in favour of restoring the Town Hall.

\subsection{Keep Our Town Hall campaign and other Town Hall advocacy}

The Keep Our Town Hall campaigners were Sir Miles Warren, Sir Maurice Mahoney, Prof. Ian Lochhead, Dr. Jessica Halliday, Barnaby Bennett, and Duncan Craig. They were assisted by Sir Harold Marshall and Dr. Lynne Lochhead. All the advocates brought their experience and credentials to bear on their advocacy; Warren and Mahoney were particularly renowned and respected individuals (the impact of this is discussed later).

Each of the KOTH campaigners had an association with the Town Hall. For Warren, Mahoney and Marshall, it represented a significant moment in their careers (Halliday, Lochhead, Warren 2008). Halliday intimately knew and loved the building, having co-written a conservation plan for CCC in 2009. Bennett has a personal connection through his grandfather, which he discussed in our interview and in his support letter in 2012.

KOTH came together through personal networks in mid-2012. Halliday recalled that the KOTH core's initial reaction to the threat to the Town Hall was 'No, this one we have to save.' Nevertheless, their advocacy losses through 2011 meant they were apprehensive about their ability to save the Town Hall. ${ }^{113}$

KOTH had a strategic approach which focused on persistently delivering solid, consistent arguments in direct representations to Council. CCC ownership of the Town Hall was critical as it created this platform. Their strategy had two key elements: gathering letters of support to present to Council, and deputations to council.

${ }^{113}$ Halliday and Walker, 'Heritage, Activism, Architecture'. 
KOTH directly solicited letters of support for the Town Hall. They focused on contacting architects and musicians with known connections to the Town Hall. They particularly utilised personal and professional associations of Warren, Mahoney, Lochhead, and Marshal, but also went outside personal networks. A collated volume of submissions was submitted to the CRC Committee and the Council in 2012, although letters were also sent directly to councillors. This collected 59 individual submissions, (including letters by four KOTH campaigners). Cosigning of letters and additional deputations by Halliday and Sir Marshal meant that in total KOTH submissions represented the opinions of 211 individuals. The letters are mostly from September and October 2012, with two written in August and one in May 2012.

Most of the supporters were experts in their own fields (mostly architecture, acoustics, and music), often writing in official capacities and representing organisations. Geographically the letters were local, national, and international. A full list of support letters is presented in Appendix 8.3.

The compilation of the KOTH submissions contains a preface by the six KOTH organisers. It also contains a copy of a letter that KOTH sent to potential supporters. This letter prefaces many of the Town Hall's key values, specifically its architectural, acoustic, and civic values. This letter demonstrates that this was not a neutral research project but an advocacy project, intent on collecting and arguing positive and important aspects of the Town Hall.

The KOTH strategy did not involve general public participation. When asked, Halliday suggested that they had considered a broader public campaign, involving social media, but decided against it. She stated that it would have been too much effort, noting that in such a campaign there is a need to negotiate opinions, respond to enquiries, stay on top of public relations and so on. I would assess this as reflecting KOTH's strategy of running a concerted, focused campaign that did not allow for negotiation of the value of a building they felt was critically important.

Deputations on the Town Hall were made to CCC by KOTH and by other advocates five times between 2012 and 2015 (see Table 1 in Appendix 8.2). The Friends of the Town Hall Organ Trust made a deputation to the CRAC in 2012. In 2015 deputations were made by Don Wheelan, representing a number of music teachers and associated organisations; Graeme Wallis and Margaret Austin, representing Voice Christchurch and the Christchurch Civic Music Council (groups formed by the local music communities) and Martin Setchell, curator of the Town Hall organ. These deputations followed the themes of other advocacy but had 
particular emphasises (discussed below). In 2013 deputations were made by representatives of the performing arts sector, as the Council was considering the Town Hall in conjunction with the PAP. These submissions (by Luke di Somma, Neil Cox, and Gretchen La Roche) have not been able to be analysed as they were not included in the LGOIA release from CCC, although news reports suggest they did discuss the Town Hall.

Deputations did not significantly change over the five deputation occasions. Minor details changed in response to developments such as new reports and commentary. Recordings only exist for the deputations to the Council in 2015, and therefore the only ones which can be analysed verbatim. This may mean that the analysis is skewed in their favour. The same is true of the council debate and decision.

\subsection{Advocacy for the Christchurch Town Hall, 2012 - 2015.}

\subsubsection{Description of advocacy value expressions}

Advocacy for the Town Hall expressed a range of architectural, technical, civic, and 'sense of place' values. Figure 2 shows the key categories of meaning, with sub-elements, that were analysed from the representations. This section describes these categories in more depth. The next sections discuss the intertwining of meaning, and the ways 'communities' can be read into expressions. While most of the letters were highly expressive, some values statements were very short and were limited to 'outstanding' or 'iconic'. Two supporters effectively sent the original KOTH letter under their own name. 


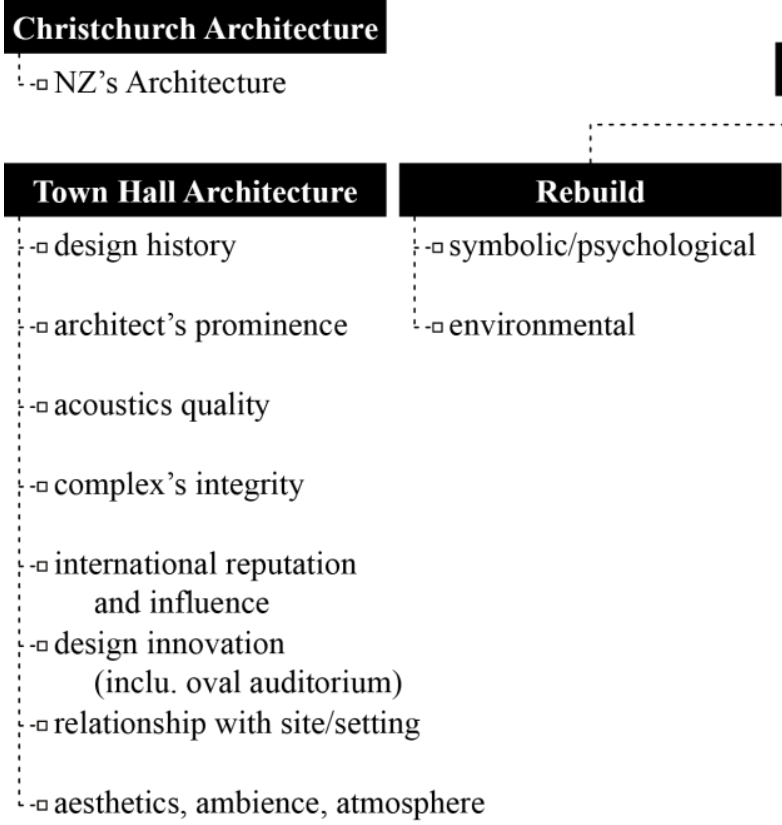

Replacement Uncertainty Christchurch Urbanscape
Contemporary Christchurch

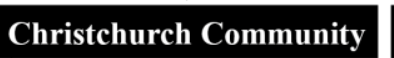

-aidentity

-apride

- aarts

-םcivic "living room"

- -ownership

\section{Personal Connection \\ - relationship to Christchurch \\ - visitor \\ - native}

- professional

- musical/performance

- design

${ }_{-\square \text { specific emotions }}$

Figure 2: Structure of meanings of value expressions in Town Hall advocacy submissions.

\subsubsection{Architecture}

Elements of architectural value expressions, as listed in Figure 2, could be read at face value. The analysis also read implicit meanings in these statements. For example, arguments about the history of the design, particularly the famous design competition, positioned the Town Hall as significant for the architectural profession in New Zealand. The statements about the prominence of Sir Warren or Warren and Mahoney had dual meanings: the architect(s)' calibre and reputation were used as evidence of the building's value, and as a reason unto itself for the building's retention. Several writers, especially Lochhead and KOTH, argued that the Town Hall is the only New Zealand building that has had an international influence. Explanations of the significance 'solving' of the acoustic problem of oval auditoriums implicitly argued that the city and Council should recognise the prestige of the technical significance.

The integrity of the complex featured inconsistently. KOTH was particularly campaigning for the retention of the whole complex, rather than just the auditorium. Many supporters, predominately those with an architecture/design background, supported this by writing about the integrity of the complex and the relation of the components to each other. However, 
several supporters just wrote about the auditorium. Musicians in particular focused only on the auditorium.

The value of the Town Hall was also expressed in relation to wider Christchurch architecture and urbanism. These arguments expressed the significance of Town Hall in the context of architectural history, pointing out the local and national significance of the mid-century 'Christchurch school.' Arguments also discussed Christchurch's present and future urbanism, with writers stating how important heritage and diverse architecture should be in the Christchurch rebuild.

\subsubsection{Replacement uncertainty}

A 'replacement uncertainty' argument was actively mobilised by advocates with design backgrounds. I use 'replacement uncertainty' to formalise the notion that heritage advocacy can be motivated by a fear or lack of faith that the replacement will be better than the building that is already there, even with its acknowledged faults. ${ }^{114}$ Advocates explicitly articulated the low probability that anything nearing the quality of the Town Hall could be rebuilt, particularly regarding the acoustics. Supporters and especially KOTH deputations used the Town Hall's history and technical significance to demonstrate that the Town Hall resulted from a rare 'perfect storm' of fortuitous factors. This was not a 'value category' as such. Rather, it shows that much of the advocacy positioned itself in terms of potential alternatives, which is not a function of formal heritage frameworks.

\subsubsection{Christchurch community}

'Christchurch community' was a key theme of value expressions. These comments were largely associated with theoretical social value: they expressed how the Town Hall was valuable to the Christchurch community, and hoped form the identity of being a Christchurch citizen. As listed in Figure 2, elements included the Town Hall as a source of identity, pride, and memory for Christchurch, as a space and an enabler of the arts, as a civic space (Christchurch's 'public living room') and the sense of ownership Christchurch citizens felt (or should feel) for the building. The context of the earthquakes was significant, as many suggested that a commitment to restore the Town Hall would be a symbolic boost for the rebuild, and psychologically benefit the Christchurch community while its demolition would be a detriment. In her 2015 deputation Halliday drew on the 'All Right' survey to

\footnotetext{
${ }^{114}$ Stewart Brand, How Buildings Learn: What Happens after They're Built, Rev. ed.. (London: Phoenix Illustrated, 1997), 92.
} 
demonstrate the decreased wellbeing associated with the loss of Christchurch's sense of place, and to argue that the Town Hall was especially needed in this context.

The Town Hall's utility was the quality most prominently used to demonstrate its value to the community. The use of Town Hall for significant community events and life events was used to state that many Christchurch citizens would have memories of and associations with the Town Hall. They act as arguments that the Town Hall, and more specifically the activities that happened in that space, directly contribute to Christchurch identity (for certain classes of Cantabrians) and the experience of being a Christchurch citizen. The deputations especially discussed the community value as being tied to its extensive use for significant social events: prize-givings, graduations, concerts, citizenship ceremonies and so on. In his 2015 deputation Lochhead said:

I think it's important to remember that the Town Hall is both a performance venue and our most important civic space. ... In other contexts I've described the Town Hall as our public living room, the space where we come together to mark the significant moments in our collective life as a city.

Deputations by non-KOTH advocates particularly framed their advocacy through the music community's depravation of adequacy facilities. In submissions music professionals and enthusiasts also used the notion of the Town Hall as a venue in a different sense, in that it was a facility where the acoustics and architecture were enablers of great performances and working experiences. These deputations also reiterated the need to improve the backstage facilities and the James Hay acoustics.

\subsubsection{Personal connection}

Articulation of a personal connection or personal significance of the Town Hall was a consistent (but not universal) theme. These were most prominent in the support letters. Broadly, these connections were professional (a designer or a musician involved with the building), as a visitor (whose experience of the Town Hall informed their experience of Christchurch) or as a Christchurch native, for whom the Town Hall might have ongoing associations of home. These types of statements often, but not always explicitly, carried qualified emotions the writer associated with the Town Hall, for example pride or delight. While these were all closely associated with experiences that could be general, the personal element gave the expressions a different quality. 


\subsubsection{Organ}

Finally, the organ itself was a key point of value for many musicians. The organ was the focus of submissions by Martin Setchell and the Friends of the Town Hall Organ Trust, and many of the supporters from the music community. They stressed how intrinsic the organ is to the auditorium, as the organ was designed for that space and would be unlikely to perform as well in any other.

\subsection{2 'Communities' of the Town Hall}

The literature review discussed the concept of 'communities of interest', and notions of use and profession. Bringing this theory to bear on the values expressed in advocacy reveals nuances of the Town Hall's 'communities'.

Value expressions were closely tied to advocates' professions. This was evident in both the value which advocates chose to articulate and the way they were articulated. This suggests that 'communities of profession' is one way to understand the communities of the Town Hall. However, this analysis is heavily influenced by KOTH's focus on architects and musicians to support the advocacy, which was clearly reflected in the submissions. Advocates identified their own professions and connections to the Town Hall. Thus, this analysis of connections between advocacy 'communities' and expressed values uses self-identified communities to consider the value categories, rather than drawing communities from the nature of the expressed values.

Geographic origin was a notable feature of each support letter. In the initial stage of this analysis, this influenced the impact of the value expressions. For example, letters from international experts reinforced that the Town Hall had international influence, and letters from local reinforced its significance to Christchurch citizens. However, there was not a clear divide between geographic origin and the values expressed. Many overseas supporters included a comment on a personal connection with or experience of the Town Hall, as visitors or natives. One example was Paul Walker, an architecture professor in Australia who grew up in Christchurch. He wrote a support letter 'as a native of Christchurch' and later he discussed the significance of his personal memories of the Town Hall, saying 'I was very grateful to have the opportunity to contribute a letter [short chuckle, indicting how little effort this was] to help save it...' (Halliday and Walker, 2018). Walker's comments demonstrate certain dangers of assuming that the communities of place are those with immediate physical 
proximity to the place. Again, these communities were constructed by KOTH's strategy, as KOTH reached out to prominent individuals overseas and around the country.

\subsubsection{Intertwining values}

Many of the value expressions were inextricably intertwined. In particular the architectural value had different significances, as discussed above. The 2015 deputations especially intertwined arguments about the importance of restoring both the architecture and its utility for example, how the ambience and acoustics of the auditorium, or the multiple diverse spaces, enabled its extensive use. Historic and social value were also intertwined, especially in deputations. In the 2015 deputations, Lochhead and Halliday both linked the significant financial contribution that the Christchurch public raised for the construction to ongoing community significance. Generally, different people (or professions) gave different viewpoints. However, some supporters wrote about multiple slants on the same value. This shows professionals, such as architects are aware of the multiple facets of their work. It also iterates that there are intersections between all value categories, and between communities of interest.

\subsubsection{Summary}

Analysis of the values articulated around the Town Hall in the advocacy representations reveal close integration of expert heritage values and social values. In this situation, those expressing values were both experts in 'formal' heritage values, and members of the community of place, which produced value arguments that combined professional and personal perceptive. There were a variety of intersecting values, given slightly different emphasis depending on who was writing. The values expressions do need to be read in context of a focused advocacy campaign. Values expression may not represent the full range or distribution of values held regarding the Town Hall, or be representative of the communities of use, profession, and location that produced them.

The advocates' arguments were designed to be effective. This would likely have influenced the emphasis of different value expressions, and withheld certain qualifications.

Although the values expressed in the support letters and the deputations have been analysed together, there were dissimilarities, particularly in emphasis. These show the impacts of different advocacy processes represented in this case study. 


\subsection{General Submissions on the Town Hall, 2012-2015}

The Town Hall was explicitly mentioned in approximately $2 \%$ of submissions to the draft CCC plans in 2012 and 2015 (of approximately 3000). The Town Hall was not a major issue to submitters and statements show mixed opinions about its future. Approximately $25 \%$ of explicit submitters supported full restoration (see Table 3 and Table 4 in Appendix 8.4). There was little expression of value ( $~ 50 \%$ of Town Hall submissions in $2012, \sim 30 \%$ in 2015) and expressions largely mentioned aesthetics and functionality without depth of meaning. Submissions reflected commentary at the time. For example, most 2012 submissions were based on the information in the draft plan. Council finances issues, such as rates and asset sales, dominated in 2015.

Consultation on the Three-Year Plan 2013-16 received only seven submissions on the Town Hall. Three of these indicated support for the Town Hall without value statements. Three others made clear arguments of support for the Town Hall; these were by KOTH, IConIC, and an associated individual who vocally supported the Town Hall online - they expressed architectural and personal values. The Canterbury Employers Chamber of Commerce was the only negative submission, which expressed concern about the cost of restoring the Town Hall, and about the Town Hall being isolated from a future PAP. This difference from 2012 and 2015 shows that organisations with strong feelings about the Town Hall used the plan submission process as a platform to continue to put their views forward.

General submissions are highly unlikely to be truly representative of the general population. Submissions are discussed as a counter point to the advocacy process, as they demonstrate that there was not universal support for the Town Hall and that individuals disliked it (negative comments included dislike for brutalism architecture and its functionality). The general public had a range of views with a range of strengths both for and against the existing Town Hall. They also demonstrate how open consultation processes have little ability to draw out the heritage values held by citizens, as the literature review suggested. ${ }^{115}$

\subsection{Council discourse and input of advocacy}

As stated, video recordings of Council meetings only exist after late 2013. Therefore, the 2015 Council debate and vote is the only one of the three votes which can be analysed in

\footnotetext{
115 Jones, 'Wrestling with the Social Value of Heritage: Problems, Dilemmas and Opportunities'; Chris Johnston, 'Seeing through Others' Eyes: Understanding the Aesthetics and Meanings of Place', Historic Environment 28, no. 1 (2016): 26-39.
} 
detail. Minutes exist for the other committee and council meetings, as well as minor comments in news articles, but these are not detailed enough to attempted to unpick the rhetoric and value expressions.

In discussing the first two council decisions, Halliday and Lochhead felt that the Bob Parker council was highly respectful to Warren and Mahoney, and more persuaded by the heritage arguments put to them. News articles support this view, particularly as there was no business case at that stage. Lochhead felt that these first two, unanimous votes created momentum and precedent for each subsequent vote, and that any vote against full restoration would have been hard to turn around.

The statements by councillors in the final debate contained a mixture of economic, social value, and civic value rhetoric. It is important to contextualise this debate, as it occurred the day after six passionate and articulate deputations in favour of retaining. Many advocates observed the council debate. The councillors would have been aware that they were effectively making statements to the media. Ultimately, I conclude that the economic arguments were the primary enabler the decision. However, social values (personal and community values) were used in the rhetoric of the decision. In this way, the decision was framed as the restoration of a community venue and a civic icon, and (to certain extent) pushback against CERA control from the previous three years.

Almost every councillor mentioned finances as a key reason to fully restore the Town Hall, and for others it seemed to be an implicit point that they didn't wish to labour over. Mayor Dalziel pushed the point home when she opened her closing remarks by saying 'I want to begin by rejecting the notion that this is an emotional decision attached to the connection with the building...' She came back to the financial points several times throughout the deputations and debate. Halliday, Bennett, and Lochhead all stated they felt that the financial situation was the deciding factor in the decision.

That said, councillors spoke at length about the social and community attachment to the building, including their own experiences. These were often quite closely intertwined with their financial arguments. Even some of those who said that the decision was entirely about the finances chose to reflect on their personal memories and the community significance of the Town Hall, including Mayor Dalziel. According to Lochhead, this was also a prominent feature of debates under the previous council, and perhaps had even more of an impact on the decision. 
A greater point was the Town Hall's significance as a civic space, particularly given its location in the central city. This was a key assessment criterion for the staff report. Many of the councillors made statements about how they saw the Town Hall contributing to the future and community of Christchurch, as it had in the past.

There was also, in my estimation, a certain amount of tension evident between CCC and CERA in the debate. Dalziel's comments throughout all point to the context of continued central government control in Christchurch and planning practices that were having a poor impact on the development of the city. Discussion about the Town Hall was often made with reference to the Cost Sharing agreement and the CCRP, with emphasis being placed on the CCRP wording that the PAP was to provide a concert hall 'if the Town Hall was unrepairable.' Several councillors made pointed references to Minister Brownlee and CERA, and put the Town Hall forward as an opportunity for CCC to make its own decisions and lead on its own projects.

Bennett suggested that this may have had an element of performance, despite having written about CCC/CERA dynamics regarding the Town Hall. ${ }^{116}$ However, Lochhead felt the Council decision was a genuine assertion of CCC's right to make its own decisions, and thought it required bravery in the face of the 'brow-beating' CERA had delivered to CCC. The situation changed somewhat between earlier votes and 2015. By 2015 the Town Hall was less tied up with CERA's plans, as the PAP was CCC's responsibility through the Cost Sharing Agreement, and CERA had removed the land designation.

The issue of heritage listings, both by HNZPT and CCC came up a number of times in two regards: one, whether heritage listing would hinder the project, and two, that the Town Hall should have been on the HNZPT List. Discourse regarding the first point demonstrated low understanding of the impact of the different listings. The heritage listing agency's (CCC's) protection mechanism had been fulfilled by the 2015 debate, as the resource consent for the proposed restoration had recently been granted. Comments on the second point suggested that the Town Hall and Christchurch was missing out on recognition by omission from the List. Mayor Dalziel stated that the Town Hall should have been HNZPT listed; she felt that, had it been listed, the Council would have had someone else in their corner supporting their decision.

${ }^{116}$ Bennett, 'This Isn't about the Christchurch Town Hall'. 
The councillors' rhetoric suggests that the advocacy and KOTH support letters had an impact on the council decision. General plan submissions seem to have had very little impact, if any. In every council decision the overwhelming support for the Town Hall in submissions was noted, although the general plan submissions show a preference for demolishing the Town Hall. This was likely because general submissions were less expressive, and were analysed and summarised by staff. In contrast, Town Hall advocates made representations directly to councillors and were highly expressive. Their chief impact was likely in their consistency, as there was little comment on the contents of the letters. In the 2015 debate several councillors reiterated arguments made in deputations. Another example is that $\mathrm{Cr}$. Turner commented that he 'wasn't previously aware of' many of the arguments for the Town Hall before he deputations.

Advocates' expertise (evidenced by academic qualifications) and social standing undoubtedly played a part in the impact. The power of personal deputations was most evident in the deference shown to Warren and Mahoney. Warren's civic benevolence was referenced at different times, including the gift of his home, Ohinetahi, to the people of New Zealand in 2012 and his role in saving the Lady Isaac Theatre in 2015. Halliday and Lochhead felt that having Warren, Mahoney and Marshall present had a significant impact. This shows the potential impact of having a well-respected designer present to talk to the history, significance, and flaws of their own work. However, the impact of these personal deputations does highlight the inherent prejudices of the consultation/submission process and the impact of positions of social privilege.

In summary, the 2015 Town Hall decision stood squarely on the economic and insurance situation. It also had a clear use which was directly relevant to the goals of the city. After that, the heritage value was window-dressing to a certain extent. However, the submissions and deputations did have an effect, in terms of how the council could frame their decision, but also apparently in their direct influence on Councillors (esp. in volume and consistency). Lochhead especially felt they were most effective under the Bob Parker council, which was significant in that it would have been extremely hard to reverse a decision to demolish. The 2015 debate did show evidence of CCC/CERA tension, but it was not a central part of the rhetoric. 


\subsection{Impact of the Town Hall debates}

The debates about the Town Hall resulted in an increase of public discourse and information about the Town Hall. Bennett discussed that he felt that Town Hall was one of the few issues that created a genuine public debate, and in doing so 'it revealed that there was participation in the recovery by lots of different parties, but it was rarely public.'

An exhibition about the construction of the Town Hall was produced by the University of Canterbury in September 2015. ${ }^{117}$ The advocacy expanded the value of the Town Hall to the campaigners themselves - Lochhead discussed how he learnt more about its technical acoustic significance, particularly in talking with Sir Harold Marshall. Lochhead is currently editing a book on the Town Hall's history from origin to restoration.

CCC has continued to use the Town Hall restoration in public relations material. They have published a number of 'progress' videos and created media opportunities. They continue call it Christchurch's public living room (see Figure 3, and Christchurch City Council 2016)

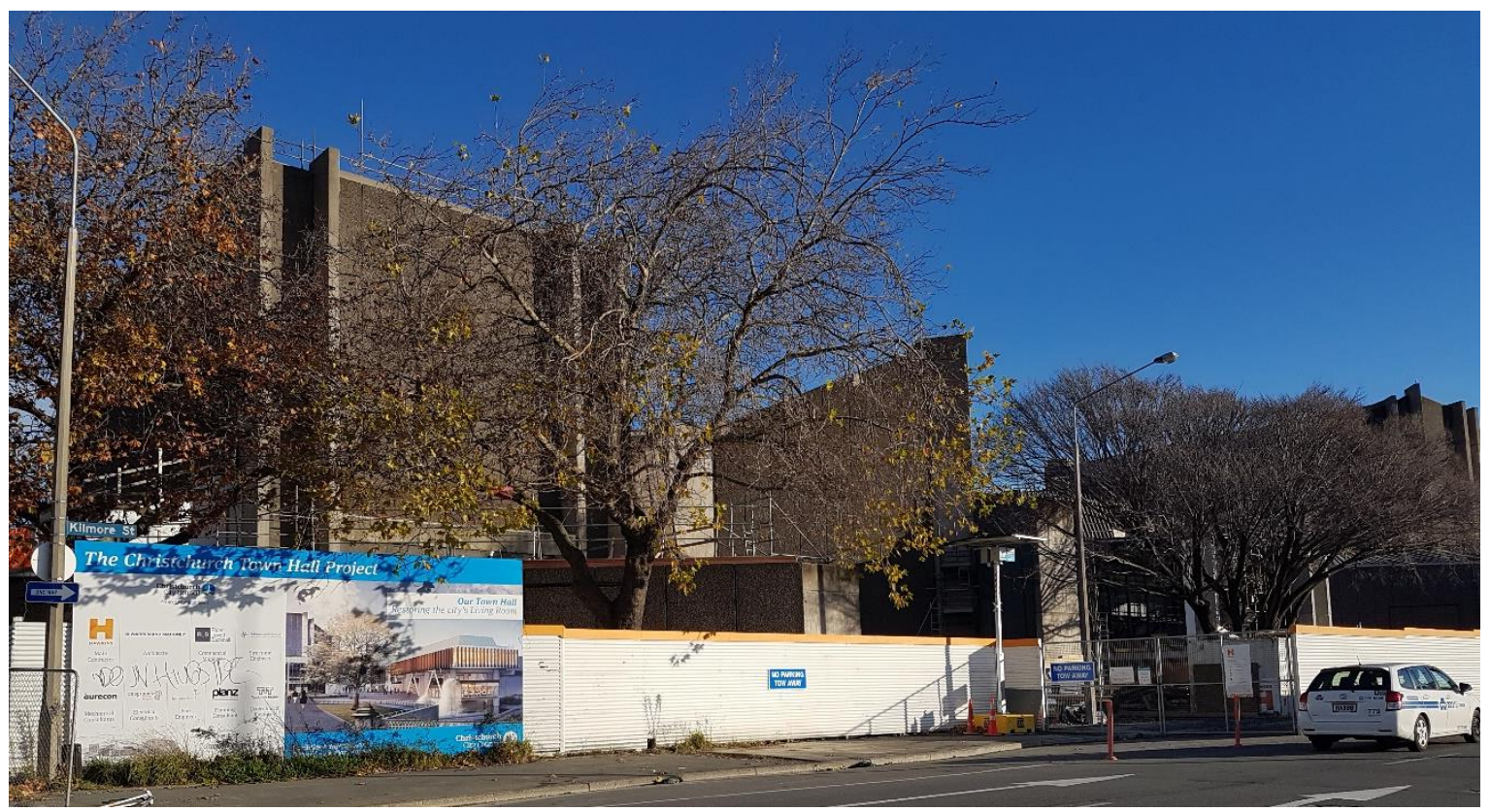

Figure 3: The Christchurch Town Hall from Kilmore St, May 2018. The slogan on the billboard reads 'Our Town Hall: Restoring the city's Living Room.' (Photo: Mary Ann Halliday).

The Christchurch Town Hall and its interior remain listed on the CCC district plan as highly significant, and part of the Victoria Square area. The assessment of cultural and spiritual significance uses the efforts to conserve it as evidence that the building is 'valued by the

117 Architecture Now, 'Historic Warren and Mahoney Drawings: Christchurch Town Hall', Architecture Now, September 2015, /calendar/exhibitions/historic-warren-and-mahoney-drawings-christchurch-town-hall/. 
people of Christchurch and Canterbury. ${ }^{, 18}$ It does not discuss the specific values that were expressed, or the nuances of the communities of people who value the building. It remains absent from the HNZPT list.

\section{$5.8 \quad$ Summary}

This section has covered the narrative of the Town Hall debate, covering the three Council votes and associated events that lead to its eventual restoration. This contextualised the advocacy in support of full restoration of the Town Hall, and connected the Town Hall with the wider politics of post-quake Christchurch. The advocacy strategy of KOTH, as described by the advocates, was laid out in order to consider the production of the value expressions, and potential elements of 'participatory practice. The core of this chapter was the analysis of the values expressed in deputations and support letters put to council. The analysis organised the expressed values in categories aligned with normative heritage frameworks, including architectural value and social value, but also with values which might sit outside normative frameworks, such as personal connections and the restoration value and replacement uncertainty in the context of the post-quake environment. The analysis considered 'communities' could be seen in the value expressions, which being mindful that the expressions were constructed by the advocacy process and KOTH's outreach for support. The section discussed the influences on the Council rhetoric around the decision to restore. It discussed that the positive financial report was a major influence, the civic value (and personal connections) significantly featured. Finally, a few examples of the continuing impact of the Town Hall debates were pressed.

${ }^{118}$ Christchurch City Council, 'Victoria Square Area Heritage Assessment,' 33, https://districtplan.ccc.govt.nz/Images/DistrictPlanImages/Statement\%20of\%20Significance/Central\%20City/HI D\%20527.pdf 


\section{Conclusion}

This research built on international literature on participatory approaches to social value. It chose to look at a specific case of collective action as participation. The key research questions were:

1) What heritage values were expressed through collective action?

i. Particularly, what social values were expressed?

2) What was the relationship of those values to the participation processes, communities, and wider situation that produced them?

3) What was the impact of the expressed values on institutional rhetoric and decisions?

The questions were applied to the advocacy for the Christchurch Town Hall which occurred from 2012-15. Understanding the context of post-quake Christchurch was critical to investigating this case. The Town Hall debates were closely connected with wider political events. The Town Hall advocacy also had close connections with other heritage advocacy and urban activism happening at the time. It offered the potential to explore new modes of grassroots practice.

The analysis of the values expressed by advocacy for the Town Hall found that they adhered to 'formal' heritage values in some ways, in terms of architectural and social value, but also other considerations, particularly in relation to the specific context of the quakes. While financial considerations were an important factor in the final council decision, the advocacy had an impact through the first two debates, and shaped the rhetoric in the final debate.

The Town Hall advocacy was certainly motivated by and expressed personal and social meanings. All the core advocates had personal connections with the Town Hall and it held memories for them personally. The support letters also articulated personal meanings. These personal meanings originated in and were supported by expert knowledge expressed in formal values, especially architecture and musical performance. The advocacy articulated the social value of the Town Hall based on its function as a civic venue, which created significant memories in the personal and community lives of Christchurch citizens. This discourse shows that, at least in the case of architectural heritage like the Town Hall, 'expert' values associated with the AHD can in many ways be intertwined with other ideas of social value and memory. The advocacy format did not require separation of formal and informal values as value frameworks do. It indicates that theories of performance, experience, emotion, and 
personal response are acknowledged in the professions that have historically dominated heritage value frameworks.

Separate 'communities' proved to be one way to frame the different values expressed in the advocacy submissions. However, these communities were non-homogeneous as seen in the high intersection of technical/professional and personal meanings. It shows that collective community value is often framed though multiple forms of expertise and experience 'expertise' understood in multiple senses of technical expertise and expertise in being/experiencing. This analysis of connections between advocacy 'communities' and expressed values used self-identified communities to consider the value categories, rather than drawing communities from the nature of the expressed values. This may have implications for practices if consultation practices were being used. However, it is notable that most of the Town Hall advocates chose to state their profession and connection to the Town Hall. In doing so, they used it as a credential for their advocacy, both in terms of professional expertise and experience-of-place expertise. They implicitly identified how the Town Hall connected with their membership of a particular community, whether a community of profession, interest, or use. This implicit analysis especially underlines the Town Hall's social value to a number of communities.

The Town Hall advocacy was not a participatory practice unto itself, such as an institution would conduct. A selective strategy was used because the KOTH advocates wanted to hone a clear, non-conflicting argument and because they wanted to marshal their resources in light of other projects they had underway. However, the advocacy itself was participation in the council process of deciding the future of the Town Hall, enabled by public ownership through the council. The public input influenced the first two council votes, it demonstrated significance and prestigious support for the Town Hall, and shaped influenced ongoing rhetoric.

The Town Hall debates had political significance in post-quake Christchurch, when the Council and citizens had less say in the (re)creation of Christchurch than they would have were regular mechanisms for representation and push-back available. As such, the Town Hall was sometimes constructed as a site of push-back against CERA control. It was a site for the negotiation and competition of wider issues, and illustrates that heritage issues can and do act as a proxy for broader social and political issues. It was a site of interaction of heritage and democracy. 
The advocacy itself was a heritage-making process because it assembled, disseminated and precipitated discourse about the Town Hall as a heritage place, therefore (re)creating meaning. This can be seen in the ongoing use of the advocacy rhetoric in CCC publicity, broader public engagement with the Town Hall debates, and in Lochhead's ongoing engagement with the Town Hall with his forthcoming book. This reflects some of the heritage-making aspects of participatory projects discussed in the literature, particularly by Siân Jones and Svava Riesto and Anne Tietjen. ${ }^{119}$

In addition to the key research findings, this research presented a number of lessons and confounded some of my original conceptions about heritage management. These offer a number of tangential opportunities for future research.

Regarding general assumptions about heritage management, this research changed my understanding that heritage agencies advocate on behalf of communities. The Town Hall advocacy shows that communities have a powerful role in directly influencing heritage decisions, one that heritage agencies may not be able to play. My understanding of heritage 'protection' (by HNZPT and the RMA) has been reframed as 'mechanisms of push-back,' which have to be activated. However, there are democratic issues with assuming that communities can and will serve as heritage protectors through advocacy. It favours communities who have the skills and resources to do so (such as the highly educated, respected advocates for the Town Hall). This is particularly problematic for the heritage of minority or marginalised cultures. How can you successfully explain the value of a place to a council or heritage agency if you inhabit a completely different worldview? Social value and participatory assessment is often used for indigenous heritage for this reason. The Town Hall case does not help solve these issues of inclusion.

Post-quake Christchurch also showed how tenuous New Zealand heritage mechanisms are. Research into the protections for heritage in New Zealand disaster circumstances may be warranted (although anecdotally I understand this has become a research and policy priority). I am not in a position to state whether the Town Hall should have been on the HNZPT List. However, future research could consider why it is not listed, and resulting implications for the credibility of the HNZPT list and the effectiveness of HNZPT's listing processes. Furthermore, the extent to which non-heritage factors came to bear on the Town Hall

\footnotetext{
${ }^{119}$ Jones, 'Wrestling with the Social Value of Heritage: Problems, Dilemmas and Opportunities'; Riesto and Tietjen, 'Doing Heritage Together'.
} 
decision offers scope to consider pro-heritage incentives beyond regulation, such as insurance coverage specifically attached to heritage features.

This research confounded the idea of a strict dichotomy between formal and non-formal heritage. Discourses and perspectives on heritage have a nuanced interaction - AHDs and non-expert values may not be completely separate. For one thing, AHDs have the power to impact other forms of discourse, making it hard to disentangle cultural impacts. There is further complexity because (Western) AHD discourses can reflect everyday processes which make heritage precious, significant and important. This is primarily true where formalised heritage paradigms and heritage places/objects come from the same culture, which is to say Western architectural and historical traditions. The Town Hall clearly fits into this tradition. Furthermore, the professions underpinning institutionalised heritage (including architecture, history, and archaeology) are themselves expanding their understandings of their fields and of people-place relationships. For example, AHDs have been criticised for focusing on 'architectural value' at the expense of phenomenology including affect, performance, and meaning-making. However, architectural theory and practice has itself incorporated these ideas. The intertwining of values in the Town Hall advocacy suggests that heritage theory discussions of 'architectural value' may not align with professional architectural discussions of 'architectural value'. Different research may also like to consider this point.

In seeking out a case study, more concerted use of personal and professional networks would be beneficial. More flexibility around the research focus and clearer communication around the terminology being used would also be beneficial. This includes realising professionals' terminology may differs from literature, and accordingly having more open-ended discussions about respective meanings. The examples that were rejected for this research HNZPT's Rangitikei-Ruapehu project, Omaio ki Tua, and CCC's 'Future of Heritage' engagement and strategy - still hold the potential to create insights into current and future practice. Additionally, this research approach of considering consultation processes could be applied to other situations. For example, HNZPT's listing process allows for submission letters from the general public. Analysing these could be a way to consider who is, and who is not, being represented by HNZPT's process, and how their values are being put forward. Another approach could be a survey of institutional attitudes and approaches to community engagement with built heritage in New Zealand. 
The case-study of post-quake Christchurch and the Town Hall had some limitations for studying participatory practice and social value. The Town Hall's role as one of Christchurch's foremost performance and events spaces meant that its social value would have been easily interpreted by formal assessments. Frameworks of participation, social value, and democracy were not wholly appropriate to apply to post-earthquake Christchurch and particularly the Town Hall advocacy.

The literature review did not engage with two central aspects of the case study, which were the role of and reactions to heritage after disaster, and heritage advocacy. This meant that the analysis has not contextualised the case-study within its key themes, and limited the overall analysis.

The analysis intentionally focused on the actions and perspective of a few key individuals. This was appropriate for the scope and focus of the research. However, it means that many heritage advocates and urban activists have not been fully considered. This is not a comprehensive account of the Town Hall advocacy. Non-KOTH advocates could also be more closely considered, such as Voice of Music, as could have the heritage advocacy that I only talk about briefly (particularly through deeper investigation of IConIC and Historic Places Canterbury).

Much of the literature review was concerned with social value in a normal situation. This dissertation took the opposite approach by looking at heritage advocacy. Heritage advocacy responds to a specific threat, which generates a heightened sense of value. This makes heritage campaigns a poor measure of the 'normal' depth of feeling for the place. However, campaigns are often used to evidence the social value of a place precisely because they are a rare moment when the public actively articulates the place's value. I was motivated to investigate social value though a historic campaign because data was readily available, whereas trying to gather it in a 'peace time' situation is problematic. This example also does not address the use of participation to move from community to places - here, the Town Hall was a pre-identified place and the research then considered how different people responded to it through specific processes.

It is unclear how useful the notion of 'collective action as participation' might be in heritage practice. Heritage advocacy has significant draw-backs in terms of representation and being comparable with formal formats. They are unpredictable, reactionary, and take a high toll on activists. Nevertheless, heritage assessment can already use heritage advocacy to some extent, 
to demonstrate a heritage place's significance to the community. This analysis has shown how the nuances of such advocacy can be dissected, both in terms of the values associated with the place, and nature of the communities who hold that value. There may be value for heritage institutions to acknowledge these nuances. This may allow them to articulate the cultural impacts and significance of heritage advocacy campaigns, and consider new approaches to their own practice. In the case of the CCC Town Hall listing, this might involve acknowledging KOTH specifically, and the communities of local, national, and international architects and musicians who contributed, rather than conglomerating the advocacy to say the Town Hall is 'valued by the people of Christchurch and Canterbury.'

That said, this has been an intensive research and analysis process which has required iteratively returning to the data, and further insights may have been available with greater time resources. This research has been able to draw on pre-existing data, rather than produce it through participatory process. This reinforces the issue with community-focused social value projects, as highlighted in the literature. While the techniques of practitioners such as Chris Johnston may have significant advantages over other approaches, they may still be beyond many over-stretched institutions. Institutions will have to continue to consider the costs and benefits of these processes in light of their own resources and priorities.

Ultimately, the use of engaged participation and meaning-rich community research to articulate and activate heritage values in different context remains an open investigation field. Such methods might assist institutions to confront their privilege and authorised dominance, diversify their notions of heritage values, and to better serve the communities to whom they have a legal and moral obligation. Some communities can and will do this themselves. That does not preclude the possibility of better practices within institutions. 


\section{Bibliography}

Amore, Alberto. 'The Governance of Built Heritage in the Post-Earthquake Christchurch CBD'. In Business and Post-Disaster Management: Business, Organisational and Consumer Resilience and the Christchurch Earthquakes, edited by Colin Michael Hall, Sanna Malinen, Rob Vosslamber, and Russell Wordsworth. London: Routledge, 2016.

Architecture Now. 'Historic Warren and Mahoney Drawings: Christchurch Town Hall'. Architecture Now, September 2015. /calendar/exhibitions/historic-warren-andmahoney-drawings-christchurch-town-hall/.

Arnold, Naomi. 'On the Edge'. Heritage New Zealand Magazine, no. 148 (Autumn 2018): $36-41$.

Arnstein, Sherry R. 'A Ladder of Citizen Participation'. Journal of the American Planning Association 35, no. 4 (1969): 216-24. https://doi.org/10.1080/01944366908977225.

Bennett, Barnaby. 'A Guide to Christchurch Rebuild for the Rest of NZ'. Project Freerange (blog), 15 September 2014. http://www.projectfreerange.com/a-guide-to-christchurchrebuild-for-the-rest-of-nz/.

. 'Keep Our Town Hall Again'. Project Freerange (blog), 27 August 2013. http://www.projectfreerange.com/keep-our-town-hall-again/.

. 'The Politicisation of CERA and the Planning of New Christchurch'. Project Freerange (blog), 6 May 2014. http://www.projectfreerange.com/the-politicisationof-cera-and-the-planning-new-christchurch/.

—. 'This Isn't about the Christchurch Town Hall'. Project Freerange (blog), 21 June 2013. http://www.projectfreerange.com/this-isnt-about-the-christchurch-town-hall/.

Bennett, Barnaby, Eugenio Boidi, and Irene Boles, eds. Christchurch: The Transitional City, Pt. IV. Wellington, NZ: Freerange Press, 2012.

Bennett, Barnaby, James Dann, Emma Johnson, and Ryan Reynolds. 'Introduction'. In Once in a Lifetime: City-Building after Disaster in Christchurch, edited by Barnaby Bennett, James Dann, Emma Johnson, and Ryan Reynolds, 18-27. Christchurch, NZ: Freerange Press, 2014.

Blake, Louise. 'Rescuing the Regent Theatre'. Provenance: The Journal of Public Record Office Victoria, no. 11 (2012). https://www.prov.vic.gov.au/index.php/explorecollection/provenance-journal/provenance-2005/rescuing-regent-theatre. 
Brand, Stewart. How Buildings Learn: What Happens after They're Built. Rev. ed.. London: Phoenix Illustrated, 1997.

Brittenden, W. J. A. (William James Arnold). A Dream Come True: The Christchurch Town Hall. Christchurch, N.Z.: Christchurch Town Hall Committee, 1972.

Cairns, Lois. 'Christchurch City Council Bungled District Plan Review - Report'. The Press, 18 November 2015. https://www.stuff.co.nz/the-press/news/74073447/christchurchcity-council-bungled-district-plan-review--report.

Canterbury Earthquake Recovery Act (2011). http://www.legislation.govt.nz/act/public/2011/0012/latest/DLM3653522.html.

Carville, Olivia, and Keith Lynch. 'Protesters Breach Cordon'. The Press. 22 March 2011. http://www.stuff.co.nz/the-press/news/christchurch-earthquake2011/4793408/Protesters-breach-cordon.

Chitty, Gill, ed. Heritage, Conservation and Communities: Engagement, Participation and Capacity Building. Abingdon, Oxon: Routledge, 2017.

—. 'Introduction: Engaging Conservation - Practising Heritage Conservation in Communities'. In Heritage, Conservation and Communities: Engagement, Participation and Capacity Building, edited by Gill Chitty, 1-14. Abingdon, Oxon: Routledge, 2017.

Christchurch Central Development Unit. 'Christchurch Central Recovery Plan'. Christchurch Central Development Unit, 30 July 2012.

Christchurch City Council. Christchurch Town Hall Restoration Progress - YouTube. Chrsitchurch, 2016. https://www.youtube.com/watch?v=sE5QCbEEpBI. . 'Council and Crown Earthquake Cost Sharing': www.ccc.govt.nz. Accessed 9 May 2018. https://www.ccc.govt.nz/the-council/plans-strategies-policies-andbylaws/strategies/christchurch-city-council-and-crown-earthquake-cost-sharing. . Media Tour of the Christchurch Town Hall - 28 August 2013, 2013. https://www.youtube.com/watch?v=_NPE-oPs-Y8.

. 'Minutes of a Meeting of the Christchurch City Council Held at 9:30am on Thursday 22 November 2012'. Christchurch: Christchurch City Council, 22 November 2012. http://resources.ccc.govt.nz/files/TheCouncil/meetingsminutes/agendas/2012/Novemb er/Council_22Nov2012ConfirmedMinutes.pdf.

- 'Scheduled Interior Heritage Fabric, Heritage Item Number 311: Christchurch Town Hall - 100 Kilmore Street, Christchurch'. Christchurch City Council, n.d. 
https://districtplan.ccc.govt.nz/Images/DistrictPlanImages/Heritage\%20Fabric/HID\% 20311\%20-\%20Christchurch\%20Town\%20Hall.PDF.

- 'Smart Choices 2015-2025 Christchurch City Consultation Document'.

Christchurch, NZ: Christchurch City Council, 10 March 2015.

http://www.ccc.govt.nz/assets/Documents/The-Council/Plans-Strategies-Policies-

Bylaws/Plans/Long-Term-Plan/draft2015/CCCLTPConsultationSummary201525.pdf.

-. 'The Future of Heritage'. Chrsitchurch City Council Website. Accessed 4 June 2018.

https://ccc.govt.nz/the-council/consultations-and-submissions/haveyoursay/show/15.

- 'Three Year Plan 2013-16'. Christchurch City Council Website. Accessed 24 May

2018. https://www.ccc.govt.nz/the-council/plans-strategies-policies-and-

bylaws/plans/long-term-plan-and-annual-plans/older-plans/three-year-plan-2013-16/.

' 'Victoria Square Area Heritage Assessment'. Accessed 31 May 2018.

https://districtplan.ccc.govt.nz/Images/DistrictPlanImages/Statement\%20of\%20Signif icance/Central\%20City/HID\%20527.pdf

Clark, Kate. 'Values in Cultural Resource Management'. In Heritage Values in

Contemporary Society, edited by George S Smith, Phyllis Mauch Messenger, and

Hilary A Soderland, 89-100. Walnut Creek, Calif.: Left Coast Press, 2010.

Cleary, Gerard. 'Adopting and Implementing a Legislative Framework for Recovery'. In

Once in a Lifetime: City-Building after Disaster in Christchurch, edited by Barnaby

Bennett, James Dann, Emma Johnson, and Ryan Reynolds, 136-44. Christchurch,

NZ: Freerange Press, 2014.

Clifford, Sue. 'Local Distinctiveness: Everyday Places and How to Find Them'. In Local

Heritage, Global Context: Cultural Perspectives on Sense of Place, edited by John

Schofield and Rosy Szymanski, 1-12. Farnham, Surrey: Ashgate, 2011.

Cornwall, Andrea. 'Preface'. In The Participation Reader, edited by Andrea Cornwall, xiixx. London: Zed Books, 2011.

'Council and Crown Earthquake Cost Sharing'. Christchurch City Council Website. Accessed

20 April 2018. https://www.ccc.govt.nz/the-council/plans-strategies-policies-and-

bylaws/strategies/christchurch-city-council-and-crown-earthquake-cost-sharing/.

Council of Europe. Council of Europe Framework Convention on the Value of Cultural

Heritage for Society (2005). https://rm.coe.int/1680083746.

Cox, Elizabeth. A Friend Indeed: The Saving of Old St Paul's. Wellington, NZ: The Friends of Old St Pauls, 2018. 
Crampton, Eric, and Linda Meade. 'Deadly Heritage'. Wellington, NZ: The New Zealand Initiative; Deloitte New Zealand, May 2016. https://nzinitiative.org.nz/reports-andmedia/reports/deadly-heritage/.

Crooke, Elizabeth. 'The Politics of Community Heritage: Motivations, Authority and Control'. In Heritage and Community Engagement: Collaboration or Contestation?, edited by Emma Waterton and Steve Watson. Abingdon: Routledge, 2013.

Denscombe, Martyn. The Good Research Guide: For Small-Scale Social Research Projects. Fifth edition. Maidenhead, UK: Open University Press, 2014.

English Heritage. Conservation Basics. Edited by Iain McCaig and Graham Abrey. London: Ashgate, 2013.

\section{—. 'Conservation Principles, Policies and Guidance', 2008.}

Gibson, Lisanne. 'Cultural Landscapes and Identity'. In Valuing Historic Environments, edited by Lisanne Gibson and John Pendlebury. New York: Routledge, 2009.

Gordon, Alex. 'Another Old Lady to Be Knocked Down: Heritage Discourse and the Protest to Save the Missions to Seamen Building, 1986'. Unpublished Master's Dissertation, Victoria University of Wellington, 2018.

Halliday, Jessica. 'Losing Our Collective Memory: The Importance of Preserving Heritage Architecture'. In Once in a Lifetime: City-Building after Disaster in Christchurch, edited by Barnaby Bennett, James Dann, Emma Johnson, and Ryan Reynolds, 21016. Christchurch, NZ: Freerange Press, 2014.

Halliday, Jessica, and Paul Walker. 'Heritage, Activism, Architecture'. presented at the Melbourne Design Week; Parlour, Melbourne, Aus., 21 March 2018.

Harrison, Rodney. “'Counter-Mapping' Heritage, Communities and Places in Australia and the UK'. In Local Heritage, Global Context: Cultural Perspectives on Sense of Place, edited by John Schofield and Rosy Szymanski, 65-78. Farnham, Surrey: Ashgate, 2011.

-. Heritage: Critical Approaches. New York: Routledge, 2013.

Ianniello, Mario, Silvia Iacuzzi, Paolo Fedele, and Luca Brusati. 'Obstacles and Solutions on the Ladder of Citizen Participation: A Systematic Review'. Public Management Review, 2018, 1-26. https://doi.org/10.1080/14719037.2018.1438499.

ICOMOS Australia. The Australia ICOMOS Charter for Places of Cultural Significance (2013). http://australia.icomos.org/wp-content/uploads/The-Burra-Charter-2013Adopted-31.10.2013.pdf. 
International Association for Public Participation Australasia. 'Spectrum'. Accessed 18 May 2018. https://www.iap2.org.au/About-Us/About-IAP2-Australasia-/Spectrum. Johnston, Chris. 'Inhabiting Place: Social Significance in Practice in Australia'. APT Bulletin 45, no. 2/3 (2014): 39-47.

—. 'Seeing through Others' Eyes: Understanding the Aesthetics and Meanings of Place'. Historic Environment 28, no. 1 (2016): 26-39.

—. 'What Is Social Value?' Canberra: Australian Heritage Commission, 1992. Jones, Siân. 'Wrestling with the Social Value of Heritage: Problems, Dilemmas and Opportunities'. Journal of Community Archaeology \& Heritage 4, no. 1 (2017): 1-17. https://doi.org/10.1080/20518196.2016.1193996.

Light, Duncan. 'Heritage and Tourism'. In The Palgrave Handbook of Contemporary Heritage Research, edited by Emma Waterton and Steve Watson, 144-58. London: Palgrave Macmillan UK, 2015. https://doi.org/10.1057/9781137293565.

Lochhead, Ian. 'Let Our Public Living Room Live Again'. The Press. 20 March 2012. Logan, William, Ullrich Kockel, and Máiréad Nic Craith. 'The New Heritage Studies: Origins and Evolution, Problems and Prospects'. In A Companion to Heritage Studies, edited by William Logan, Máiréad Nic Craith, and Ullrich Kockel, 1-25. Chichester, West Sussex, UK; Malden, MA: John Wiley \& Sons, Inc., 2016. http://catalogimages.wiley.com/images/db/jimages/9781118486665.jpg.

Macfie, Rebecca. Report from Christchurch. Edited by Philip Rainer, Pamela Stirling, Geoff Walker, and Inc ebrary. Wellington, NZ: Bridget Williams Books, 2013. -. 'Shock of the View'. In Once in a Lifetime: City-Building after Disaster in Christchurch, edited by Barnaby Bennett, James Dann, Emma Johnson, and Ryan Reynolds, 371-77. Christchurch, NZ: Freerange Press, 2014.

Milligan, Melinda J. 'Buildings as History: The Place of Collective Memory in the Study of Historic Preservation'. Symbolic Interaction 30, no. 1 (2007): 105-23. https://doi.org/10.1525/si.2007.30.1.105.

Onciul, Bryony, Michelle L. Stefano, and Stephanie Hawke, eds. Engaging Heritage, Engaging Communities. Woodbridge, Suffolk: Boydell Press, 2017.

Orange, Hilary. 'Exploring Sense of Place: An Ethnography of the Cornish Mining World Heritage Site'. In Local Heritage, Global Context: Cultural Perspectives on Sense of Place, edited by John Schofield and Rosy Szymanski, 99-118. Farnham, Surrey: Ashgate, 2011. 
Page, Max, and Randall Mason, eds. Giving Preservation a History: Histories of Historic Preservation in the United States. New York: Routledge, 2004.

Parkinson, Arthur, Mark Scott, and Declan Redmond. 'Competing Discourses of Built Heritage: Lay Values in Irish Conservation Planning'. International Journal of Heritage Studies, 2015, 1-13. https://doi.org/10.1080/13527258.2015.1121404.

Pickles, Katie. Christchurch Ruptures. BWB Texts. Wellington, NZ: Bridget Williams Books, 2016.

Pishief, Elizabeth. 'Engaging with Māori and Archaeologists: Heritage Theory and Practice in Āotearoa New Zealand'. In Engaging Heritage, Engaging Communities, edited by Bryony Onciul, Michelle L. Stefano, and Stephanie Hawke, 55-72. Woodbridge, Suffolk: Boydell Press, 2017.

Pocock, Celmara, David Collett, and Linda Baulch. 'Assessing Stories before Sites: Identifying the Tangible from the Intangible'. International Journal of Heritage Studies 21, no. 10 (2015): 962-82. https://doi.org/10.1080/13527258.2015.1040440.

Press staff. 'New City Boss Fit and Ready to Go'. The Press. 31 May 2014. https://www.stuff.co.nz/the-press/news/10106248/New-city-boss-fit-and-ready-to-go. Project Freerange admin. 'Dear New Zealand: This Is on You Too'. Project Freerange (blog), 3 September 2012. http://www.projectfreerange.com/dear-new-zealand-this-ison-you-too/.

Radio New Zealand. 'Christchurch Town Hall Rebuild on Hold'. Radio New Zealand, 9 July 2014. http://www.radionz.co.nz/news/regional/249338/christchurch-town-hallrebuild-on-hold.

Riesto, Svava, and Anne Tietjen. 'Doing Heritage Together - New Heritage Frontiers in Collaborative Planning'. In Heritage, Democracy and the Public: Nordic Approaches, edited by Torgrim Sneve Guttormsen and Grete Swensen, 159-74. Oxon: Routledge, 2016.

Schofield, John, and Rosy Szymanski. 'Sense of Place in a Changing World'. In Local Heritage, Global Context : Cultural Perspectives on Sense of Place, edited by John Schofield and Rosy Szymanski. Farnham, Surrey: Ashgate, 2011.

Smith, Jane. 'Christchurch - a State of Emergency'. In Once in a Lifetime: City-Building after Disaster in Christchurch, edited by Barnaby Bennett, James Dann, Emma Johnson, and Ryan Reynolds, 145-49. Christchurch, NZ: Freerange Press, 2014.

Smith, Laurajane. Uses of Heritage. New York: Routledge, 2006. 
Stewart, Ashleigh, and Joelle Dally. '60 Jobs to Go in Major Christchurch City Council Restructure'. The Press, 27 August 2015. https://www.stuff.co.nz/thepress/news/71504377/60-jobs-to-go-in-major-christchurch-city-council-restructure.

Stockwell, Imogen. 'Making a House a Home: Motivations for Earthquake Strengthening Domestic Homes in Dunedin, an Argument Towards Domestic Heritage'. Victoria University of Wellington, 2016.

Sutton, Roger. 'A Blank Canvass for New Beginnings'. In Once in a Lifetime: City-Building after Disaster in Christchurch, edited by Barnaby Bennett, James Dann, Emma Johnson, and Ryan Reynolds, 52-58. Christchurch, NZ: Freerange Press, 2014.

Te Pūtahi. 'About Us'. Accessed 9 May 2018. http://teputahi.org.nz/about-us/.

Townend, Stephen, and Ken Whittaker. 'Being Accounted For: Qualitative Data Analysis in Assessing 'Place' and 'Value', In Local Heritage, Global Context: Cultural Perspectives on Sense of Place, edited by John Schofield and Rosy Szymanski, 6578. Farnham, Surrey: Ashgate, 2011.

Walter, Nigel. 'From Values to Narrative: A New Foundation for the Conservation of Historic Buildings'. International Journal of Heritage Studies 20, no. 6 (2014): 63450. https://doi.org/10.1080/13527258.2013.828649.

Warren, Miles. Miles Warren: An Autobiography. Christchurch, N.Z.: Canterbury University Press, 2008.

Witcomb, Andrea. Re-Imagining the Museum: Beyond the Mausoleum. Museum Meanings. London; New York: Routledge, 2003. http://ebookcentral.proquest.com/lib/vuw/detail.action?docID=170673.

Wright, Michael, Joelle Dally, and Anna Turner. 'Protester Arrested at Cranmer Courts Demolition'. Stuff.Co.Nz, 4 October 2012, sec. Christchurch Earthquake 2011. http://www.stuff.co.nz/the-press/news/christchurch-earthquake2011/7766034/Protester-arrested-at-Cranmer-Courts-demolition.

Wu, Zongjie, and Song Hou. 'Heritage and Discourse'. In The Palgrave Handbook of Contemporary Heritage Research, edited by Emma Waterton and Steve Watson. London: Palgrave Macmillan UK, 2015. https://doi.org/10.1057/9781137293565. 


\section{Appendices}

\subsection{Timeline of events}

\begin{tabular}{|c|c|c|}
\hline Date & General developments & Town Hall developments \\
\hline 22 February 2011 & $\begin{array}{l}\text { February } 2011 \text { Earthquake. } \\
\text { Wide spread damage. } \\
\text { Central city 'red zone' cordon } \\
\text { created. }\end{array}$ & $\begin{array}{l}\text { Town Hall within red zone } \\
\text { cordon. }\end{array}$ \\
\hline March 2011 & $\begin{array}{l}\text { IConIC develops through local } \\
\text { networks, attempts to advocate for } \\
\text { existing heritage in Christchurch } \\
\text { throughout } 2011 \text { and onwards. }\end{array}$ & \\
\hline 29 March 2011 & CERA created. & \\
\hline 19 April 2011 & $\begin{array}{l}\text { CER Act commences; requires } \\
\text { CCC to develop draft city plan } \\
\text { within } 9 \text { months. }\end{array}$ & \\
\hline May-June 2011 & Share an Idea engagement program. & \\
\hline June 2011 & $\begin{array}{l}\text { Roger Sutton commences as CERA } \\
\text { CEO. }\end{array}$ & \\
\hline 11 August 2011 & $\begin{array}{l}\text { CCC's draft Central City Recovery } \\
\text { Plan (CCP) put out for public } \\
\text { feedback through the 'Tell us what } \\
\text { you think' campaign. }\end{array}$ & \\
\hline August 2011 & & $\begin{array}{l}\text { Holmes Consulting Group } \\
\text { assess Town Hall damage. }\end{array}$ \\
\hline $\begin{array}{l}15 \text { December } \\
2011\end{array}$ & $\begin{array}{l}\text { CCC adopted the revised draft CCP } \\
\text { - sent to minister for consideration. }\end{array}$ & \\
\hline 20 March 2012 & & $\begin{array}{l}\text { Lochhead's opinion piece } \\
\text { appears in The Press - 'Let our } \\
\text { public living room live again' } \\
\text { (first use of the phrase 'public } \\
\text { living room'). }\end{array}$ \\
\hline 18 April 2012 & $\begin{array}{l}\text { Minister largely rejected CCP; set } \\
\text { up CCDU within CERA; } 100 \text { days } \\
\text { to re-write plan. }\end{array}$ & \\
\hline $\begin{array}{l}20 \text { April } 2012- \\
21 \text { May } 2012\end{array}$ & $\begin{array}{l}\text { Public consultation on CCC Draft } \\
\text { Annual Plan 2012/13, including } \\
\text { major community facilities options. }\end{array}$ & $\begin{array}{l}\text { Options for Town Hall include } \\
\text { demolition and partial } \\
\text { demolition. }\end{array}$ \\
\hline
\end{tabular}




\begin{tabular}{|c|c|c|}
\hline May 2012 & $\begin{array}{l}\text { 'Transitional family' people } \\
\text { 'suddenly' decide to run FESTA on } \\
\text { Labour weekend. }\end{array}$ & \\
\hline 25 June 2012 & & $\begin{array}{l}\text { Town Hall debated before } \\
\text { Council, including a move to } \\
\text { demolish and rebuild on a new } \\
\text { site. }\end{array}$ \\
\hline 26 June 2012 & $\begin{array}{l}\text { CCC Annual Plan 2012/13 adopted } \\
\text { (note there was no LTP review in } \\
2012 \text { ). }\end{array}$ & $\begin{array}{l}\text { CCC Annual Plan 2012/13 } \\
\text { budgeted } \$ 127.5 \text { million to } \\
\text { rebuild Town Hall and 'staff } \\
\text { were asked to evaluate the } \\
\text { merits of retaining the main } \\
\text { auditorium and developing a } \\
\text { new entrance and gathering } \\
\text { space provided overall acoustic } \\
\text { quality and sense of place can } \\
\text { be retained.' }\end{array}$ \\
\hline 30 July 2012 & $\begin{array}{l}\text { New CCRP ('the Blueprint') } \\
\text { released; comes into law on } 31 \\
\text { July. }\end{array}$ & $\begin{array}{l}\text { Town Hall excluded from } \\
\text { CCRP. }\end{array}$ \\
\hline $\begin{array}{l}18 \text { September } \\
2012\end{array}$ & & $\begin{array}{l}\text { Date on the letter KOTH sent } \\
\text { to supporters. }\end{array}$ \\
\hline $\begin{array}{l}19 \text { September } \\
2012\end{array}$ & $\begin{array}{l}\text { '100 Days to Rebuild Democracy' } \\
\text { Rally }\end{array}$ & \\
\hline $\begin{array}{l}\text { September - } \\
\text { October } 2012\end{array}$ & & $\begin{array}{l}\text { Most KOTH support letters } \\
\text { sent. }\end{array}$ \\
\hline $\begin{array}{l}20-28 \text { October } \\
2012\end{array}$ & First FESTA (LUX City) & \\
\hline 30 October 2012 & & $\begin{array}{l}\text { Deputations to Community, } \\
\text { Recreation and Culture } \\
\text { Committee on the Town Hall, } \\
\text { including KOTH. }\end{array}$ \\
\hline $\begin{array}{l}14 \text { November } \\
2012\end{array}$ & & $\begin{array}{l}\text { Minister Brownlee disparages } \\
\text { the Town Hall on NewsTalkZB }\end{array}$ \\
\hline $\begin{array}{l}15 \text { November } \\
2012\end{array}$ & & $\begin{array}{l}\text { Barnaby Bennett responds to } \\
\text { Minister Brownlee online. }\end{array}$ \\
\hline $\begin{array}{l}22 \text { November } \\
2012\end{array}$ & & $\begin{array}{l}\text { Deputations to the Council on } \\
\text { the Town Hall, including } \\
\text { KOTH. }\end{array}$ \\
\hline
\end{tabular}




\begin{tabular}{|c|c|c|}
\hline & & $\begin{array}{l}\text { Council votes to retain the } \\
\text { Town Hall ( } 1^{\text {st }} \text { vote). (There is } \\
\text { no business plan at this stage). }\end{array}$ \\
\hline 5 December 2012 & & $\begin{array}{l}\text { Barnaby Bennett makes an } \\
\text { OIA request to CERA } \\
\text { regarding the Town Hall. }\end{array}$ \\
\hline 28 February 2013 & & $\begin{array}{l}\text { CERA response to Bennett's } \\
\text { OIA request. }\end{array}$ \\
\hline March 2013 & $\begin{array}{l}\text { CCC consults on the Three-Year } \\
\text { Plan 2013-16. }\end{array}$ & $\begin{array}{l}\text { KOTH emails supporters } \\
\text { again. }\end{array}$ \\
\hline 21 June 2013 & & $\begin{array}{l}\text { Bennett's 'This isn't about the } \\
\text { Christchurch Town Hall' } \\
\text { article. }\end{array}$ \\
\hline 27 June 2013 & $\begin{array}{l}\text { Cost Sharing Agreement between } \\
\text { CCC and the Crown signed. }\end{array}$ & $\begin{array}{l}\text { Council's proposal to save the } \\
\text { Town Hall results in CCC } \\
\text { leading the development of a } \\
\text { Performing Arts Precinct } \\
\text { (PAP). }\end{array}$ \\
\hline 28 June 2013 & $\begin{array}{l}\text { CCC adopts the Three-Year Plan } \\
\text { 2013-16. }\end{array}$ & \\
\hline 30 June 2013 & $\begin{array}{l}\text { Final removal of the central city red } \\
\text { zone cordon. }\end{array}$ & \\
\hline 8 July 2013 & $\begin{array}{l}\text { A government Crown Manager is } \\
\text { appointed to manage CCC's } \\
\text { building consent crisis. }\end{array}$ & \\
\hline $\begin{array}{l}\text { mid-late July or } \\
\text { early August } \\
2013\end{array}$ & & $\begin{array}{l}\text { Staff reports on options for the } \\
\text { Town Hall presented to } \\
\text { Council in a workshop. }\end{array}$ \\
\hline 23 August 2013 & & $\begin{array}{l}\text { Bennett, Miles Warren, and Ian } \\
\text { Lochhead present to Council } \\
\text { Community, Recreation and } \\
\text { Culture Committee. }\end{array}$ \\
\hline 27 August 2013 & & $\begin{array}{l}\text { Letter sent to KOTH supporter } \\
\text { and published on Project } \\
\text { Freerange. }\end{array}$ \\
\hline 28 August 2013 & & $\begin{array}{l}\text { Media tour of Town Hall - } \\
\text { CCC publishes video on } \\
\text { YouTube on } 1 \text { September } \\
2018 .\end{array}$ \\
\hline
\end{tabular}




\begin{tabular}{|c|c|c|}
\hline 29 August 2013 & & $\begin{array}{l}\text { Barnaby, Jess, and Warren and } \\
\text { Mahoney make deputations to } \\
\text { the Council. } \\
\text { Council votes to fully } \\
\text { refurbish the Town Hall ( } 2^{\text {nd }} \\
\text { vote). }\end{array}$ \\
\hline 24 October 2013 & $\begin{array}{l}\text { Local government elections - } \\
\text { Lianne Dalziel becomes mayor, } \\
\text { only four out of thirteen councillors } \\
\text { are re-elected. }\end{array}$ & \\
\hline $\begin{array}{l}26-27 \text { October } \\
2013\end{array}$ & Second FESTA (Canterbury Tales) & \\
\hline November 2013 & & $\begin{array}{l}\text { Plans for the Town Hall } \\
\text { released; public consultation } \\
\text { workshops. }\end{array}$ \\
\hline May 2014 & $\begin{array}{l}\text { CCC review shows } \$ 500 \text { million } \\
\text { funding shortfall. }\end{array}$ & \\
\hline 9 July 2014 & & $\begin{array}{l}\text { Restoration of Town Hall on } \\
\text { hold due to financial issues - } \\
\text { 'council was waiting to clarify } \\
\text { its insurance position before } \\
\text { proceeding.' }\end{array}$ \\
\hline $\begin{array}{l}12 \text { September - } 7 \\
\text { October } 2014\end{array}$ & & $\begin{array}{l}\text { Expressions of interest period } \\
\text { for Town Hall restoration. }\end{array}$ \\
\hline October 2014 & Third FESTA & \\
\hline November 2014 & $\begin{array}{l}\text { Roger Sutton resigns as CERA } \\
\text { CEO after misconduct. }\end{array}$ & \\
\hline $\begin{array}{l}17 \text { March }-28 \\
\text { April } 2015\end{array}$ & $\begin{array}{l}\text { Public consultation on CCC Long- } \\
\text { Term Plan 2015-2025 Consultation } \\
\text { Document }\end{array}$ & \\
\hline 10 June 2015 & & $\begin{array}{l}\text { Public depositions on Town } \\
\text { Hall. }\end{array}$ \\
\hline 11 June 2015 & & $\begin{array}{l}\text { Presentation of the Town Hall } \\
\text { business plan and Council } \\
\text { debate; Council votes to } \\
\text { restore the Town Hall ( } 3^{\text {rd }} \\
\text { vote). }\end{array}$ \\
\hline 26 June 2015 & $\begin{array}{l}\text { CCC adopt the final Long-Term } \\
\text { Plan 2015-25 }\end{array}$ & \\
\hline 12 June 2015 & & $\begin{array}{l}\text { CCC publishes 'Christchurch } \\
\text { Town Hall restoration }\end{array}$ \\
\hline
\end{tabular}




\begin{tabular}{|c|c|c|}
\hline & & $\begin{array}{l}\text { progress' one year one } \\
\text { promotional video on } \\
\text { YouTube. }\end{array}$ \\
\hline 18 April 2016 & $\begin{array}{l}\text { CERA disestablished (end of five- } \\
\text { year life) - responsibilities } \\
\text { dispersed to a number of different } \\
\text { agencies. }\end{array}$ & \\
\hline 7 October 2016 & & $\begin{array}{l}\text { Town Hall restorations 'near } \\
\text { half way point' - Warren and } \\
\text { Mahoney conduct tour of the } \\
\text { complex. }\end{array}$ \\
\hline 8 October 2016 & $\begin{array}{l}\text { Local elections conclude - Lianne } \\
\text { Dalziel returned as mayor. }\end{array}$ & \\
\hline October 2016 & $\begin{array}{l}\text { Fourth FESTA (Sustainability); } \\
\text { includes 'Lost Christchurch' }\end{array}$ & \\
\hline 24 April 2017 & $\begin{array}{l}\text { Cabinet reshuffle; Nicky Wagner } \\
\text { replaces Gerry Brownlee as } \\
\text { Earthquake Minister. }\end{array}$ & \\
\hline 29 June 2017 & & $\begin{array}{l}\text { Christ's College band play in } \\
\text { auditorium for public and } \\
\text { Council. }\end{array}$ \\
\hline August 2017 & & $\begin{array}{l}\text { Expected completion date } \\
\text { pushed to } 2019 .\end{array}$ \\
\hline February 2018 & & $\begin{array}{l}\text { Town Hall restoration budget } \\
\text { risen to } \$ 140.6 \text { million. }\end{array}$ \\
\hline 2019 & & $\begin{array}{l}\text { Christchurch Town Hall } \\
\text { expected to re-open. }\end{array}$ \\
\hline
\end{tabular}




\subsection{Deputations to CCC}

Table 1: Deputations to CCC regarding the Town Hall, 2012-2015

\section{Date}

30 October 2012

2012

23 August 2013

29 August 2013

10 June 2015

\section{Deputation to}

Community, Recreation, and Culture Committee

Christchurch City Council
Sir Miles Warren
Jessica Halliday
Ian Lochhead
Sir Harold Marshall
Barnaby Bennett
Miles Warren
Ian Lochhead

\section{Deputation by}

David Towns and Pete Barton (Friends of the Town Hall Organ) Jessica Halliday for KOTH
Community, Recreation and Culture Committee

Christchurch City Council

Barnaby Bennett

Luke di Somma

(Conductor/composer/theatre producer)

Jessica Halliday

Neil Cox (Isaac Theatre Royal)

Gretchen La Roche (Christchurch

Symphony Orchestra)

Sir Miles Warren and Maurice Mahoney.

Christchurch City Council

Don Whelan (representing music

teachers)

Ian Lochhead for Historic Places

Canterbury and KOTH

Martin Setchell (Town Hall organ

curator)

Graeme Wallis and Margaret Austin

(Voice Christchurch)

Sir Miles Warren and Maurice Mahoney

Jessica Halliday

11 June 2015

Christchurch City Council
Helen Broughton (former CCC

Councillor) 


\section{$8.3 \quad$ List of support letters}

\begin{tabular}{|c|c|c|c|c|}
\hline & Letter by & Co-signed by & $\begin{array}{l}\text { Organisation (if } \\
\text { any) }\end{array}$ & $\begin{array}{l}\text { Profession/Position } \\
\text { (if stated) }\end{array}$ \\
\hline 1 & $\begin{array}{l}\text { Dame Kiri Te } \\
\text { Kanawa }\end{array}$ & & & Singer \\
\hline 2 & Barry Bergdoll & & $\begin{array}{l}\text { The Museum of } \\
\text { Modern Art }\end{array}$ & $\begin{array}{l}\text { The Philip Johnson } \\
\text { Chief Curator of } \\
\text { Architecture and } \\
\text { Design }\end{array}$ \\
\hline 3 & $\begin{array}{l}\text { Dame Gillian } \\
\text { Weir }\end{array}$ & & & Organist \\
\hline 4 & Fran Ricketts & & $\begin{array}{l}\text { The Arts } \\
\text { Foundation }\end{array}$ & Chairperson \\
\hline 5 & $\begin{array}{l}\text { Professor Paul } \\
\text { Walker }\end{array}$ & & $\begin{array}{l}\text { The University of } \\
\text { Melbourne }\end{array}$ & $\begin{array}{l}\text { Professor of } \\
\text { Architecture }\end{array}$ \\
\hline 6 & Dr Julia Gatley & & Docomomo NZ & \\
\hline 7 & $\begin{array}{l}\text { Associate } \\
\text { Professor } \\
\text { Hannah Lewi }\end{array}$ & $\begin{array}{l}\text { Buildings at Risk sub- } \\
\text { committee }\end{array}$ & $\begin{array}{l}\text { Docomomo } \\
\text { Australia }\end{array}$ & \\
\hline 8 & David Sheppard & & NZIA & $\begin{array}{l}\text { President } \\
\text { (Architect) }\end{array}$ \\
\hline 9 & David Hill & & NZIA & $\begin{array}{l}\text { Chairman of NZIA } \\
\text { Canterbury Branch } \\
\text { (Architect) }\end{array}$ \\
\hline 10 & $\begin{array}{l}\text { Associate } \\
\text { Professor Tony } \\
\text { van Raat }\end{array}$ & $\begin{array}{l}\text { Ass. Prof Christoph } \\
\text { Schnoor; } \\
\text { Snr. Lecturer Chris } \\
\text { Murphy; } \\
\text { Snr. Lecturer John } \\
\text { Hewitt; } \\
\text { Lecturer Peter } \\
\text { McPherson; } \\
\text { Lecturer Krystina Kaza; } \\
\text { Snr. Lecturer David } \\
\text { Turner; } \\
\text { Lecturer Ainsley } \\
\text { O'Connell; } \\
\text { Snr. Lecturer Jeanette } \\
\text { Budgett; } \\
\text { Lecturer David } \\
\text { Chaplin; }\end{array}$ & $\begin{array}{l}\text { Unitec Institute of } \\
\text { Technology }\end{array}$ & $\begin{array}{l}\text { Head of } \\
\text { Architecture at } \\
\text { Unitec }\end{array}$ \\
\hline
\end{tabular}




\begin{tabular}{|c|c|c|c|c|}
\hline & & $\begin{array}{l}\text { Professor Su Bin; } \\
\text { Lecturer Kerry Francis; } \\
\text { Snr. Lecturer Graeme } \\
\text { McConchie; } \\
\text { Professor Mike Austin; } \\
\text { Ass. Prof. Dushko } \\
\text { Bogunovich; } \\
\text { Lecturer Mark } \\
\text { Mismash; } \\
\text { Lecturer Lester } \\
\text { Mismash; Lecturer Max } \\
\text { Hynds; } \\
\text { Ass Prof. Regan } \\
\text { Potangaroa; } \\
\text { and } 127 \text { architecture } \\
\text { students }\end{array}$ & & \\
\hline 11 & Ian Athfield & & $\begin{array}{l}\text { Athfield } \\
\text { Architects Limited }\end{array}$ & Director (Architect) \\
\hline 12 & $\begin{array}{l}\text { Professor } \\
\text { Jonathan Mane- } \\
\text { Wheoki }\end{array}$ & & $\begin{array}{l}\text { Elam School of } \\
\text { Fine Arts, The } \\
\text { University of } \\
\text { Auckland }\end{array}$ & $\begin{array}{l}\text { Professor of Fine } \\
\text { Arts }\end{array}$ \\
\hline 13 & Neil Roberts & & $\begin{array}{l}\text { Christchurch } \\
\text { Civic Trust }\end{array}$ & Chairman \\
\hline 14 & Mark Gerrard & Lynne Lochhead & $\begin{array}{l}\text { Historic Places } \\
\text { Canterbury }\end{array}$ & \\
\hline 15 & $\begin{array}{l}\text { Christine } \\
\text { McCarthy }\end{array}$ & & $\begin{array}{l}\text { The Architecture } \\
\text { Centre inc. }\end{array}$ & $\begin{array}{l}\text { President } \\
\text { (Architect) }\end{array}$ \\
\hline 16 & Shelley Penn & & $\begin{array}{l}\text { Australian } \\
\text { Institute of } \\
\text { Architects; } \\
\text { National Capital } \\
\text { Authority }\end{array}$ & Architect \\
\hline 17 & Gordon Moller & & Moller Architects & Architect \\
\hline 18 & Patrick Clifford & & & Architect \\
\hline 19 & $\begin{array}{l}\text { Maurice } \\
\text { Mahoney }\end{array}$ & & & Architect \\
\hline 20 & $\begin{array}{l}\text { Barnaby } \\
\text { Bennett }\end{array}$ & & KOTH & Architect \\
\hline
\end{tabular}




\begin{tabular}{|c|c|c|c|}
\hline 21 & $\begin{array}{l}\text { Associate } \\
\text { Professor Ian } \\
\text { Lochhead }\end{array}$ & $\begin{array}{l}\text { Unicersity of } \\
\text { Canterbury } \\
\text { College of Arts; } \\
\text { KOTH }\end{array}$ & $\begin{array}{l}\text { Associate Professor } \\
\text { of Art History }\end{array}$ \\
\hline 22 & Duncan Craig & & Architect \\
\hline 23 & $\begin{array}{l}\text { Sir Michael } \\
\text { Fowler }\end{array}$ & $\begin{array}{l}\text { Michael Fowler } \\
\text { Gallery }\end{array}$ & Architect \\
\hline 24 & $\begin{array}{l}\text { William } \\
\text { Toomath }\end{array}$ & & Architect \\
\hline 25 & $\begin{array}{l}\text { Don } \\
\text { Donnithorne }\end{array}$ & $\begin{array}{l}\text { Don Donnithorne } \\
\text { Architects Ltd }\end{array}$ & Architect \\
\hline 26 & $\begin{array}{l}\text { Linley } \\
\text { Hindmarsh }\end{array}$ & $\begin{array}{l}\text { Greer Hindmarch } \\
\text { Architects }\end{array}$ & Director (Architect) \\
\hline 27 & Richard Dalman & Dalman Architects & $\begin{array}{l}\text { Managing Director } \\
\text { (Architect) }\end{array}$ \\
\hline 28 & Bop Simpson & $\begin{array}{l}\text { Simpson } \\
\text { Architects }\end{array}$ & Architect \\
\hline 29 & Stephen Crooks & & Architect \\
\hline 30 & $\begin{array}{l}\text { Justin } \\
\text { Leadbetter }\end{array}$ & $\begin{array}{l}\text { Leadbetter Carr } \\
\text { Ltd }\end{array}$ & Director (Architect) \\
\hline 31 & Ed Coomber & & $\begin{array}{l}\text { Architectural } \\
\text { Designer }\end{array}$ \\
\hline 32 & $\begin{array}{l}\text { Brendon } \\
\text { Haughey }\end{array}$ & & $\begin{array}{l}\text { Architectural } \\
\text { Designer }\end{array}$ \\
\hline 33 & $\begin{array}{l}\text { Christina } \\
\text { Mckay }\end{array}$ & $\begin{array}{l}\text { Victoria } \\
\text { University of } \\
\text { Wellington }\end{array}$ & $\begin{array}{l}\text { Senior Lecturer in } \\
\text { Interior } \\
\text { Architecture }\end{array}$ \\
\hline 34 & $\begin{array}{l}\text { Sir William } \\
\text { Southgate }\end{array}$ & & Conductor \\
\hline 35 & Patricia Payne & & Opera Singer \\
\hline 36 & $\begin{array}{l}\text { Wendelin } \\
\text { Eberle }\end{array}$ & Rieger-Orgelbau & President \\
\hline 37 & Martin Setchell & $\begin{array}{l}\text { Friends of the } \\
\text { Christchurch } \\
\text { Town Hall Organ } \\
\text { Trust }\end{array}$ & $\begin{array}{l}\text { Town Hall Organ } \\
\text { Curator }\end{array}$ \\
\hline 38 & Brian Law & & $\begin{array}{l}\text { Director of Music } \\
\text { Christchurch } \\
\text { Cathedral; Director } \\
\text { of Music }\end{array}$ \\
\hline
\end{tabular}




\begin{tabular}{|c|c|c|c|c|}
\hline & & & & $\begin{array}{l}\text { Christchurch City } \\
\text { Choir }\end{array}$ \\
\hline 39 & $\begin{array}{l}\text { Associate } \\
\text { Professor Dr } \\
\text { Karen Grylls }\end{array}$ & & $\begin{array}{l}\text { New Zealand } \\
\text { Youth Choir }\end{array}$ & Artistic Director \\
\hline 40 & Marc Taddei & & $\begin{array}{l}\text { Wellington } \\
\text { Orchestra }\end{array}$ & Music Director \\
\hline 41 & Thomas Trotter & & & Organist \\
\hline 42 & Robert Ampt & & & $\begin{array}{l}\text { Sydney City } \\
\text { Organist }\end{array}$ \\
\hline 43 & $\begin{array}{l}\text { Professor } \\
\text { Michael Endres }\end{array}$ & & $\begin{array}{l}\text { University of } \\
\text { Canterbury }\end{array}$ & \\
\hline 44 & Diedre Irons & & & \\
\hline 45 & Leo Beranek & & & Acoustician \\
\hline 46 & John Bradley & & $\begin{array}{l}\text { National Research } \\
\text { Council Canada, } \\
\text { Institute for } \\
\text { Research in } \\
\text { Construction }\end{array}$ & \\
\hline 47 & Eckhard Kahle & & Kahle Acoustics & Director \\
\hline 48 & Hugo Zanker & & & Cellist \\
\hline 49 & W Laird & & Atoll Records & Producer \\
\hline 50 & Amiria Grenell & $\begin{array}{l}\text { Redford Grenell } \\
\text { Oakley Grenell } \\
\text { Denver Grenell } \\
\text { John Grenell }\end{array}$ & & Musicians \\
\hline 51 & Samuel Scott & & $\begin{array}{l}\text { The Phoenix } \\
\text { Foundation (band) }\end{array}$ & $\begin{array}{l}\text { Musician, } \\
\text { Composer }\end{array}$ \\
\hline 52 & Luke Buda & & $\begin{array}{l}\text { The Phoenix } \\
\text { Foundation (band) }\end{array}$ & Musician \\
\hline 53 & Peter Cropper & & & \\
\hline 54 & $\begin{array}{l}\text { Annabel } \\
\text { Cropper }\end{array}$ & & & \\
\hline 55 & $\begin{array}{l}\text { Katherine } \\
\text { Bennetts }\end{array}$ & & & \\
\hline 56 & Grant Scott & & & Architect \\
\hline 57 & Tim McJorrow & & St Mark's School & Principal \\
\hline 58 & Robin Yates & Scott Yates & & \\
\hline 59 & Richard Donald & Gennie Donald & & \\
\hline
\end{tabular}




\subsection{Submissions to CCC Plans on the Christchurch Town Hall}

Table 2: Town Hall options and financials presented in the 2015 CCC Business Case

\begin{tabular}{|l|l|l|l|}
\hline Option & Cost (millions) & $\begin{array}{l}\text { Insurance pay- } \\
\text { out (millions) }\end{array}$ & $\begin{array}{l}\text { Cost to CCC } \\
\text { (millions) }\end{array}$ \\
\hline Do nothing & $\begin{array}{l}\$ 12 \text { million } \\
\text { (includes costs to } \\
\text { date of } \$ 7 \text { million) }\end{array}$ & $\$ 32$ & $\begin{array}{l}\text { CCC receives } \\
\$ 19\end{array}$ \\
\hline $\begin{array}{l}\text { Build new 1500 seat auditorium } \\
\text { and 600 seat theatre on a new } \\
\text { site (the Blueprint option) }\end{array}$ & $\begin{array}{l}\$ 193.5 \\
\text { plus site costs }\end{array}$ & $\$ 32$ & $\$ 166$ \\
\hline Repair auditorium and foyer & $\$ 91$ & $\$ 53$ & $\$ 39$ \\
\hline $\begin{array}{l}\text { Repair auditorium, foyer and } \\
\text { James Hay }\end{array}$ & $\$ 109$ & $\$ 62$ & $\$ 47$ \\
\hline $\begin{array}{l}\text { Full restoration (target 100\% } \\
\text { NBS) }\end{array}$ & $\$ 127.6$ & $\$ 69$ & $\$ 58.6$ \\
\hline
\end{tabular}

Table 3: Opinions on the Town Hall in submissions to the CCC draft Annual Plan 2012/13

\begin{tabular}{|l|l|l|}
\hline Option & Count & Percentage \\
\hline Unclear/no opinion & 20 & $33 \%$ \\
\hline Rebuild to 100\% & 12 & $20 \%$ \\
\hline Rebuild like-to-like & 1 & $2 \%$ \\
\hline Build new & 15 & $25 \%$ \\
\hline Demolish Limes and Cambridge room & 4 & $7 \%$ \\
\hline Rebuild with amendments & 7 & $11 \%$ \\
\hline Only repair auditorium and build new foyer. & 1 & $2 \%$ \\
\hline Demolish and don't rebuild & 1 & $2 \%$ \\
\hline Grand Total & 61 & $100 \%$ \\
\hline
\end{tabular}

CCC received 2673 submissions on the draft Annual Plan 2012-2013 draft.

Table 4: Analysis of submissions on the Town Hall to the Long-Term Plan 2015-25

\begin{tabular}{|l|l|l|}
\hline Option & Count & Percentage \\
\hline Delay/demolish/do nothing & 24 & $43 \%$ \\
\hline Rebuild new & 3 & $5 \%$ \\
\hline Restore & 9 & $16 \%$ \\
\hline Restore auditorium only & 8 & $14 \%$ \\
\hline Restore auditorium or all & 2 & $4 \%$ \\
\hline Unclear & 8 & $14 \%$ \\
\hline
\end{tabular}

CCC received 2997 submissions on the draft Long-Term Plan 2015-2025 draft. 